\title{
The Other Figure in the Carpet: \\ Narrative Voice as an Indicator of Bourdieuian \\ Heteronomy in Henry James's The Ambassadors \\ by
}

\section{Aaron Donachuk}

A thesis submitted to the Faculty of Graduate and Postdoctoral Affairs

in partial fulfillment of the requirements for the degree of

\section{Master of Arts}

Department of English

Carleton Eniversity

Ottawa, Ontario

August 15, 2011

(C) 2011

Aaron Donachuk 
Library and Archives Canada

Published Heritage Branch

395 Wellington Street Ottawa ON K1A ON4 Canada
Bibliotheque et

Archives Canada

Direction du

Patrimoine de l'édition

395 , rue Wellington

Ottawa ON K1A ON4

Canada
Your file Votre référence

ISBN: 978-0-494-83073-4

Our file Notre référence

ISBN: 978-0-494-83073-4
NOTICE:

The author has granted a nonexclusive license allowing Library and Archives Canada to reproduce, publish, archive, preserve, conserve, communicate to the public by telecommunication or on the Internet, loan, distribute and sell theses worldwide, for commercial or noncommercial purposes, in microform, paper, electronic and/or any other formats.

The author retains copyright ownership and moral rights in this thesis. Neither the thesis nor substantial extracts from it may be printed or otherwise reproduced without the author's permission.
AVIS:

L'auteur a accordé une licence non exclusive permettant à la Bibliothèque et Archives Canada de reproduire, publier, archiver, sauvegarder, conserver, transmettre au public par télécommunication ou par l'Internet, prêter, distribuer et vendre des thèses partout dans le monde, à des fins commerciales ou autres, sur support microforme, papier, électronique et/ou autres formats.

L'auteur conserve la propriété du droit d'auteur et des droits moraux qui protège cette thèse. $\mathrm{Ni}$ la thèse ni des extraits substantiels de celle-ci ne doivent être imprimés ou autrement reproduits sans son autorisation.
In compliance with the Canadian Privacy Act some supporting forms may have been removed from this thesis.

While these forms may be included in the document page count, their removal does not represent any loss of content from the thesis.
Conformément à la loi canadienne sur la protection de la vie privée, quelques formulaires secondaires ont été enlevés de cette thèse.

Bien que ces formulaires aient inclus dans la pagination, il n'y aura aucun contenu manquant. 


\begin{abstract}
The thesis uses a bipartite methodology that combines Gérard Genette's narratological paradigm and Pierre Bourdieu's concept of cultural fields to offer a new reading of narrative voice in Henry James's The Ambassadors. It uses Bourdieu to position James within the literary field of late-nineteenth-century Britain. It locates the author in a position between the autonomous pole that signals "art for art's sake" and the heteronomous pole that is associated with established bourgeois values. It identifies James's autonomy and heteronomy at the textual level with Genette's concepts of narrative mood and voice, respectively. It thus illustrates the contextual significance of these narratological elements by identifying them as functions of the literary field. Whereas theorists since Genette have emphasized mood in James by ignoring these contextual factors, the thesis provides a revisionary reading that illustrates the importance of narrative voice within the textual economy of The Ambassadors by using this contextsensitive approach.
\end{abstract}




\section{Acknowledgments}

I would like to thank my professors at Carleton University - Professors Paul Keen, Travis DeCook, Andrew Wallace, and Janice Schroeder - for introducing me to many of the concepts that have been employed in this thesis. I would also like to acknowledge the outgoing English Graduate Supervisor at Carleton University, Professor Grant Williams, who helped facilitate this project when it was in its nascent stages. I am grateful to my thesis supervisor, Professor Barbara Leckie, for agreeing to supervise the project and for providing considerate guidance throughout the writing and revision stages. Finally, I would like to thank my partner Laura Hildebrand for being so encouraging. 


\section{Contents}

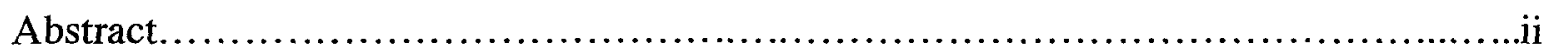

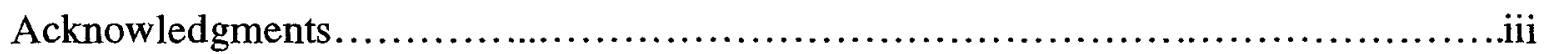

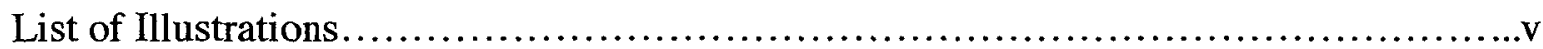

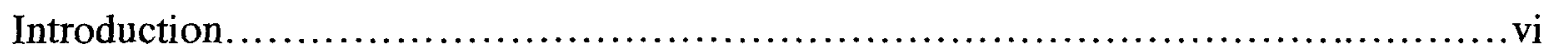

Chapter 1: Grasping the Thread: Toward an Elucidation of the Spatio-Temporal

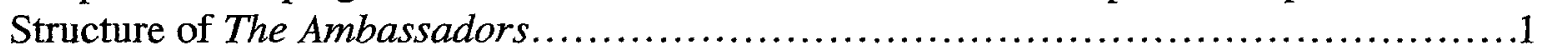

Chapter 2: The Dueling Dispositions of Late James and the Clinical Construction of

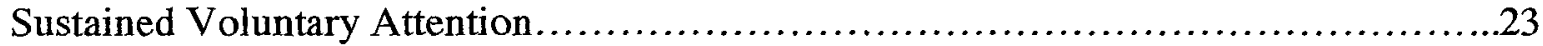

Chapter 3: Viva Voce, In Situ.....................................................57

Chapter 4: Saving the Present; or, Voice Per Se...................................86

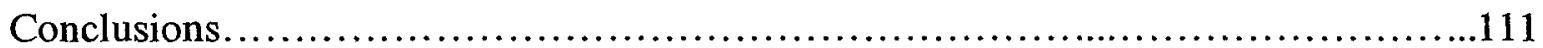

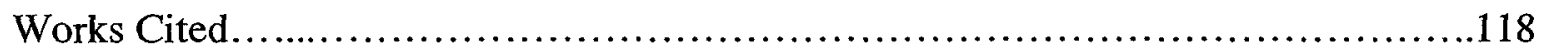




\section{List of Illustrations}

Figure 1: French Literary Field in the Second Half of the Nineteenth Century ........... 26

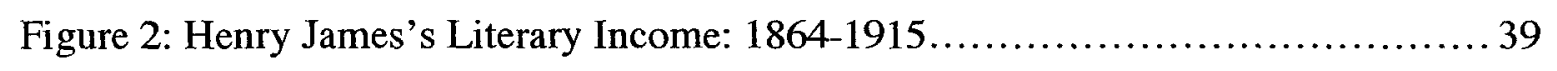




\section{Introduction}

This thesis will conduct a socio-narratological reading of Henry James's The Ambassadors. It will analyze narrative voice by situating the text in the contextualizing frame of the turn-of-the-century British literary field. It will consider voice as the textual trace of a narrato-authorial subject - the author's textual surrogate. This trace will be described using Gérard Genette's narratological paradigm, and will be represented by the image of a thread stretched through the entire span of the narrative text. Using the socionarratological schema, it will figure the vocal thread as signifying the author's attempts to achieve bourgeois consecration according to Pierre Bourdieu's heteronomous principle. On the other hand, as a non-authorial entity that also structures the textual whole, the text's focalizing subject will be identified as the textual representative of James's struggles for autonomous (or purely artistic) consecration within the literary field. It will be argued that by structuring the text on the basis of these two subjectivities - one authorial and the other non-authorial - James attempted to achieve both heteronomous and autonomous consecration with the same narrative text. But due to a number of factors, including the stringent late-nineteenth-century requirements of the autonomous principle and the politics of twentieth-century Anglo-American and French narrative theory, the heteronomous authorial trace was both originally obscured by James and subsequently ignored by theorists. And while The Ambassadors is structured on these two bases, because so much work has already been done to describe the structuring element that is associated with the text's focalizing character (that is, under the headings of "point of view" and "perspective"), the purpose of the current thesis will be to 
highlight and explicate the dissimulated and under-analyzed vocal component of James's narrative text.

Shlomith Rimmon describes an image that represents the approach that will be taken in this thesis. Rimmon prefaces her book on ambiguity in James with an image of an image - an image, in fact, of two co-present, mutually exclusive images - which she uses to illustrate the concept of literary ambiguity. Rimmon writes,

There are visual tricks that constantly tease the eye and never let our interpretative faculty come to rest. A slight shift of perspective can turn a rabbit into a duck, an urn into two profiles, a group of white birds flying in one direction into a group of black birds flying in the other. How is an image capable of representing different objects at the same time, and what happens to our minds while watching it? (ix) Rimmon continues on to argue that some of Henry James's texts elicit a similar image. That is, they present to the reader two mutually exclusive, yet equitenable, interpretations, and are thus ambiguous in the strictest sense. But rather than attempt to resolve or ameliorate this ambiguity and identify the lone, "most true" interpretation of her chosen Jamesian texts, Rimmon develops a methodology that works to hypostasize ambiguity. As such, her schema serves as a means of settling questions that have persistently nagged Jamesian critics in the past, such as whether the ghosts in The Turn of the Screw are "real" or products of the governess's disturbed psyche. If one reads these Jamesian texts within the frame of Rimmon's methodology, both accounts are true, and the narrative is thus truly ambiguous. And when Rimmon illustrates, in the course of developing her methodology, what it means to put a particular textual proposition into an interpretative context, she once again reverts to the duck-rabbit image: "To use an 
analogy from the visual arts: it is equally likely that if we draw a duck pond or a rabbit warren around Gombrich's rabbit-or-duck figure, that figure will be grasped unambiguously as either a rabbit or a duck, depending on the visual context in which it appears" (60). While Rimmon uses this image to refer to the narratological contextualization of one of the text's sentences or propositions, the metaphor could be extended to describe her work as a whole: in the first (primarily methodological) half of her book, Rimmon cobbles together a hybrid "warren-pond" schema so that in the second half she can place the Jamesian text within this theoretical context, thereby allowing the texts' two mutually exclusive yet co-present interpretations to thrive in an environment hospitable to both.

This thesis will be patterned on the same dichotomous model that balances the development of an interpretative context with the analysis of an object text. But rather than create an hospitable climate in which the text's ambiguities may flourish, the first half of this two-part thesis will set up a context in which two of the text's narratological aspects may appear with equal prominence. These two aspects are what Gérard Grenette refers to as narrative mood and narrative voice. The critical and theoretical inclination to analyze James's works primarily in reference to the concept of point of view is well documented. ${ }^{1}$ Indeed, the scholarly communities that congregated around the Jamesian text throughout the twentieth century - the narrative theorists known as the AngloAmerican Jamesians are indicative of this trend - tended to focus on what has been referred to as "restricted point of view" or "limited perspective" as the crux of Jamesian

\footnotetext{
${ }^{1}$ For a succinct summary of this history, see either Basic or Amoros.
} 
scholarship. ${ }^{2}$ It was not until Gerard Genette divided the concept of point of view into two components - allocated into distinct narratological categories of mood and voice that its coherence, and thus its authority as the Eucharist uniting a scholarly community, was undermined. Genette describes his distinction in the following: "to my mind most of the theoretical works on this subject (which are mainly classifications) suffer from a regrettable confusion between mood and voice, a confusion between the question who is the character whose point of view orients the narrative perspective? and the question who is the narrator? - or, more simply, who sees? and the question who speaks?" (Narrative 186, emphasis in the original). ${ }^{3}$ That this distinction was readily accepted, thereby dealing a definitive blow to the Anglo-American tradition, is evoked in the following statement by J. A. A. Amoros: "In 1983 Sonja Basic admitted that the most important amendment suffered by the Jamesian narrative tradition was the conscious separation of speaker and observer" (55). But while this distinction had the negative effect of disturbing the foundation of the Anglo-American school - and arguably crowning, for a time, French structuralist narratology as the reigning paradigm of narrative theory - it did not have the immediate, positive effect of stimulating analyses of the newly-minted concept of narrative voice (not, at least, in the case of The Ambassadors) ${ }^{4}$ Indeed, the Anglo-American concept of narrative perspective, which

\footnotetext{
${ }^{2}$ See Basic (203-210) and Amoros (47).

${ }^{3}$ While this distinction required theoretical elucidation in order to be made apparent, it is somewhat self-evident in What Maisie Knew; James explains the reason for this in the preface to the novel: "even though it is [Maisie's] interest that mainly makes matters interesting for us, we inevitably note this in figures that are not yet at her command" (10). ${ }^{4}$ This occurs in Amoros's essay, in which he recognizes a distinction between mood and voice in James, only to summarily ascribe each aspect to a different ontological realm, a result of which is that mood retains its place in the narrative (or literary realm), while voice is identified as (for lack of a better term) biographical (51).
} 
conflated both the vocal and ocular aspects of narration (and subordinated the latter to the former) was supplanted by Genette's analytic mode that distinguished between these two aspects and identified them as equally important concepts within a single narratological paradigm. But in the case of James's The Ambassadors, the balance of Genette's revised narratological paradigm was not reflected in subsequent academic work, which instead maintained the disproportionate importance of the ocular element to the detriment of the vocal one. 5

The question that this observation prompts is: Why did this innovative understanding of narrative discourse not stimulate a reevaluation of the importance in the Jamesian text of the newly isolated concept of narrative voice? One explanation for this is that the new concept came to be seen as the dross that had to be skimmed from the refined theoretical version of this text in order to reflect the purity of James's contributions to narrative theory. ${ }^{6}$ Accordingly, the concept of what Genette refers to as "fixed internal focalization" - which falls under the category of mood - came to represent the mineable element buried within James's novels, and the concept of voice

\footnotetext{
${ }^{5}$ Gérard Genette has to take some of the blame for this trend, given that in his influential narratological text Narrative Discourse he confines all of his Jamesian references to his chapter on narrative mood and does not refer to James at all in the context of voice. But notwithstanding this unbalanced representation of the Jamesian text, his work as a whole represents these two concepts as bearing an equal importance.

${ }^{6}$ It may also reflect the perceived division between the importance of vision in structuring the Jamesian text (see Agnew, Hutchison, Griffin, Seligson, Tintner, and Rawlings" "Narratives of Theory and Theories of Narrative") and that of style (or voice) in structuring the idiosyncratic Jamesian sentence (see Chatman, Smit).

${ }^{7}$ Gerald Prince defines the term "focalization" by identifying it as the "perspective in terms of which the narrated situations and events are presented; the perceptual or conceptual position in terms of which they are rendered" (31). Prince gives the definition of "fixed internal focalization" in the following: When such a position is locatable (in one character or another) and entails conceptual or perceptual restrictions [...] the narrative is said to have internal focalization [...]. Internal focalization can be fixed (when one and only one perspective is adopted $[\ldots]$ )" (32).
} 
came to be regarded as the impurity that the more advanced techniques of narratological mining and purification were now able to separate from this element. It is not surprising, then, that so many of the studies that followed in the wake of Genette's narratological treatise have focused on refining the concept of narrative focalization. ${ }^{8}$ On the other hand, narratological studies that highlight the importance of voice in James have suffered from the inertia that propels narratology in the direction of this type of purification. ${ }^{9}$ The current thesis will attempt to counteract this inertia through recourse to the previously mentioned bipartite methodology. This methodology will be one that combines the insights of Pierre Bourdieu's theory of literary fields with the narratological mode of analysis promoted in Gérard Genette's Narrative Discourse. In so doing, it will identify the narratological concepts of mood and voice - as they are displayed in James's The Ambassadors - as representative of the autonomous and heteronomous principles, respectively. For Bourdieu, the autonomous principle impels literary producers to compose their works according to purely literary objectives. This principle is most succinctly summarized with the phrase "art for art's sake." The heteronomous principle, by contrast, encourages a composition that accords to standards developed outside the literary field. An example of such a system of standards - and one that Bourdieu uses to explain the concept in the context of the late-twentieth-century French literary field - is the reigning bourgeois code of social values. It is the contention of the current thesis that James's composition of The Ambassadors was influenced by both principles, and that this double influence is inscribed at the level of narrative, with the autonomous principle

\footnotetext{
${ }^{8}$ For examples of such work see Bal and Nieragden.

${ }^{9}$ As has been suggested, this inertia propels narratological analyses in the direction of refining the concept of focalization and reserving voice for stylistic analyses (as demonstrated in Aczel 471).
} 
being aligned with instantiations of narrative mood and the heteronomous principle being signaled by narrative voice. Like Rimmon's methodology, the socio-narratological one that will be developed in the current thesis will serve to highlight the co-existence of these two oppositional aspects of the Jamesian text.

It will pay to look at a particular quotation from Bourdieu's The Field of Cultural Production in order to give a sense of how the Bourdieuian and Genettean paradigms can interact to produce such a reading of The Ambassadors. It has already been stated that narratologists have inadvertently identified the concept of focalization as the autonomous feature of the text by placing so much importance on the continued process of purifying it. Bourdieu expresses the ability of his own methodology to counteract the inclination toward theoretical purification in the following:

The resolutely historicist position which leads one to a rigorous understanding of the historical emergence of transhistorical logic, as in art or science, has as its first effect the extrication of critical discourse from the Platonic temptation to produce essences - of the literary, or the poetic, or, in another domain, of mathematics, etc. The analytical study of essences, of which so many "theoreticians" are guilty (notably with respect to "literariness" [...]), are only re-using, without knowing it, the historical production of the slow and very gradual work of purification $[\ldots]$ which, in each of the genres - poetry, novel, theatre - accompanied the autonomization of the field of production: from purification to purification, the struggles of which the field of production is the site gradually contributed to the isolation of the specific principle of poetic, theatrical, or novelistic effect, leaving 
only a kind of concentrated extract [...] of the properties most apt to produce the effect of the genre under consideration [...]. (190, emphasis in the original) Bourdieu suggests here that literary scholars vied for autonomy within the twentiethcentury academic field by isolating textual features that were emphasized by literary producers in their own struggles for literary autonomy within the late-nineteenth-century literary field. In doing so, these literary academics automatically and unconsciously reenacted past struggles, thereby expressing the principle of "art for art's sake" in the guise of elucidations of, for example, "literariness." By identifying the concept of fixed internal focalization (which falls under the category of narrative mood) as a concept that has been repeatedly purified - and thus one expressive of struggles for autonomy not only in the British literary field of the late-nineteenth century but also in the literary-academic field of the late-twentieth century - this thesis will take advantage of the mood-voice split promulgated by Genette, using narrative voice to designate the heteronomous aspect of James's work while reserving the concept of mood to refer to textual expressions of literary autonomy. Thus, it will counteract the inertia of narratological purification by pairing narratological analysis with a methodology that is inclined to elicit both the autonomous and heteronomous aspects of the Jamesian text.

But while autonomous mood and heteronomous voice represent distinct aspects of the Jamesian text, it is important to recognize that they interact in significant ways in The Ambassadors. It will be one of the contentions of this thesis that the two interact within the context of late-twentieth-century psychological discourses on attention to represent the dynamics of the bi-subjective experimental environment. According to the results of some of the numerous studies on attention that were being conducted at the end 
of the nineteenth century, the notion that a physiological subject is able to willfully maintain its focus on a single topic for an extended period (that it is able to possess sustained voluntary attention) was being discredited. ${ }^{10}$ This was due to the fact that the movements of attention were being shown to function not willfully, and not on a unilinear temporal basis, but automatically, and according to a logic that is better represented with the wave-like motions of the circulo-respiratory system. But as these investigators were challenging the validity of the bourgeois virtue of sustained voluntary attention, they were simultaneously monopolizing this virtue for themselves by way of the inter-subjective dynamic that their experimental environments created. While the attention of the sensorial clinical subject was being shown to waver according to physiological rhythms, the attention of the relatively disembodied and discursive clinician studying these effects was allowed to exist on the unilinear basis of the graphical record of clinical investigation. It will be argued in this thesis that the bisubjective narrative economy that James sets up in The Ambassadors is homologous to this clinical environment, with narrative mood representing the physiological, nonauthorial subject of clinical investigation, and narrative voice representing a narratoauthorial clinician of attenuated physiological existence. And as the vocal thread running through the text is the discursive trace of the latter subject's unilinear attention span, it comes to serve as the textual expression of the endangered (and heteronomous) bourgeois virtue of sustained voluntary attention.

While the thesis will not include a direct study of the relationship between Henry James's fiction and William James's psychological writing, it will suggest a connection

\footnotetext{
${ }^{10}$ See William James (420-21) and Hagner, who writes, "Precisely at this point, attention became a problem" $(680)$.
} 
between these two authors. In this respect, the thesis will build on past work conducted by Judith Ryan. According to Ryan, William James developed his concept of pragmatism in order to give credence to the empiricist notion that the self exists as a loose bundle of sense impressions (which implies a fragmentary subject and the breakdown of the subject-object distinction), while at the same time preserving a more traditional notion of selfhood by emphasizing subjective coherence (13-14). Ryan quotes William's definition of this sensorial, but coherent, self and relates it to Henry James's fiction in the following:

"The individualized self," wrote William James in his Essays in Radical Empiricism, "which I believe to be the only thing properly called self, is a part of the content of the world experienced. The world experienced (otherwise called the 'field of consciousness') comes at all times with our body as its centre, centre of vision, centre of action, centre of interest ... The word ' $I$ ', then, is primarily a noun of position, just like 'this' and 'here'." If any writer can be said to have transformed this view into literature, it is Henry James. (75)

Ryan argues that the focalizing protagonist of The Ambassadors takes the form of William James's individualized self, as this character exists as a bundle of interests and perceptions grouped around a single point of subjective reference. ${ }^{11}$ But while Ryan's argument implies that Strether is the only psychological subject on exhibit in The Ambassadors, a comment she makes subsequent to her description of William's

\footnotetext{
${ }^{11}$ This relationship is evoked in the following quotation from Ryan's book: "At the origin of [William] James's famous phrase, 'stream of consciousness,' was a [...] practical recognition: that thought 'does not appear to itself chopped up in bits.' The moment-bymoment changes in consciousness are borne along by a sense of continuity that, however factitious, succeeds in overriding the fragmentariness of individual sensations" (14).
} 
“individualized self" suggests that another, less sensorial, and more properly linguistic or discursive, subject may be present in the text: "The ingenious maneuver by which he managed to retain the word 'self' while reducing it to a mere deictic or orienting word took William James some time to work out in detail, but from the very first he had made it clear that he wished to be able to pursue his skeptical questioning about the self without abandoning our familiar sense of it" (75, emphasis added). While Ryan equates William James's "individualized self" with the sensorial focalizer of Henry James's texts, this passage evokes a related, but nonetheless different, notion of subjectivity - one that she does not expound upon. This thesis will argue that this other notion of selfhood is on display in The Ambassadors, and that it is marked not by a point of perceptual reference, but by a centre of linguistic reference - the centre of a system of deixis. It will also argue that the difference between the focalizing protagonist and this other, linguistic subject is analogous to Genette's narratological distinction between the one who "sees" and the one who "speaks." Accordingly, James frames the protagonist of The Ambassadors so that it is akin to William James's individualized self, after which he - as the narrator - describes the movements of this framed subject, with the unilinear deixis of this discursive act structuring his own subjectivity. Thus, the relationship between William's pragmatism and Henry's fiction is evinced by the relationship between Henry's focalizing and narrato-authorial subjects.

One possible objection to the approach taken in this thesis is that the vocal component of James's The Ambassadors is better understood less by way of subtle distinctions between narrator and focalizer, between literary autonomy and heteronomy, and instead by the much more apparent idiosyncratic style in which James's late-phase 
works are written. The soft form of this argument is that the author's voice is recognizable in the stylistic voice that intermittently breaks through the otherwise neatly composed and predominantly authorless narrative (Aczel 471). The strong form depicts the late-Jamesian text as completely inundated in, and thus determined by, the very medium of the author's late style:

Both James's moralism and his perspectivalism [...] imply a poetics of division and differentiation. The Jamesian doctrine of "establishing one's successive centres" of consciousness [...] seems perfectly suited to this project. But $[\ldots]$ the style of James's writing actually interrupts the operation of this paramount Jamesian formal principle, inundating the drama of moral and perspectival difference in a bath of stylistic indistinction. (Kurnick 216)

And while these two types of argument have differing implications, both accord with the image of James's mature form of composition: dictation to an amanuensis. According to this image, the author's distinctive style is unmistakably present on the pages of the literary text because this text is a literal recording of the author's distinctive manner of vocalized speech. ${ }^{12}$ This idea is corroborated in an essay on James's compositional habits written by one of his amanuenses, Theodora Bosanquet: "The practice of dictation was begun in the nineties. By 1907 it was a confirmed habit, its effects being easily recognisable in his style, which became more and more like free, involved, unanswered talk" (7). This passage represents the author's voice as the generating instance of the narrative; it also figures the mechanical recording instrument as in no way implicated in the compositional process, save for the coincidental fact that it is the only thing able to

\footnotetext{
${ }^{12}$ See also Ringuette 126.
} 
keep pace with the author's free-flowing vocal discourse. But the picture of Jamesian dictation as "free" and "unanswered talk" is belied by a subsequent comment in Bosanquet's essay:

Indeed, at the time when I began to work for him, he had reached a stage at which the click of a Remington machine acted as a positive spur. He found it more difficult to compose to the music of any other make. During a fortnight when the Remington was out of order he dictated to an Oliver typewriter with evident discomfort, as he found it almost impossibly disconcerting to speak to something that made no responsive sound at all. (7)

Rather than the former image of the free-speaking author, this latter image that has James in conversation with a machine is the one that the current thesis will use to represent Jamesian voice. This thesis will thus develop the idea that Jamesian voice is not an initiating, instigating or inundating property, but rather something that exists as a result of, in conversation with, or in response to, the mechanical - specifically the mechanics of narrative construction. Voice will thus be figured as bearing a relationship to the narrative - as existing, by and large, as a product of the narrative - and not as the generating instance of, or as existing in an ontological realm distinct from, this narrative.

It is the picture of James conversing with a machine that, to borrow Rimmon's words, is "capable of representing different objects at the same time" (ix). This picture represents the dance-like back-and-forth between determining and being determined, between dictating and being dictated to, between exploiting mechanical innovation and existing as a function of such innovation, and between the Victorian standard of fullvoiced, omniscient narration and the Modernist one of silent, yet omnipotent and 
mechanical, narrative control. It also corresponds with the disorienting idea of James's complex national and literary-historical character. ${ }^{13}$ In the chapters that follow, the cacophony of influence that this image suggests will be rationalized in order to figure it in terms of cause and effect, that is, in order to elicit the ways in which James's literary innovations produced a vocalizing subject. One of the primary objectives of this thesis will be to elucidate the narrato-authorial subject using narratological terms, a process that will figure this subject as a product of James's narrative innovation and not, on the other hand, as primarily stylistic and thus unrelated or antithetical to the narrative.

Significantly, it will picture one of the most indicative features of the Victorian novel (the enunciating narrator) as a function of what might be termed Modernist narrative innovation. In effect, it will describe voice according to the dynamic that Ivan Kreilkamp delineates in the following: "Fiction combats speech that resists the authority of print culture, in order to come to the rescue of speech that produces and marks the highly individuated novel reader. The most valued forms of speech are those that at once subordinate themselves to print and, simultaneously, offer the promise of redeeming or humanizing that print" $(6) .{ }^{14}$ If James found it difficult to dictate without the aid of his mechanical interlocutor, it is because - like his innovations in the mechanics of narrative - this device made him speak. And if past critics have not been able to isolate this version of Jamesian voice, it is arguably because they have been subject to the inertia of

\footnotetext{
${ }^{13}$ Priscilla Walton writes, "James shares in the liminality of the colonial, if not postcolonial, subject, and thus does not fit neatly into any national category (being both American and English (perhaps even French) all at the same time" (35).

${ }^{14}$ Interestingly, Kreilkamp does not refer to James at all in his book-length study of voice and the Victorian novelist.
} 
dwelling upon the autonomous aspects of Jamesian narrative without proceeding to analyze the vocal implications of these autonomous textual features.

As has been stated, the thesis will be divided into two parts. The first part (Chapters 1 and 2) will develop a schema in which the text's two structuring elements the "focal" and the "vocal" - may exist in equal prominence; the second part (Chapters 3 and 4) will read The Ambassadors within the parameters of this schema in order to illustrate how these two components structure the text (focusing the balance of attention on the vocal component). Chapter 1 will mark the beginning of an investigation into suggestions made by Meir Sternberg that The Ambassadors contains a spatio-temporal structuring element (or thread) that is related to, but that is nonetheless distinct from, the much-studied narrative technique of limited third-person point of view. In an attempt to describe this element, the chapter will summarize the history of theories of Jamesian point of view to determine how this obverse structuring element came to be ignored, and how to best represent this element narratologically. The chapter will conclude by determining that Gérard Genette's Narrative Discourse provides a means of signifying this element, but that recourse to another paradigm - one that contextualizes the narrative text as an instrument that was developed and employed in a particular production context by the text's author - would expedite the process of identifying the thread. Chapter 2 will begin by proposing Pierre Bourdieu's theory of cultural fields as a means of contextualizing such a functional narrative text. It will proceed to analyze the trajectory of James's career in the years leading up to the publication of The Ambassadors in order to situate James in a rough instantiation of the British literary field. In the course of doing so, it will analyze James's income figures and personal correspondence during this 
period. One of the conclusions that will be reached in this chapter is that James did not act in strict accordance with the autonomous principle when he produced the text, but that he rather strove for both autonomous and heteronomous consecration when writing it. While the inscription at the textual level of the autonomous principle will be associated with James's use of the technique of third-person limited perspective (or as Genette would say, "fixed internal focalization"), the inscription of the heteronomous principle will be tied to Genette's concept of narrative voice. In particular, it will be determined in this chapter that the heteronomous inscription is meant to signify the narrato-authorial subject's possession of the bourgeois virtue of sustained voluntary attention. The second chapter will end with a summary of the means by which late-nineteenth-century experimental psychologists monopolized the virtue of sustained voluntary attention, at which point it will be argued that the narrative mode employed in The Ambassadors reflects James's attempt to appropriate this same virtue for himself. In summary, the first two chapters will develop a method for signifying the author's modal expression of both literary autonomy and heteronomy, and will conclude that the latter is inscribed through the length of the text with a vocal thread that is indicative of sustained voluntary attention.

Chapters 3 and 4 will read the text in the socio-narratological context developed in the first two chapters. Chapter 3 will take as its object the "organic whole" that is The Ambassadors. It will analyze all three components of narrative - story, narrative, and narrating - by using the relational paradigm that Genette develops in Narrative Discourse. Combining the sociological and narratological approaches, this chapter will figure the relationship between narrative and narrating as homologous to the relationship 
between the autonomous and heteronomous components of the text. It will proceed to describe this relationship as one by which the narrato-authorial subject's distinctive heteronomous features get constructed, with this subject acquiring the virtue of sustained voluntary attention by way of his relationship to the focalizing subject. It will conclude by demonstrating that this relationship is one that allows the narrator to maintain a unilinear narrative discourse. Accordingly, analepses are not narrated directly, in a sort of backsliding manner, but rather in a unilinear way, through the medium of a focalizing character who follows a linear geo-temporal course through the text. It will be argued that this is the way in which the narrato-authorial subject preserves the unilinearity of his narrative discourse, and thus promotes his own virtue of sustained voluntary attention. Chapter 4 will turn to an analysis of the more-strictly linguistic aspects of this vocal thread. The unilinearity of this thread will be illustrated through an examination of James's use of the pluperfect verb tense. It will be shown that the pluperfect is used in a consistent way that allows the narrator to narrate the analeptic content that gets elided during chapter breaks without seeming to "move back" into the anachronic space-time represented by the antecedent chapter break. The chapter will conclude by analyzing examples of another form of anachrony: instances of narrative prolepsis. The conclusion that will be drawn from this analysis is that the text's most significant proleptic passage does not signify the narrator's deviation from his unilinear progress along the narrative arc, but rather his attempt to redress a previous, unavoidable deviation from such unilinear progress. In this way, the final chapter will consist of a direct study of the object that the thesis set out to identify in the first place: what James refers to as the thread running through The Ambassadors. 
There is a possible objection that must be anticipated and addressed before this analysis of narrative voice in The Ambassadors may be undertaken. This has to do with the terminology that will be used in this thesis to identify the object of study. It will be observed that a number of different terms are used throughout the thesis to refer to what appears to be a single conceptual object; these include the terms narrator, narratoauthorial subject, narrative voice, and narrating instance. There is a rationale behind this multi-termed approach. The term narrating instance will be used to refer to the discursive subject who is constructed by way of his relationship to the narrative. ${ }^{15}$ Narrative voice will be used to identify the vocal aspect of the narrative in contradistinction to Genette's concept of narrative mood (thereby differentiating the one who sees and the one who speaks). The term narrato-authorial subject will be used to refer to a subject that is the textually-inscribed vocal representative of an author situated within the late-nineteenthcentury British literary field. And the term narrator will be used either to describe a general notion of the enunciating subject (as in the examples "Victorian narrator" and "omniscient narrator") or to refer to a combination of any number of the previously mentioned vocal subjectivities. In short, this multi-terminological approach is meant to represent the continuity between the textually-inscribed, linguistically- and narratologically-determined narratorial subject and the historical author existing in a particular intellectual and production context. It is also meant to signify that the intention of the thesis is not to refine any one narratological concept through reference to the

\footnotetext{
${ }^{15}$ This term figures the narrato-authorial subject as one component of Genette's tripartite conception of the text, the three components being story, narrative, and narrating. Genette describes his tripartite system in the following: "Analysis of narrative discourse will thus be for me, essentially, a study of the relationships between narrative and story, between narrative and narrating" (Narrative 29).
} 
Jamesian text, but rather to identify this text as an historical object that was composed according to the various contextual influences that impinged on its author. As a component of such a text, voice exists on a continuum between contextual imperative and textual inscription. It thus bridges the gap (in the case of The Ambassadors at least) between the narrative and extra-narrative (or diegetic and extra-diegetic) levels. In short, the use of a fluid definition of narrative voice throughout the thesis will not reflect terminological imprecision, but rather the fluid continuity between the narratological and sociological schema. 
Chapter 1: Grasping the Thread: Toward an Elucidation of the Spatio-Temporal Structure of The Ambassadors

In a letter of 1903 to the Duchess of Sutherland, Henry James gives the following advice on reading The Ambassadors: "Take, meanwhile pray, the Ambassadors very easily, very gently; read five pages a day - be even as deliberate as that - but don't break the thread. The thread is really stretched quite scientifically tight" (James, The Letters 302 , emphasis in the original). In this passage, James figures the novel as possessing a unifying structure that has as its basis (or spine) a quality that extends from the text's beginning to end. The passage also identifies the novel as a unified whole, echoing James's famous assertion from "The Art of Fiction" (1884) that a "novel is a living thing, all one and continuous, like any other organism" (862). But the difference between his image of 1884 and that of 1903 is the unilinear spatio-temporal suggestions of the latter. That is, rather than represent the text as an object that exists at a particular point in time, or as one that exists on no temporal basis at all, the thread identifies it as one that maintains its unity over a spatio-temporal duration analogous to the space-time of the codex being read. ${ }^{1}$ Like the organic text, the "figure in the carpet" is an oft-referenced metaphor in James criticism, and has been used to refer to the donnée or structural element that undergirds James's fictional works. ${ }^{2}$ The thread image identifies it, too,

\footnotetext{
${ }^{1}$ Gérard Genette describes the temporal relationship between the text and the act of reading in the following: "The narrative text, like any other text, has no other temporality than what it borrows, metonymically, from its own reading" (Narrative 34).

2 "The Figure in the Carpet" is a short story by James that was first published in 1896. It is about an author who insinuates to the story's narrator (a literary reviewer) that his body of works has a common theme or formal element running through its entirety. The story proceeds as a hunt by the narrator and two of his peers through the author's oeuvre for this - is it thematic? is it formal? - "figure in the carpet." Notably, the fictional author refers to this figure as "the very string $[\ldots]$ that my pearls are strung on" (33).
} 
(that is, in the case of The Ambassadors, at least) not as a static image, but as an object of spatial density that exists according to a time scheme homologous to that of reading. In the Sutherland letter, then, James suggests that with the right analytical approach the scientific basis of this spatio-temporal narrative structure may be understood and the nature of the organic whole or "figure in the carpet" may be described. The current chapter will take the first step toward developing such an approach. By tracing the history of the Jamesian concept of point of view it will both locate the current thesis in reference to past scholarship and mark the starting point from which the identification of The Ambassadors' spatio-temporal textual thread will be pursued - or the end from which this textual thread may be grasped.

Though the Sutherland letter makes explicit the idea that The Ambassadors possesses a coherent structure, implicit in the novel itself are indications of structural integrity; so many, in fact, that the novel has been considered the thematic and structural exemplar or paradigm of the Jamesian oeuvre. ${ }^{3}$ Because the novel was written in what is regarded as the author's prime, and because it rehashes many of the author's signature themes and motifs, it is often regarded as the fulfillment of the potential prefigured in James's earlier works. For example, James employs in the novel his predominant international theme, which pits American and European protagonists against one another in a complex and ambiguous social arena. He also reprises in Book XI, Chapter IV the

\footnotetext{
${ }^{3}$ F. O. Matthiessen writes, “'The Ambassadors,' the first of James' three crowning works to be completed, has proven by far the most popular work with the critics. In this they have followed his lead, since he announced in the preface that it was 'frankly, quite the best, "all round," of all his productions" (18).
} 
midnight vigil - first made famous in Chapter 42 of Portrait of a Lady ${ }^{4}$ - using it to give Strether occasion to reflect on the complex social implications of his coincidental meeting in the country with Chad and Madame de Vionnet (422-5). And James concludes the novel with his oft-used renunciatory ending, having the protagonist proclaim on the last page, "That, you see, is my only logic. Not, out of the whole affair, to have got anything for myself" (470). Indeed, all of James's major phase novels - The Wings of the Dove (1902), The Ambassadors (1903), and The Golden Bowl (1904) - can be said to employ these characteristic motifs and themes in one way or another. But the thing that distinguishes The Ambassadors from these others is the general recognition that it most strictly obeys the author's vaunted law of economy: "There is no economy of treatment without an adopted, a related point of view, and though I understand, under certain degrees of pressure, a represented community of vision between several parties to the action when it makes for concentration, I understand no breaking-up of the register, no sacrifice of the recording consistency, that doesn't rather scatter and weaken" (James, The Art 300). Unlike The Wings of the Dove and The Golden Bowl-which are told from the points of view of both the American and European contingents - The Ambassadors exemplifies the type of economy referred to here because it is told from the fixed (or limited) point of view of a single character: that of the American protagonist Lambert Strether. Being thus not scattered, not weakened, the novel presents itself as the strongest, most focused of James's works: it is the loadstone of the Jamesian monument

\footnotetext{
${ }^{4}$ Coincidentally, M. H. Abrams' A Glossary of Literary Terms cites Chapter 42 of Portrait of a Lady as exemplary of the stream of consciousness mode in fiction (308); importantly, the author of this entry is careful to refer to the stream of consciousness mode as it is on display in Portrait as "the narrator's description of the sustained process of Isabel's memories, thoughts, and varying feelings" (308, emphasis added).
} 
or the focal point of the Jamesian vision. It is the text in which James's characteristic formal and thematic traits can be said to come together in one typological instance, which is due to the inclusion of the author's most oft-used themes and motifs and, more importantly, the consistency with which the technique of limited point of view is applied throughout.

If the novel exhibits a sustained application of James's signature technique, and if the thread image refers to a characteristic that is stretched throughout the novel's entirety, then there is doubtless a correlation between the technique of limited point of view and the textual thread. Indeed, this hypothesis is not original, but has been proposed already by Meir Sternberg. Sternberg writes, "if the advertised face of the Jamesian novel is the limitation of perspective, then its hidden face lurks above all in what I would call spatiotemporal composition, where some lessons probably derived from the spatial arts are brilliantly projected into the temporalities of narrative" (776). Here, Sternberg paints an evocative picture of the Jamesian text using an image that connotes both duality and spatio-temporality: the two-faced figure of the Janus. ${ }^{5}$ Accordingly, the structure underlying the Jamesian text is like the Janus in that it provides a linear temporal sequence, serving as it does to bridge past and future. The Janus also evokes the two faces of the Jamesian text: the visage that the novel shows to the world is that of limited perspective, while the one that it hides is the spatio-temporal structure that is

5 "Janus was the first [Roman] god of all doorways: of public gates (jani) through which roads passed, and of private doors. His insignia were thus the key which opens and closes the door, and the stick (vinga) which porters employed to drive away those who had no right to cross the threshold. His two faces (Janus bifrons) allowed him to observe both the exterior and interior of the house, and the entrance and exit of public buildings. [...] Being god of the gates he was naturally god of departure and return and, by extension, the god of all means of communication. [...] Janus was also the god of 'beginnings.' As a solar god he presides over daybreak" (Guirand 200). 
distinguishable from, but nonetheless related to, its public face. And just as the Janus represents a doorway into the as-yet-unknown, Sternberg identifies the technique of limited perspective that is on prominent display in the Jamesian text not as the highwater-mark of Jamesian poetics, but rather as a phenomenon that promises to be a gateway to an understanding of the text's deeper spatio-temporal narrative structures. But it is important to note that while Sternberg makes this assertion, he does not regard the two things - the technique and the structure - as synonymous. To paraphrase James, an analysis of the thread running through The Ambassadors that figures it in terms of the technique of limited point of view alone forfeits half, or much more than half, of this image's signifying power (Edel, Letters 683 ). In other words, lurking behind the oftanalyzed narrative technique is an obverse side or face: the image of the hitherto uncharted spatio-temporal thread.

Sternberg continues on to write, "This set of organizing principles - perspectival, spatial, temporal - interact throughout the [Jamesian] canon. Their orchestration actually reaches its most impressive form in works of the late period" (776). For Sternberg, the "most impressive" spatio-temporal structures are on display in works such as The Ambassadors, in which they bear a relation to the technique of limited perspective. But while he states this at the beginning of his essay, he does not proceed to analyze one of these later works, but instead focuses his study on The Tragic Muse, which was first 
published in 1890 - well before the onset of the late phase. ${ }^{6}$ Indeed, Sternberg uses The Tragic Muse to highlight the spatio-temporal structure of the Jamesian text precisely because it is one of the few texts that does not use the technique of limited perspective, and thus displays its spatio-temporal framework in sharper relief: "In terms of official doctrine, The Tragic Muse is indeed remarkable for the incongruity of its composition, but by reference to actual practice, that composition only radicalizes and foregrounds a structural constant" (777). For Sternberg, while the spatio-temporal structure of the lateJamesian text is more technically impressive, that of The Tragic Muse is more apparent, given that an analysis of the latter text is not as amenable to confusion between its perspectival and spatio-temporal elements. Perhaps another reason why Sternberg chose to focus his study on this earlier text as opposed to The Ambassadors was in order to distinguish his own contributions from those of past critics. If Jamesian point of view is a concept that was thought to have been over-analyzed throughout the early- to midtwentieth century, writing in 1984 , Sternberg must have felt the pressure to write about an element in the Jamesian text entirely unrelated to the one that had been so much studied in the then-too-recent past. But in doing so, Sternberg surrendered the opportunity to elucidate what he terms the more impressive spatio-temporal structures of the later works. The current thesis constitutes a belated extension of Sternberg's own critical program, as it will attempt to identify the spatio-temporal structure of one of James's

\footnotetext{
${ }^{6}$ Matthiessen writes that James's "late" or "major" phase begins around 1900, the point at which James "felt his way into [...] composition" of The Ambassadors (18). In the introduction to the Penguin Classics edition of The Ambassadors, Adrian Poole suggests that the onset of this phase was signaled by the author's shaving of his immemorial beard: "In May 1900, a few weeks after he turned fifty-seven, Henry James shaved off his beard $[\ldots]$. He was steeled for a new century, $[\ldots]$ and he was about to embark on the three great novels in which his career would climax" (xv).
} 
late-phase works as it relates to - and is yet distinct from - the technique of limited perspective that has been so extensively analyzed in the early-to-mid-twentieth century. It will do so by figuring the thread image as the obverse of the technique of limited perspective, or the second face of the Janus. Toward this end, it will pay to first chart a brief history of the theoretical development of the concept of limited perspective in an attempt to delineate the face on the Janus that looks back to the scholarly past, so that the other face - the one that gives a glimpse into the future and stands in for the text's hidden spatio-temporal structures - may be elucidated.

The first theorist to treat The Ambassadors as a narrato-theoretical exemplar was Percy Lubbock. In The Craft of Fiction (1921), Lubbock focuses on this novel in order to illuminate the theory of narrative that is implicit in the Jamesian text. The author describes James's contribution to theories of narrative, summarizing it in the following way: "Henry James was the first writer of fiction, I judge, to use all the possibilities of the method with intention and thoroughness, and the full extent of the opportunity which is thus revealed is very great. The range of method is permanently enlarged; it is proved, once and for all, that the craft of fiction has larger resources than might have been suspected before" (172). Lubbock attributes to James a superabundant battery of narrative techniques, suggesting that the exposition of a thoroughgoing narrative theory would best be accomplished by tackling this arsenal: "there he stands, foursquare to all our theories of the novelist's art; and they may blow where they list, but it is still with the burly figure of Henry James that they have first to reckon" (xi). When it comes to describing this contribution qualitatively, Lubbock identifies it as James's characteristic technique of narrative perspective - specifically that of restricted third-person point of 
view. While Lubbock recognizes in James's textual economy a variety of narrative phenomena, he identifies the type of perspective on exhibit in The Ambassadors as the coup d'etat in the evolution of narrative fiction, as it allows the reader to watch the protagonist's consciousness as if it were perched on a stage: "The Ambassadors, then, is a story which is seen from one man's point of view, and yet a story in which that point of view is itself a matter for the reader to confront and watch constructively" (170). According to Lubbock, James achieves this dramatization of consciousness in two ways: by restricting the narrated events to things that only Strether could reasonably perceive, and by narrating these events using third-person pronouns (162). It is obvious how limiting the narrated events to things perceivable by a single character achieves this effect; subtler is the way in which third-person narration contributes to the dramatization of consciousness. In contrast to first-person narration, which usually signals a retrospective relationship between the narrator and the events narrated, third person narration - as it denotes no such retrospection - allows for the real-time unfolding of conscious thought (Lubbock 162). In short, this method allows the author to represent the suspense, limited cognizance, and temporal continuity of verisimilar consciousness. Thus for Lubbock, the restricted third-person point of view is not an end in itself but the principal narrative technique by which "the picture of the mind is fully dramatized"allowing "the author to withdraw, to stand aside, and to let Strether's thought tell its own story" (156). Through its strong association with this coup, restricted third-person point of view is figured by Lubbock to be the narrative technique par excellence.

But while Lubbock argues that this technique plays a particularly important part in James's textual economy, he does not view it as constituting the author's entire 
contribution to the theory of narrative. Referring to James, Lubbock writes, "thus it happens that the novelist who carried his research into the theory of the art further than any other - the only real scholar in the arts - is the novelist whose methods are most likely to be overlooked or mistaken [...]. They still wait to be fully assimilated into the criticism of fiction; there is much more in them, no doubt, than the few points I touch on here" (187, emphasis in the original). It is a curious fact, then, that one of the narrative theorists who most famously took up Lubbock's theories treats the conclusions drawn in The Craft of Fiction as the final word on Jamesian narrative. Writing in 1955, Norman Friedman adopts Lubbock's notion that narrative perspective is the chief concept by which narrative may be understood, and uses this insight as the basis of his own theory. In his essay, Friedman distinguishes between different narrative types, identifying each by the degree of authorial presence it implies: "point of view provides a modus operandi for distinguishing the possible degrees of authorial extinction in the narrative art" (1163). Like Lubbock, Friedman views the restricted third-person point of view as the means by which the author withdraws from the text, thereby "showing" - that is, instead of "telling" - the narrative. Echoing Lubbock, Friedman writes, "one of the chief means to this end, the one James himself not only announced in theory but followed in practice, is to have the story told as if by a character in the story, but told in the third person. In this way the reader perceives the action as it filters through the consciousness of one of the characters involved" (1164). But while James is the most contemporaneous novelist analyzed by Lubbock in The Craft of Fiction, he is, in Friedman's work and according to Friedman's perspective, a somewhat antiquated literary progenitor. Accordingly, Friedman uses Lubbock's cursory theory of Jamesian narrative perspective to study the 
novels of Hemingway, Woolf, Joyce, and Forster - Modernist novelists who were writing after James's acme. In this way, Friedman represents Modernist novels as taking up and hypostasizing the techniques that were avant-garde in James's day.

Recognizing that Friedman's theory is largely an extension of the one put forth by Lubbock in The Craft of Fiction, it must be noted that the two theorists' respective valuations of Jamesian narrative innovation differ starkly. Friedman agrees with Lubbock's idea that the more the point of view of a narrative is limited to that of its protagonist, the less the author contributes to the narrative's body of commentary, judgment, and perception, and thus the less the author figures in the narrative as a whole. But instead of viewing the evacuation of the author from the text as an heroic accomplishment, Friedman judges restricted third-person point of view as signaling a turn in the history of narrative fiction towards moral regression: "Perhaps, however, with the final extinction of the author, fiction as an art will become extinct as well, for this art, while requiring some degree at least of objective vividness, requires as well, it seems to me, a structure, the product of a guiding intelligence which is implicit in the narrative and which shapes the material so as to arouse the reader's expectations" (1179). Writing thirty years after Lubbock - and after much more literary experimentation - Friedman expresses exasperation with Modernist narrative techniques, figuring them as contributing overmuch to the art of the novel but little to the morality of the same. But rather than anticipate post-modernity, he harkens back to a time of narratorial omniscience and authorial presence. In short, in his work, Friedman adopts Lubbock's theory of narrative perspective without questioning its theoretical implications: for example, he does not distinguish between the theory of narrative on display in James's 
fictional texts and the one outlined by Lubbock in his theoretical text. Instead, he only amends Lubbock's conclusions by questioning the moral implications of the narrative technique that Lubbock described with honorifics.

So while Lubbock recognized the limitations of his own theoretical appropriation of James, arguing that the author's novels contain much more nascent theoretical material than he himself was able to describe, Friedman took up Lubbock's text as the comprehensive basis of a narrative theory, only quibbling with Lubbock on moral grounds. The logical extension of this theoretical tradition, then, would be a revision of Lubbock's theory that appreciates James as the "burly figure" and thoroughgoing "scholar" of narrative theory not only in figurative or moral terms, but in narratological terms as well. This would be a theory that recognizes the Jamesian text as exemplary of more than merely a particular form of narrative perspective. One theorist who acknowledges the importance of perspective, but who also confers to it a diminished status in a larger overall theoretical economy, is Gérard Genette. This is demonstrated by the layout of Genette's influential book, Narrative Discourse: An Essay in Method (1980). Of the five chapters that make up the book, Genette restricts the explication of narrative perspective to the single chapter on what he refers to as narrative mood. In this chapter, Genette takes up the conclusions drawn by Lubbock and Friedman about Jamesian perspective, giving a short history of this tradition in the following: "We know how this contrast [that is, between mimetic and diegetic narration] abruptly surged forth again in novel theory in the United States and England at the end of the nineteenth century and the beginning of the twentieth, with Henry James and his disciples, in the barely transposed terms of showing vs. telling, which speedily became the Ormazd and 
Ahriman of novelistic aesthetics" (163, emphasis in the original). Here, Genette makes two implicit criticisms of the Anglo-Americans' appropriation of James. First, he criticizes the degree to which these theorists focused on narrative perspective to the exclusion of all other narrative phenomena. By describing the trend as one that "surged forth" and "speedily became," he identifies the importance bestowed on the concept as developing by way of an immoderate theoretical trend, one disproportionate to the actual role played by the technique in narrative texts. Second, Genette criticizes the moral connotation that has come to be attached to the function. By referring to "showing" and "telling" as the "Ormazd" and "Ahriman" - the antiquated "Zoroastrian good and evil principles" (Genette, Narrative 163) - he expresses regret at the roles these techniques have come to play in moral debates about narrative. To distinguish himself from this tradition, Genette emphasizes the objectivity of his own approach: "From our own strictly analytic point of view it must be added [...] that the very idea of showing, like that of imitation or narrative representation [...] is completely illusory" (164). Genette's revision thus involves an attenuation of the importance of narrative perspective within the narrative text, as well as an attenuation of the moral connotations of the function.

Thus, while Lubbock suggests that James had more to contribute to narrative theory than a refined notion of narrative perspective, Genette's theory constitutes an extension of the work that Lubbock had set out to execute in The Craft of Fiction, since he treats perspective as an integral, but nonetheless limited, component of his theory. Accordingly, Genette's theory promises to be able to identify the "other" Henry James: the spatio-temporal obverse of Jamesian point of view. For instance, in Narrative Discourse Genette gives a fuller, more scientific picture of the narrative text, echoing 
James's appeal to the Duchess of Sutherland to pay attention to the thread stretched "scientifically tight" throughout The Ambassadors. Jonathan Culler identifies the scientific inclination behind Genette's work, describing it as part of a project that "was to develop a poetics which would stand to literature as linguistics stands to language and which therefore would not seek to explain what individual works mean but would attempt to make explicit the system of figures and conventions that enable works to have the forms and meanings that they do" (8). Culler also describes the comprehensive quality of Narrative Discourse when he writes that Genette's is "the most thorough attempt we have to identify, name, and illustrate the basic constituents and techniques of narrative" (7). This comprehensive quality is also elicited in the terms Genette uses to name the different narrative categories; by employing grammatical terms, Genette suggests that his narratological methodology is analogous to the comprehensive grammatical one that parses, categorizes, and names every component of the sentence. Culler also argues that Genette's text blurs the boundaries between criticism and theory - that it is an example of both the theoretical and the critical: "Genette quite rightly refuses to choose between these two alternatives, but this does not mean that his work should be viewed as something of a compromise, neither one nor the other. On the contrary, it is an extreme and unusual example of each genre" (9). ${ }^{7}$ Thus, not only does Genette's method promise to be scientific enough and comprehensive enough to be able to represent the thread stretched scientifically through the entire text; with its narrato-critical element, it also has

\footnotetext{
${ }^{7}$ While Genette's book has been received as a theoretical text, and while the author postures, for the most part, throughout the text as a theorist, the opening sentence of the book's preface makes clear that it also has a critical objective: "The specific subject of this book is the narrative of A la recherche du temps perdu" (21).
} 
the potential to be exemplary of the proper approach to take in order to describe this entity from a narrato-critical standpoint.

However, if Genette's methodology - with its comprehensive and scientific nature - exists as a potential means of elucidating the thread running through The Ambassadors, his work as it stands is not exemplary of the proper way to analyze James's text. That is, while Genette takes up the Jamesians, criticizing them for overemphasizing only a particular feature of narrative, the way in which he represents the Jamesian text in his own work demonstrates a similar ignorance. Of all the categories dealt with in Narrative Discourse - narrative order, duration, frequency, mood, and voice - Genette confines his references to James solely within his chapter on narrative mood. ${ }^{8}$ Thus, whereas Lubbock represents a Jamesian text with profound and numerous potential contributions to narrative theory, Genette paints a picture of a text thinned to the point of being merely exemplary of a single esoteric narratological phenomenon. For example, he divests the technique on exhibit in The Ambassadors of the evocative term "point of view" and renames it with the relatively sterile one of "focalization." But this does not represent the extent of Genette's particularization of James's contribution, as the Jamesian text gets further particularized by being merely exemplary, in Genette's paradigm, of the sub-category of "fixed internal focalization" - a technique by which "the narrator says only what a given character knows" (Genette, Narrative189). By renaming this aspect of the Jamesian text, Genette can be said to invert the synecdoche: whereas for

\footnotetext{
${ }^{8}$ A glance at the "James" and "Jamesians" entries in the index of Narrative Discourse is enough to verify that this is the case.

${ }^{9}$ The apparent sterility of this term, stripped of its broader connotations of "perspective" and "point of view," has doubtless served as a factor in its being adopted as the flagship of narratology (that is, given that it is only seen to have meaning in the context of literary narrative).
} 
Lubbock this particular feature was to stand in for the text's eminence in a literary history, for Genette, the Jamesian text and its signature technique represent merely a minor component of an overall treatise on narrative theory. Narrative Discourse is thus a textual constellation in which the Jamesian text exists as but a speck, and a place where the living Jamesian organism has come to die and be hypostasized in this technocratic way.

Of course the representation of the Jamesian text on display in Genette's narratological treatise is not an accurate depiction of this text. James's confined place within the textual economy of Genette's work does not represent the thinness or technicality of the Jamesian text, but rather Lubbock's inadvertent thinning of it with his focus - perforce due to the brevity of his study - on a single aspect of narrative. This limited focus became consecrated when Friedman gave it a comprehensive aspect due to the vital importance it had in structuring his own theory of narrative. Thus, Genette is merely taking Lubbock and Friedman at their words when he limits James's narratological contributions to a single concept. Dorothy Hale echoes this idea when she writes, "Genette [...] has no desire to save James from his followers; he even goes so far as to cite a quotation from Lubbock to characterize the Jamesian tradition as a whole" (78). But given that Genette recognizes the pivotal role played by the Anglo-American Jamesians in creating a skewed version of the Jamesian text, why does he include their version of this text in Narrative Discourse and not James's own? In other words, why does Genette refuse to take advantage of the "burly figure" of Jamesian narrative when developing his own theory? The most obvious reason for this is that Genette had already chosen Proust's À la recherche du temps perdu to fill the role of primary textual 
exemplar. But another reason has to do with James's ineluctable importance to the Anglo-American school of narrative theory. Recognizing this importance, Genette distanced and distinguished himself from this school by limiting references to James's texts when devising his own theory. Referring specifically to Genette's interpretation of James and Lubbock, Hale writes, "As James is more and more conflated with and known by his Lubbockian legacy, and as Lubbock's work is itself reduced to the slogan 'show don't tell,' it becomes easier to both ignore and reproduce the philosophical assumptions of [James's] Prefaces and The Craft of Fiction" (68). She also writes, "Genette identifies Anglo-American objectivists such as Percy Lubbock as the fountainhead of the theory he opposes" (77). Hale thus argues that Genette's misappropriation of James through Lubbock is a sort of political move which allows him to stress the eminence of his own theory by way of contradistinction to the founding fathers and propositions of the AngloAmerican school of narrative theory. And by misrepresenting the contributions of these theorists, Genette is able to appropriate, under his own signature, the theoretical content that he elides with this misrepresentation. Thus it can be said that the Jamesian text is present in Genette's Narrative Discourse; however, due to what may be termed the politics of academic inquiry, Genette does not disclose the full force of this presence.

A curious thing about the chapter in Narrative Discourse on mood - the place in Genette's text in which the Jamesian text has come to be consecrated narratologically - is that it is the only category within this work that is primarily structured on a spatial, and not a temporal, basis. The chapters on "order," "frequency," and "duration" are arranged by Genette under the heading of "tense," dealing as they do with "temporal relations between narrative and story" (Genette, Narrative 31). The concept of "voice" is also 
structured on a temporal basis, since it is a textual indicator that is appreciable for the reason that one can "tell a story without specifying the place where it happens" but "it is almost impossible [...] not to locate the story in time with respect to [the] narrating act" (Genette, Narrative 215). However, when describing the one remaining category, narrative mood, Genette writes that this concept is based on the idea that "the narrative can $[\ldots]$ keep at a greater or lesser distance from what it tells" (162, emphasis in the original). Genette goes on to expand on this idea: "'Distance' and 'perspective,' thus provisionally designated and defined, are the two chief modalities of that regulation of narrative information that is mood - as the view I have of a picture depends for precision on the distance separating me from it, and for breadth on my position with respect to whatever partial obstruction is more or less blocking it" (162, emphasis in the original). Mood is thus the only primarily spatial category in Genette's theoretical economy. What this means is that the spatial half of the spatio-temporal text - or one of the two faces of the Jamesian Janus - is on display in Genette's chapter on narrative mood, while the other, temporal half (the "other" Henry James) is to be located using the concepts contained in the other chapters of Genette's text. Thus the next logical step will be to release the Jamesian text from its localized spot within Genette's Narrative Discourse into the greater expanse of Genette's textual space, thereby giving it a broader - and thus more temporal - relevance in relation to Genette's theory. This process can be described as discovering in Genette's narratological paradigm a Jamesian text that is more Genettean than the one Genette himself portrays in his work. It is a process of putting the critical analysis of James's work into Genette's Narrative Discourse, thereby relating 
James's novel to Genette's text in much the same way that Proust's $\grave{A}$ la recherche $d u$ temps perdu already exists in relation to Genette's methodology.

The obverse face of the Janus thus stares into a narratological expanse: the chapters of Narrative Discourse in which James is not yet explicitly present. Now it becomes a question of the route to be taken through this expanse in order to trace the thread running through The Ambassadors. But at this point it becomes apparent that the next step must not be taken too hastily, lest we arbitrarily choose one or a combination of the many temporo-narratological concepts (narrative order, frequency, duration, or voice) to represent the Jamesian thread. At this point there is also the danger of conflating, in a sort of anachronistic manner, James's fictional text and Genette's theoretical one. In Narrative Discourse, Genette uses Recherche to outline his own theory of narrative. In the context of the current thesis, though, the relationship must be inverted, as it is the signifying power of Genette's theory that must be harnessed to elucidate the Jamesian text and not vice versa. But the question that arises is: If these narratological concepts serve to signify something, what are they supposed to signify? A thread, yes, but what is the function of the thread? And why does James emphasize this image in the Sutherland letter? Peter Rawlings suggests a means of addressing these questions. Rawlings argues that the Anglo-American theorists of narrative who have used James to develop their theories of narrative point of view have misrepresented James as an author whose objective it was to develop a consistent narrative theory of his own. In contrast, Rawlings' approach to reading Jamesian narrative is based on the assumption that James "neither offered, nor wanted to offer, any kind of consistent theory of narrative, and that he did not inaugurate the concepts of the 'point of view' and 'centres of consciousness"' 
("Narratives" 38). For example, rather than describe phenomena such as Jamesian point of view in purely narratological terms, Rawlings states, "it is essential to emphasize the ocular, visual and optical dimensions of the phrase point of view" ("Narratives" 47). In short, while narratological terms such as "point of view" have signifying power, Rawlings argues that they should not be applied in order to describe the Jamesian text as structured on the basis of a narratological paradigm; instead, they should be used to describe the text's relationship to, and participation in, turn-of-the-century scientific and philosophical discourses. Indeed, “the neglected paradigm for James's reflections on and adoptions of point of view is that of turn-of-the-nineteenth century science and philosophy, a paradigm much more significant than New Critical and formalist appropriations of James's criticism have been able or willing to acknowledge" (Rawlings, "Narratives" 44). For Rawlings, an analysis of James's work that describes it with the aid of narratological concepts alone does not identify the concepts that actually served to structure Jamesian narrative; these are rather philosophical and psychological concepts such as the ones his brother William James was attempting to elucidate in works such as The Principles of Psychology. In reference to the current thesis, Rawlings' observations suggest that in order to conduct an analysis of The Ambassadors using Genette's theoretical concepts - but neither in sole reference to his narratological paradigm, nor in a way that arbitrarily traces a spatio-temporal thread through the text - such a reading must be organized in reference to the historical context of James's work. ${ }^{10}$ According to

\footnotetext{
${ }^{10}$ Richard Aczel expresses a similar idea when he writes, "For the study of narrative discourse the pragmatic criteria of reading have to be systematized according to principles of usefulness" (493).
} 
Rawlings, this context is an intellectual one made up of the philosophical and psychological theories that were "in the air" at the time of the text's publication.

But just as the narratological analysis of the Jamesian text has to address the idea that James was not a practicing narratologist, so too does this contextual approach have to confront the fact that James was not a practicing psychologist or philosopher. Because James was neither of these things, his narrative structures cannot be read as means of simply or consistently conveying philosophical or psychological concepts. About James's use of psychological language, Seymour Chatman writes,

But though the vocabulary is rich, the actual amount of psychological distinction is small, and most of the variety is, like much else in James, elegant variation. The range of mental activity is fairly narrow, in comparison to that of an author like Dostoievsky. Further, James was no more a professional psychologist than a professional philosopher; his psychological terms are not introduced to analyse characters so much as to emphasise that their most characteristic activity is thinking. (10)

Judith Ryan expresses a similar idea. Ryan argues that turn-of-the-century psychology had an effect on James's fiction, and suggests that this influence began to express itself at the moment in 1890 when William James published The Principles of Psychology (76). However, she questions the equivalence of literary and psychological practices when she writes: "precisely because it is not a question of philosophy being channeled into literature, not simply a question of a thinker 'influencing' a writer, the literary responses to empiricism do not occur in lockstep with the development of empiricist psychology itself" (4-5). But while James was neither a professional psychologist nor a professional 
philosopher, he was most certainly a literary agent operating within a particular production culture. And whereas the philosophical and psychological discourses that permeated his intellectual milieu no doubt had an impact on his narratives (as will be demonstrated in the next chapter), he must be considered, first and foremost, as a literary agent and not as a collegial philosopher or psychologist. Thus, the best way to proceed with a narratological reading of The Ambassadors is to use a functional approach that figures James's narrative technique as fulfilling an objective - or a number of objectives - for the literary agent who is its author. As it will be demonstrated in the next chapter, one way to structure such an analysis is on the basis of James's position as a literary agent in the turn-of-the-century British literary field, and not in reference to his function as a proto-narratologist, psychologist, or philosopher.

In summary, Genette's Narrative Discourse offers a variety of concepts with which to extend the history of narratological analysis of the Jamesian text by identifying the spatio-temporal thread running through The Ambassadors. But rather than proceed with this project by sporadically tracing all of the possible spatio-temporal paths in an attempt to somehow alight upon the aforementioned thread, and rather than juxtapose Jamesian narrative with psychological discourse in the hope that the latter will somehow disambiguate this spatio-temporal narrative structure, it will pay to move in the opposite direction and first identify the objective that James aimed to achieve through the use of his narrative technique within a particular production context, afterwards tracing, with the help of Genette's narratological paradigm, the spatio-temporal thread that leads to this objective. Taking a cue from the title of James Kurnick's 2007 essay “What does Jamesian Style Want?" the next chapter will tackle the question, What does Jamesian 
narrative want? Of course, this question only has meaning within a structured context. In order to determine the function that Jamesian narrative is meant to perform, the next chapter will draw on Pierre Bourdieu's concept of the field of cultural production, as well as the extensive biographical information about James on display in works such as Leon Edel's The Life of Henry James and Michael Anesko's “Friction with the Market": Henry James and the Profession of Authorship, in an attempt to place late James within the British literary field of the late-nineteenth century. To use Bourdieu's terms, the next chapter will determine James's "position" within this field at the turn-of-the-century, as well as the act of "position-taking" indicated by his novel The Ambassadors. Only after such positioning work has been conducted will the thesis return to an analysis of James's narrative techniques and his participation in turn-of-the-century psychological discourses, considering these things in terms of their use value for an author situated in a particular production context. 
Chapter 2: The Dueling Dispositions of Late James and the Clinical Construction of Sustained Voluntary Attention

One is reminded of Proust's comment: "A work that is stamped with theories is like an object that is still stamped with its price." (Bourdieu, The Field 160)

It was determined in the previous chapter that in order to identify the spatiotemporal thread running through The Ambassadors it is imperative to address the following question: What does Jamesian narrative want? To answer this question, it will be of assistance to first delineate a contextual space in which this question has meaning. Based on the conclusions of the previous chapter, such a contextualizing schema would put the actions of literary producers in a meaningful context, and distinguish the motivations influencing such producers from those acting on, for example, professional psychologists and philosophers. One such schema is Pierre Bourdieu's field of cultural production. In the following, Donatella Izzo describes the particular quality of Bourdieu's concept of social fields that marks it as pertinent to such an approach: "Bourdieu's well-known argument runs as follows: each social world in a complex society tends to organize itself as a relatively autonomous universe or 'field', governed according to its own rules - hierarchies, stakes, techniques, traditions, institutions, values - which are specific to that field and irreducible to another field" (67-8). Here, Izzo stresses the highly structured and autonomous qualities of social fields. Izzo goes on to state that although each field is discrete, the literary field is particularly distinguished by the fact that autonomy is its "founding and defining value" (68, emphasis in the original). 
The literary field is thus doubly distinct, meaning that an elucidation of James's fiction in sole reference to the psycho-academic field would misrepresent the generative context of this work. Conversely, an analysis of the spatio-temporal thread that construes this object in reference to James's position and trajectory within the British literary field has the potential to elucidate the impetus behind it. In what follows, Henry James will be positioned in a rudimentary reconstruction of the British literary field in order that the contextual forces determining the spatio-temporal structure of The Ambassadors intellectual, monetary, and literary-political - may be better understood.

Bourdieu's literary field is a radically relational space of positions that is occupied by literary producers. Any picture of the field is a snapshot of a cultural economy in a particular place and at a particular moment in time. Bourdieu gives his most concise summary of this structure in the following:

The science of the literary field is a sort of analysis situ which establishes that each position - e.g. the one which corresponds to a genre such as the novel or, within this, to a sub-category such as the "social novel" [roman mondain] or the "popular" novel - is subjectively defined by the system of distinctive properties by which it can be situated relative to other positions; that every position, even the dominant one, depends for its very existence, and for the determinations it imposes on its occupants, on the other positions constituting the field; and that the structure of the field, i.e. of the spaces of positions, is nothing other than the structure of the distribution of capital of specific properties which governs success in the field and the winning of the external or specific profits (such as literary prestige) which are at stake in the field. $(30$, square brackets in the original) 
Bourdieu portrays in his work a particular permutation of this model: the literary field in France in the second half of the nineteenth century (Figure 1). The positions within his field are represented by various literary genres, such as Symbolist poetry, psychological and naturalist novels, and boulevard theatre. Spatio-conceptually, this space is structured on the basis of two axes. The $\mathrm{x}$-axis is positioned in reference to the economic field, with genres that command high profits lying at one end, and those that receive little or no economic profits lying at the other. The y-axis is positioned in relation to the field of power, with well-established genres lying at the positive pole, and genres with little or no consecration - relatively young or "green" genres - lying at the negative one. In this respect, the literary field's positive pole of legitimacy is aligned with the positive pole of the political field, in which the literary field exists as a subfield. Importantly, though, Bourdieu calls his field "the economic world reversed" because the positive pole of the literary field aligns with the negative pole of the economic field (that is, the position at which literary producers operate with the most autonomy from the influence of the market): "The position of 'pure' writer or artist, like that of intellectual, is an institution of freedom, constructed against the 'bourgeoisie' [...] and against institutions" (Bourdieu 63). Bourdieu refers to the artist associated with this position as the "autonomous" artist, whereas the one associated with the positive economic pole - and thus the negative literary pole - he calls the "heteronomous" artist. And while this description represents the structure as dichotomous, the space is rather a continuum in which each position is identified through a nuanced relationship to the various other positions in the field. Thus, there exist degrees of legitimacy and degrees of autonomy, with these qualities existing 


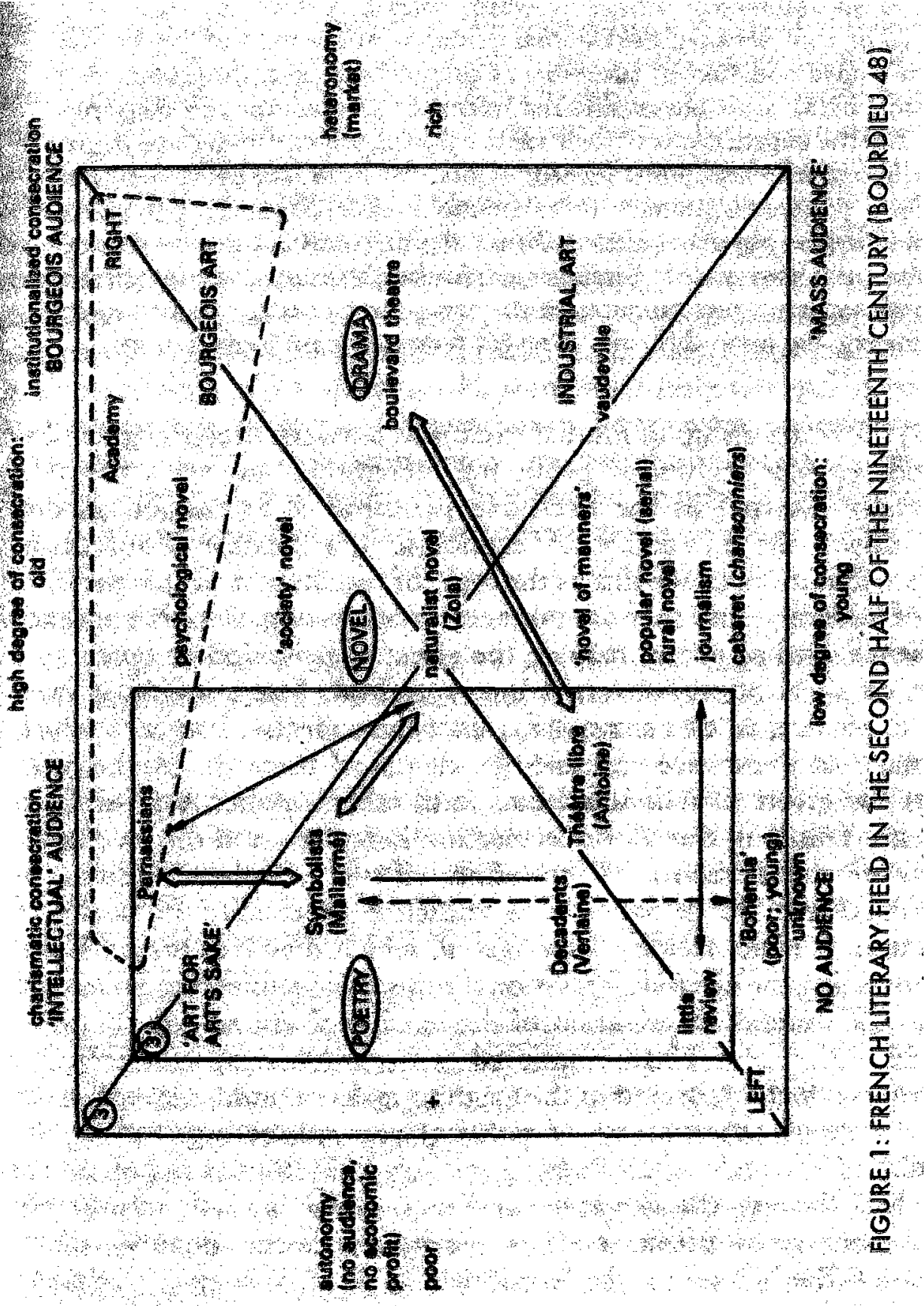


not in absolute terms but in relation to the variety of positions within this complex economy.

According to Bourdieu's theory, the behaviour of any one participant within the literary field is determined by the field's structure, and also by the dispositions that this participant possesses, and then emphasizes, in order to navigate the field: "To understand the practices of writers and artists, and not least their products, entails that they are the result of a meeting of two histories: the history of the positions they occupy [within the field] and the history of their dispositions" (61, emphasis added). By strategically employing their dispositions, literary artists mediate their relationships to the other positions within the field, and thereby attempt to maximize their literary or symbolic capital. Bourdieu refers to such strategies as "position-takings." It is my contention that if James could be positioned within the British literary field of late-nineteenth- and earlytwentieth century, and if the instance of "position-taking" indicated by The Ambassadors could be isolated - that is, by determining how James uses his dispositions to achieve an ascendant position in one of the field's hierarchies - then it is feasible that the work performed by the spatio-temporal thread could also be determined. The questions that will be addressed in the course of this investigation are the following ones: When James is writing the novel, is he positioned closer to the heteronomous pole of the economic axis, or is he nearer the autonomous one? And what implications does this have for the narrative strategies employed by James, and thus for our own narratological analysis of his work? By addressing these questions in the current chapter, the nature of the spatiotemporal thread may be determined in the subsequent chapters. 
A vast amount of information is required to reconstitute any instantiation of the literary field, including that of the British literary field at the end of the nineteenth century. ${ }^{11}$ For this reason, the work of researchers who have previously conducted such reconstitutions will be drawn upon in order to preserve the concision of the Bourdieuian component of this thesis. One such researcher is Mary Poovey who, in her essay on the subject, argues that "[d]uring the second half of the nineteenth-century, the lineaments of what Pierre Bourdieu has called the modern literary field were established in Britain, as they were in France" (433). In describing this cultural transformation, Poovey explains some of the factors involved, one of which was the increasing participation of novelists in the practice of literary reviewing. The evolution of this practice both signaled and contributed to the delineation of the literary field's boundaries, distinguishing it from the economic and political fields: "By the second half of the 1880's, a group of prominent reviewers, many of whom were also novelists, had begun to agree that literary works should be judged as 'art' and not according to their popularity, market value, or moral worth" (435). In order to do so, these reviewers emphasized the "'harmonious' ideal of 'truth' - so that it could be used to describe the nature of the artwork itself rather than its effect" (447). Poovey argues that the literary field began to express this autonomy in about 1884 , the year in which the following took place: Walter Besant gave his famous

${ }^{11}$ Toril Moi gives a couple of reasons for this requirement in the following: "Bourdieu grounds any literary analysis on an immense array of social and cultural data. [...] This requirement causes huge problems for critics studying American and British literature. There is no existing body of Bourdieuian analyses of the relevant fields or institutions. Only the most intensive research can rectify this situation" (504-05). In the following, Pierre Bourdieu lists the types of social and cultural data required to reconstruct a particular instantiation of the literary field: "information about institutions - e.g. academies, journals, magazines, galleries, publishers, etc. - and about persons, their relationships, liaisons and quarrels, information about ideas and problems which are 'in the air' and circulate orally in gossip and rumour" (31-32). 
lecture titled "The Art of Fiction," James published his response to Besant's lecture (which was also titled "The Art of Fiction"), and Robert Louis Stevenson published his own response to James's essay titled “A Humble Remonstrance” (442). According to Poovey, these three works signal the manifestation of an autonomous literary field because they represent the first concerted effort in Britain to express the notion that a literary work should be judged primarily on the basis of its merit as a work of art, and not simply on the basis of, for example, its popular appeal or its ability to effect moral change (448).

And while the three essays referred to by Poovey may be thought to reflect a broad range of opinions about literary art - a range that includes questions of morality all three take for granted the idea that these questions be framed, first and foremost, within a primarily literary context. ${ }^{12}$ Poovey illustrates this idea by analyzing the reception history of the novelist Charles Reade, whom she describes as one of the most prolific authors in Victorian England. According to Poovey, Reade was dispossessed of a place within the literary field - and eventually the British literary canon - because he was not willing to consistently frame his work in this artistic context. ${ }^{13}$ Rather, Reade

\footnotetext{
${ }^{12}$ Accordingly, Besant opens his lecture by stating, "I desire to consider Fiction as one of the fine arts" (3). In his own essay, James expresses delight at Besant's desire and hails him as a fellow member of the "brotherhood" (855) that is the newly-liberated literary field: "It is excellent that he should have struck this note, for his doing so indicates that there was need of it" (857). Furthermore, because James litters his essay with French expressions, and takes on an explicitly French tone (Walton 33), he demonstrates both that he views the British literary field as having its roots in French culture, and that he wishes to take a certain amount of credit for having used the French example in order to contribute to the liberation of the British field.

${ }^{13}$ Poovey writes, "As an effect of this agreement [that is, the concerted effort between Besant, James and Stevenson], which can be dated, symptomatically at least, to 1884 , some kinds of writing that had previously been valued were devalued, then cast out of the literary canon. This, of course, was the fate of Reade's novels" (442).
} 
inadvertently compromised his immortality by describing his own work as a means of conveying facts: "Reade was adamant that one could not distinguish between facts and fiction and that, far from leading away from the truth, facts paved the royal road to this goal" (444). On the other hand, James was able to stake a place within the British field and literary canon because he was indebted to the project of developing the idea that his own works - which were presented as the artistic standard that any literary work of the period was meant to achieve - were organic wholes that existed according to a distinct artistic logic. As a writer, critic and theorist, James was not only a participant in the British literary field, he also exercised his literary prestige in the guise of a cultural commentator to establish for the field the same autonomy it had gained in France.

One of the ideas suggested by Poovey's work is that the late-Victorian literary field operated according to dynamics similar to those governing the French field of the same period. This means that James's position within the British field can be roughly determined by using as a basis the permutation of the French field described by Bourdieu in "The Field of Cultural Production" (Figure 1). In addition, Poovey's work shows that James took advantage of this burgeoning autonomy by attempting to dictate the new literary standard, and thus the rules by which the newly-liberated literary field would operate. Accordingly, Poovey suggests that James's position in the British field is homologous to Flaubert's within the French one. For Bourdieu, Flaubert existed in a position between the dominated pole of social art and the dominating pole of bourgeois art (199). The artists in the former position "demanded that literature fulfill a social or political function" (Bourdieu 198), while those in the latter used their work to reflect to the bourgeoisie their own values, thereby contributing to the maintenance of those values 
(Bourdieu 199). In order to distinguish themselves, the artists outside the two camps for example, those like Flaubert - had to invent what was called "art for art's sake" (199). This position expressed itself with the idea that the work of art should be judged as such, and not as a moral expedient or market good. David A. Cook suggests that Henry James's increasing affinity with Flaubert (and others who occupied this position) is exemplified in James's numerous evaluations of Madame Bovary: “Between 1874 and 1902, James wrote four separate essays on the work of Gustave Flaubert, in each of which he attempted to comprehend Flaubert's achievement through Madame Bovary" (289). Cook argues that with each of these successive essays, James evaluated this work less on moral grounds and more on an aesthetic basis (306). Eventually - that is, towards the end of James's career - the author finally came to accept Flaubert "on his own aesthetic terms, because, as James then wrote, 'the more we take him as he is the more he has a special authority"' (Cook 305). James's evaluation of Flaubert echoes the type of criticism espoused by the members of the art-for-art's-sake camp, which identifies the autonomy of the artistic work as a prerequisite for both literary value and the authority of the literary agent. Thus, within the British literary field, James can be tentatively and preliminarily placed in a position analogous to Flaubert's position within the French field because, like Flaubert, he was a progenitor of his respective field and increasingly emphasized aesthetic aspects of literary works as his career progressed.

According to Bourdieu, in order to maintain a position atop the hierarchy of the literary field's autonomous subfield, authors such as Flaubert had to expunge from their works all indicators that could serve to associate them with any but the most purely literary positions in the field. Bourdieu writes, "What made Flaubert so radically original 
and what confers on his work an incomprehensible value, is his relationship, albeit negative, with the whole literary world in which he acted and whose contradictions and problems he assumed absolutely" (205, emphasis of "negative" added). For Bourdieu, Flaubert's works - specifically Madame Bovary and Sentimental Education - exhibit not the positive force of individual genius, but the painstaking construction of a position within the field that bears a thoroughly negative relation to all other prescribed positions. As Bourdieu explains, "He was indeed putting himself in an impossible situation, and in fact, the whole time he was working on Madame Bovary, Flaubert never stopped talking about his suffering, even his despair" (204). Bourdieu also contends that this meticulous act of position-taking manifests itself textually in Flaubert's unique style (210). In addition to its stylistic effects, the strategy had a significant narratival one, which was the effacement from the text of any explicit reference to a narrato-authorial subject: "It is here, in this narrative with no beyond, in this narrative that recounts itself, in the irreconcilable diversity of its perspectives, in the universe from which the author has deleted himself but remains [...]- it is here that we find Flaubert's point of view" (Bourdieu 211, emphasis added). Through his painstaking attempt to uphold a position atop the autonomous sub-field's hierarchy, Flaubert effaced from the text any distinct, univalent reference to himself - that is, in order to not be identified with any one of the established positions in the literary field - thereby laboriously carving out a more strictly literary position.

Thus if James and Flaubert are homologues, it follows that the Jamesian text works toward establishing, and then maintaining, James's position atop the hierarchy of the autonomous subfield. And while only a limited number of Bourdieuian readings of 
James have been published, ${ }^{14}$ the idea that the author's literary autonomy gets expressed at the narrative level is not novel, but has been implicitly asserted by a number of critics. Indeed, the degree to which these critics echo Bourdieu's reading of Flaubert is striking. For example, Bradley Deane suggests that James's texts exhibit the negativity and authorial absence that signal a striving for literary autonomy, evoking this in the following: "If James's narrative absence is a form of death, it does not so much imply his inconsequence as it does his empowered transcendence" (109). Deane continues on to figure James and Flaubert as coequals in their striving for such transcendence: “James's well-known praise of Flaubert's impersonal style may thus be read as a program for his own authorial performance" (109-10). But this critical opinion dates back much earlier than Deane's work, and can be said to form the very basis of Anglo-American narrative theory. Writing in 1955 - well prior to the emergence of the form of literary sociology exemplified by Bourdieu and Deane - Norman Friedman outlined the narrative techniques by which James obscured references to his authorial self. Friedman argues that it is the technique of limited point of view described by Lubbock that allowed James to achieve this effect. Friedman expresses this idea by quoting Warren Beach: "This is the great outstanding feature of the technique since the time of Henry James,' claims Beach, 'that the story shall tell itself, being conducted through the impressions of the characters. It is this which finally differentiates fiction from history"' (1160). This

\footnotetext{
${ }^{14}$ Apart from Poovey's essay, to my mind, there have only been two such works published, and both in Izzo and Martinez's Revisionary Interventions into Henry James. These are Donatella Izzo's "More Lessons from the Master: Henry James and the Literary Field" and Manuela Vastolo's "In the Cage of Class." The former is most pertinent to the current thesis, as it reads James's works in the context of the literary field (specifically in reference to literary autonomy); the latter deals primarily with James and Bourdieu's concept of habitus.
} 
quotation is particularly salient for the way in which it explicitly and unambiguously conflates the literary technique of limited third-person point of view with a social striving for literary autonomy. Thus to summarize the implicit conclusions of Beach, Friedman, and Deane using Bourdieuian terminology: the technique of limited point of view that is exemplified in The Ambassadors is the strategy by which James effaced any traces of explicit textual reference to an authorial subject, thereby maintaining the negative relation between the position of its author and the other positions within the British literary field. To position James according to this trajectory would be to figure him in the following way: James set the rules for the British field's autonomous subfield around the year 1884; after this - and in order to maintain his place atop the hierarchy - he progressively qualified these rules through constant refinements to his stylistic and narrative techniques. According to this trajectory, the late phase marks the culmination of this process, as exhibited with its complex works that consistently obfuscate authorial identity and thus mark the perfection of the technique of limited point of view.

But is this really James's position-taking strategy? Donatella Izzo argues otherwise, suggesting that it is a mistake to conflate, from a Bourdieuian perspective, the authorial images of James and Flaubert. Izzo writes, "far from thinking of his calling as a sacred precinct secluding him from social life, [James] took it [...] as the ground of his moral authority as a full-fledged intellectual in the public sphere" (75-6). According to Izzo, James's work is not to be defined strictly by way of its negative relation to the various positions within the literary field; rather, she sees the Jamesian text as exhibiting positive moral features. Without following up on the idea that James's position-takings are guided by a moral principle, the remainder of the current chapter will proceed on the 
basis of Izzo's idea that James exists in a position other than the strictly autonomous one. It will also proceed with the assumption that, as James's implied position has been shown to affect interpretations of the narratival features of his texts, more accurately identifying this position promises to refine the proposed reading of the spatio-temporal thread running through The Ambassadors. In order to locate this more nuanced position, it will pay to recognize an observation made by Jacques Dubois: "it may be noted that biography, long discredited in literary studies, is making an interesting comeback in social history, not as a simple accumulation of insignificant facts, but as a constructed biography aimed at reconstituting the logical processes behind the actions of the subject within a field" (94). So while a Bourdieuian analysis of late James is inhibited by the amount of time and effort required to reconstruct the Late-Victorian literary field, it is on the other hand facilitated not only by the homologies between its own structure and that of the French field of the same period, but also by the inordinate amount of biographical work published about Henry James (Leon Edel's five-volume biography The Life of Henry James is just one example of this abundance). In what immediately follows, such work will be analyzed in order to develop a more refined picture of the position-taking act implied by The Ambassadors.

In order to place this biographical information in a Bourdieuian context, such information will be interpreted in reference to the relationship between economic and literary autonomy. In "Flaubert's Point of View," Bourdieu draws a close connection between these two types of autonomy:

In this anti-economic economy fixed at the pole that was economically dominated but symbolically dominant - with Baudelaire and the Parnassians for poetry, with 
Flaubert for the novel - producers could end up, at least in the short term, with only their competitors for customers. "Bourgeois artists" were assured of an immediate clientele. The producers of commercial literature who worked on commission [...] could live well off their earnings and at the same time earn a secure reputation as socially concerned or even socialist (like Eugène Sue). Quite to the contrary, the tenants of pure art were destined to deferred gratification. [...] It was in effect an upside-down economy where the artist could win in the symbolic arena only by losing in the economic one (at least in the short term) and vice versa. (201)

According to Bourdieu, the characteristics of the autonomous artist are expressed not only on the discursive level, but on the monetary level as well. The ascendant autonomous position is a luxury afforded by an independent income because it is important that the producer avoid the smutch of pecuniary grasping in order to maintain this position. Thus, professional writers - that is, writers who rely overly on their literary output for their income - need not apply to the position of autonomous producer. This fact explains the import behind the following comment by Théophile Gauthier: "Flaubert was smarter than us... He had the wit to come into the world with money, something that is indispensable for anyone who wants to get anywhere in art" (qtd. in Bourdieu 68). In short, the position of absolute literary autonomy is one that has to be purchased with a good deal of both symbolic and monetary capital.

Judging from some of the conclusions of the previously mentioned biographical works, James was not particularly disposed to inhabit the autonomous position. In his book Friction with the Market (1986), Michael Anesko has produced a detailed history of 
James's career as a publishing author. ${ }^{15}$ In it, Anesko paints a picture of an author who was subject, from very early in his career, to the appeal of literary profits. Anesko argues that this predilection began to develop in James when he was forced at a young age to define himself in negative relation to the literary agent of his father, Henry Sr.: "Despite the fact that his father applied himself at his writing table with 'regularity' and 'piety' ('as if he had been working under pressure for his bread and ours'), the exercise of the elder James's 'remarkable genius brought him in fact throughout the long years no ghost of a reward in the form of pence"" (31). Anesko goes on to argue that not only was the image of the diligent and unremunerated father a negative influence on the young author, it was also a point of embarrassment that the elder Henry actually paid to have his writing published: "While James can admire the purity of his father's motives, he also feels a kind of professional embarrassment over the circumstances by which the paternal philosophy found its way into print. For not one of a dozen books by the senior Henry James would a publisher assume the risk of plates and paper - hardly an auspicious precedent for his son's literary ambitions" (31). In his biography of Henry James, Leon Edel represents the dynamic between the three eldest males in the James family - Henry Sr., William, and Henry Jr. - as one largely determined by Henry Sr.'s financial independence and consequent lack of employment (1:52). Suggested by this dynamic is the idea that Henry Sr. expressed an ineffectuality and moral looseness, while William, the consummate Harvard professional, struck out for the pragmatic antithesis of the paternal example, and Henry Jr., taking up an artistic profession, exemplified the synthesis of the pragmatic brother and the religiously and professionally ambiguous

\footnotetext{
${ }^{15}$ For other analyses of James's relationship to the monetary, see Agnew, Meissner, and Rose.
} 
father. According to this representation, it was crucial that Henry Jr. be paid for his work in order to distinguish himself from his father. Thus, if a prerequisite dispositional quality of the autonomous producer is a freedom from the market and the need for prompt remuneration, the disposition engendered in James by way of his relationship to the male members of his family made the author a problematic candidate for this position.

But if 1884 marks the birthday of the literary field in Britain - an emancipatory process in which James played an integral role - it could also be said that this date signals the mitigation of James's pecuniary drive. According to records of James's literary income, 1884 was a watershed moment in his literary career, as his income began to approach here, for the first time, the five-digit mark (see Figure 2). And as this annual income had shown steady increases since the beginning of the author's career, it could be argued that James wrote "The Art of Fiction" with a sense of increasing financial independence. In this sense, James was pleading for literary autonomy at the very point and precisely because - he had a strong feeling of financial autonomy. But what these records also demonstrate is the extent to which the author was dependent for his income on serial publication. According to Michael Anesko, "Excepting the years of his active engagement with the theatre (1893-95), only twice before 1900 did James's income from book sales and advances exceed his receipts from periodicals, and both of these instances were exceptional" (168). If James developed a feeling of financial freedom with the maturation of his career, this feeling was no doubt overshadowed by the fact that it was the product of his enslavement to the serial publication industry. Indeed, one of the only times in James's career when his book sales exceeded his take-home from magazine 


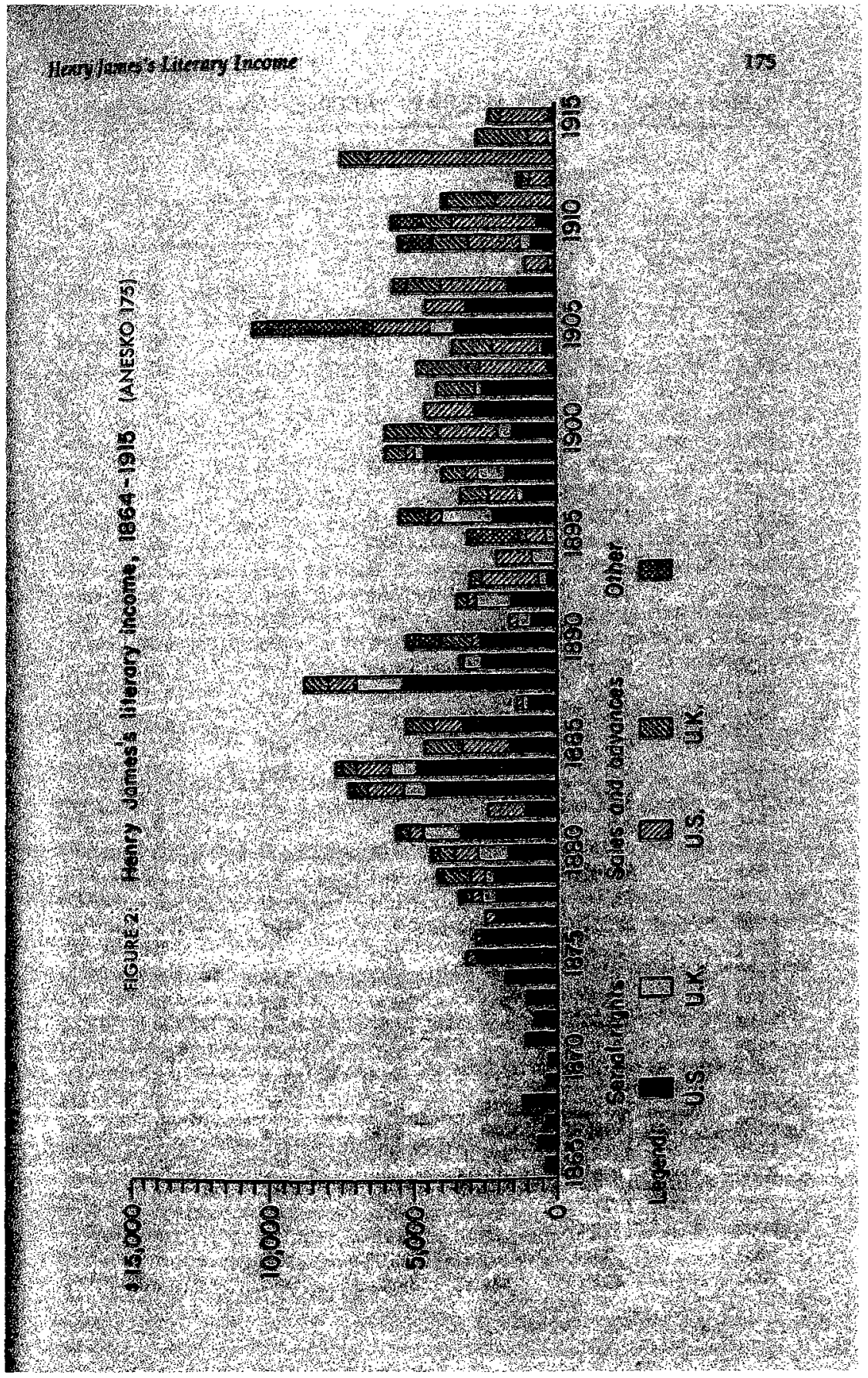


contributions was the year 1885 , this being due to "the fact that he was not paid for the serialization of The Bostonians, because of the bankruptcy of his American publisher" (Anesko 169). As Anesko points out, a similar deviation occurred during the period from 1893-95, when James directed much of his efforts to writing stage plays. During this stretch, James's contributions to periodicals all but ceased, suggesting that the author attempted to escape the captivity of the periodical publication industry, and establish a place in the relatively independent realm of unserialized novel publication, by using the theatre as a springboard.

But there is no need to speculate about whether or not James's move into the theatre was a pecuniary one; the author himself was more than willing to admit the fact. Moreover, James figures it as a move tailored to give him the financial freedom to eventually assume the coveted position of autonomous artist. In the following, Leon Edel summarizes one of the many correspondences in which James explained to his friends the strategy associated with his move into the theatre:

He explained his plan to bridge art and the marketplace in precise terms to [Robert Louis] Stevenson, who by now was in the South Seas. On the one hand he announced to him that he would cease to write long novels and would concentrate on shorter fictions, thereby freeing himself for play-writing. On the other he spoke of his plays as a means by which he would free himself to produce fictional masterpieces. (267)

It is significant that the letter referred to here was written to a literary friend - a fellow member of the British field and one its liberators. James is careful to distinguish between his literary self (the producer of masterpieces) and the alter ego who makes a foray into 
the theatre - an act that is referred to by his literary persona as a kind of artistic slumming (Edel, The Life 3: 267). Indeed, he "apologizes right and left for going into the theatre, feeling that as an artist he is soiling his hands by so much worldliness and so much involvement with the values of the marketplace" (Edel, The Life 3: 282). In a sense then, his foray into the theatre and his correspondence are part of an overall strategy within the literary field: to accrue the funds necessary for literary autonomy while concurrently disassociating himself from the taint - lethal to the autonomous artist - of mercenary grasping.

But it is well known that James was unable to attain financial success in the theatre, as the profits he took from this venture - while he expected them to be exponentially larger than those from his serial publications (Edel, The Life 3: 283) - were in fact far smaller than his serial receipts per annum (Anesko 175). How, then, did this theatrical failure affect his position-takings in the phase of literary output that immediately followed his theatrical foray (his so-called "major phase," of which The Ambassadors is a part)? One version of this strategy has James resigning himself to serial publication while beating back the mercantile taint associated with such work with a more rigorous emphasis of his obscure style and authorless narrative techniques. But at bottom of this hypothesis is the idea that we should take James at his word when he says that he desired, with his theatrical venture, to liberate himself from the marketplace. As Michael Anesko writes, "James's calculated attempt to avoid both the din of commercialism and the silence of oblivion betrays a characteristic tension between his honest desire for success and a fear of appearing too clamorous for the tangible rewards that the marketplace could confer" (11). Anesko thus claims that the monetary was, for 
James, not an artistic expedient, but rather, symbolic of public acknowledgement. He then goes on to describe James's relationship to serial publication as a triangular one in which his publisher buffered him from his audience (25). In this sense, James's work was "accepted" not by a consuming audience that represented the literary marketplace, but by an agent one step removed from this marketplace. For example, if the publisher agreed to print James's work, it did not necessarily mean that the public consumed these works in depth; it could also mean that the works gave the magazines the mere superficial air of refinement. And as the serial format was the collaborative work of a number of authors, a positive circulation attained through this conduit did not necessarily reflect positively on the author himself. Thus serial success was for James an attenuated form of success. And his foray into the theatre was not strictly a means of escaping the marketplace - the arena of evaluation in which the common consumer was arbiter. Because the theatrical arena was one of direct communication with the audience, it was rather a way of more directly participating in this marketplace.

It is thus significant that James represents the theatrical venture to his literary friends as an artistic expedient, while to his family he figures it as a way of achieving public recognition and glory. Writing to his sister Alice he describes one of his few theatrical successes in the following way:

It was really beautiful - the splendid success of the whole thing [...]. The attention, the interest, the outbursts of applause and appreciation hushed quickly for fear of losing... what was to follow, the final outbreak at the end for "author, author, AUTHOR!" in duly delayed response to which, with the whole company 
grinning delight and sympathy (behind the curtain) I was led before... to receive the first "ovation," but I trust not the last of my life. (qtd. in Anesko 21) If it was not the last, it was very nearly. But the ecstasy with which James received this applause suggests that he was being somewhat disingenuous when he expressed to his literary friends the shame of being reduced to the position of playwright. The two types of correspondence - familial and literary - thus represent James's competing artistic inclinations, and the degree to which James was both well disposed and utterly not disposed to inhabit the position of autonomous artist. If a requisite for literary autonomy is the ability to represent the work of art as an organic whole that begs to be appreciated with a rigorous literary-critical discourse, then James fit the bill perfectly. But if it relied on freedom from the marketplace, and both a financial and personal disposition towards delayed gratification, then the author exposed himself as (practically by nature) unsuited for the position: James both required a steady income and craved gratification in the form of public attention.

Thus a representation of the position-takings implied by The Ambassadors must recognize both of these competing dispositions. We have already seen that the author's inclination toward autonomy is textually manifested in the form of his characteristic technique of limited point of view. Percy Lubbock writes that this technique allows the author to withdraw "to let Strether's thought tell its own story" (156). Jonathan Friedman argues that, in The Ambassadors, "Mental awareness is thus dramatized directly instead of being reported and explained indirectly by the narrator's voice" (1165). And Wayne Booth writes, "the effect of The Ambassadors is much closer to that of the great firstperson novels, since Strether in large part 'narrates' his own story, even though he is 
always referred to in the third person" (150-1). All three of these theorists implicitly argue the same point: that a strong, independent narratorial subject - one that is synonymous with the authorial subject - is not on display in The Ambassadors. By denying the author an expressive part in the text, these theorists portray him as wishing to buffer himself from his consuming public with an art form that does not bear a personal, authorial trace. And while Gérard Genette provides an amendment to these theories, arguing that it is impossible to have a narrator-less narrative (164), ${ }^{16}$ by distinguishing between mood and voice, seeing and speaking, person and perspective, he represents the Jamesian text as one that has a diminished narratorial presence with his formula: information + informer $=\mathrm{C}$. This formula "implies that the quantity of information and the presence of the informer are in inverse ratio, mimesis [or dramatic narrative] being defined by a maximum of information and a minimum of the informer, diegesis [or narratorial discourse] by the opposite relationship" (Genette, Narrative 166). As such, it represents two notable approaches to mimetic narrative: "these two cardinal precepts of showing: the Jamesian dominance of the scene (detailed narrative) and the (pseudo-) Flaubertian transparency of the narrator" (Genette, Narrative 166, emphasis in the original). By downplaying the role of the informer and emphasizing the importance of information, James and Flaubert construct a narratival indicator of autonomous

${ }^{16} \mathrm{~J}$. Hillis Miller expresses this idea more strongly when he writes, "Such terms [as focalization and point of view] elide the way the essential mode of existence of any literary fictional work is linguistic through and through. There ain't nothing there but words" (125). 
production: a diminished narrato-authorial presence. ${ }^{17}$ Thus, to appreciate the Jamesian text as it has been framed throughout the history of Anglo-American narrative theory, ultimately via Genette, would be to confine James's contributions to the concept of narrative mood, thereby emphasizing his autonomous disposition and forfeiting any attempt to recreate a substantive authorial subject from what are only scant narrative traces.

But this is only half of the story. On the other hand, how does James's alternate disposition towards public recognition get represented? No doubt, it is by one of the other components of Genette's paradigm - one of the chapters in Genette's text from which James has (for suspect reasons) been debarred. J. A. A. Amoros isolates the aspect of narrative most associated with authorial subjectivity when he writes, "when James does mention the specific speaker of one of his tales side by side with its specific observer or transitive centre, he unabashedly depicts himself as entirely responsible for the words uttered" (51, emphasis added). Thus, for Amoros, mood in James represents a non-authorial entity, while voice represents the act of authorial narration. ${ }^{18}$ It can thus be argued that the split between the autonomous and heteronomous dispositions is expressed

\footnotetext{
${ }^{17}$ Not only does Genette conflate James and the Jamesians in an attempt to distinguish himself from the Anglo-American school, he apparently wishes to link James and Flaubert in order to emphasize the narratological preeminence of the text upon which he has chosen to focus his study: Proust's Recherche. Thus, for Genette, the texts of James and Flaubert are one-dimensional in that they represent information at the expense of the informer, while Proust's has a two-dimensional quality in that it is (somewhat heroically) able to represent both aspects in equal prominence (Genette, Narrative 166-8). ${ }^{18}$ While Amoros is apt to acknowledge the existence of these two components in Jamesian narrative, he assigns Jamesian mood and voice to distinct ontological realms. As such, mood exists at the narrative level while voice exists in the realm of the biographical author (Amoros 51). In contrast, this thesis is dedicated to figuring Jamesian voice as a concept that exists very much at the level of narrative, as well as to straddling the two levels upon which Amoros's distinction is based.
} 
at the level of narrative with the split between narrative mood and narrative voice. That is, if the category of narrative mood signifies James's attempts to compose an authorless narrative, and thereby effect autonomous status, it follows that by promising to linguistically represent an authorial presence, the enunciating instance that falls under the category of narrative voice represents the heteronomous, attention-seeking Jamesian disposition. And while Genette precludes the conflation of the narrator and author, he does allow for a type of narrative that breaks the rule implied by the formula information + informer $=\mathrm{C}$; that is, one that exhibits both a maximum of showing and a maximum of telling: "Proustian narrative consists on the one hand almost exclusively of 'scenes' [...], in other words, of a narrative form that is most rich in information, and thus most 'mimetic'; but on the other hand [...] the narrator's presence is constant, and so intense to be completely contrary to the 'Flaubertian' rule" (167). Indeed, as has already been determined, the misrepresentation of the Jamesian text on display in Genette's treatise is due to the fact that Genette inherited an overly mimetic text from the Anglo-American tradition. As Amoros suggests, because there is an authorial representative on display in the Jamesian text in the form of an enunciating voice, The Ambassadors promises to be both mimetic and diegetic, and, as an extension, both autonomous and heteronomous. But how does one narratologically represent the heteronomous, authorial component of the Jamesian text - that is, the narrative voice - given that Genette dismisses any substantial connection between the narratorial voice and an authorial subject (Narrative 213)? Before addressing this question, it will pay to first assess James's own understanding of narrative voice. 
James provides some clues for conflating his own narratorial and authorial voices in the final paragraphs of his New York Edition preface to The Golden Bowl. ${ }^{19}$ In these pages, James expresses the wish to be identified with his fictional work: "We are condemned $[\ldots]$ whether we will or no, to abandon and outlive, to forget and disown and hand over to desolation, many vital or social performances [...]. Not so on the other hand our really 'done' things of this superior and more appreciable [that is, literary] order [...]. Our relation to them is essentially traceable, and in that fact abides, we feel, the incomparable luxury of the artist" (348). But not only is it James's desire to be identified with his work - that is, in the way that the autonomous producer is identified with the finished literary product and not with any one of the points of view or opinions expressed within the narrative; as James claims here, it is also his wish to be identified in it, given that he expresses delight at the fact that the connection between the work and the artist is "traceable" in the text. But what kind of trace is this? James discloses what he is referring to here when he writes, "It is scarce necessary to note that the highest test of any literary form conceived in the light of 'poetry' - to apply that term in its largest literary sense - hangs back unpardonably from its office when it fails to lend itself to vivâ voce treatment" (346). Vivâ voce: with living voice. James elaborates on this notion: "The essential property of such a form as that is to give out its finest and most numerous secrets, and to give them out most gratefully, under the closest pressure - which is of course the pressure of the attention articulately sounded" (346-47, emphasis in the original). If the prefaces are, as John Pearson argues, James's attempt to teach the reader

\footnotetext{
${ }^{19}$ The preface to The Golden Bowl is the last in the series of eighteen New York Edition prefaces. These quotations have been taken from the last - and thus most conclusive and overarchingly theoretical - paragraphs of all the prefaces.
} 
to read his fiction (13), the author can be imagined as using this passage as a means of pleading to the reader to echo the living voice that leaves a trace throughout his fictional work. And with the phrase "the attention articulately sounded," James signals that this vocal trace is also a spatio-temporal structuring element. That is, by conflating the psychological faculty of attention and this vocal trace in a single conceptual object, James gives voice the temporal duration of an act of continuous attention. And not only does voice gain a temporal quality through its relation to the author's faculty of attention, it also gains a heteronomous quality, given that attention was a highly valued bourgeois virtue in late-nineteenth century Western culture. It is thus conceivable that James's heteronomous disposition manifests itself on the textual level in the form of a traceable narrato-authorial voice, one that serves as proof that the author possesses the bourgeois virtue of sustained attention. It is furthermore conceivable that this is the spatio-temporal thread running through The Ambassadors: the voice of the constantly attending narrator. Thus, when the author pleads to the Duchess of Sutherland to keep hold of the thread running through the text, he is beseeching her to recognize his possession of this virtue by articulately sounding his traceable and constantly attending voice. In short, he is pleading for the same recognition that the bourgeois play-going audience bestows on him with their so-audible exclamations of approval. James seems to say to the Duchess, "I am the narrator; will you not be my narratee ${ }^{20}$ by constantly attending to me as I constantly attend to my narrative, and, in so doing, prove that you have done so by echoing my own proof, which is the vocal trace that I have left?"

\footnotetext{
${ }^{20}$ In the glossary to Phelan and Rabinowitz, the term "narratee" is defined in the following way: "the audience directly addressed by the narrator" (548).
} 
Granting that James chose to emphasize his own virtue of sustained attention by leaving a vocal trace through The Ambassadors, it is important to look at a brief history of this virtue in order to get a sense of the way in which - or the narratological mode by which - he did so. ${ }^{21}$ In so doing, we will inch closer to a decisive answer to the question, What does Jamesian narrative want? It must first be noted that the type of attention that James is pointing to in the letter and the preface is best described with the term "sustained voluntary attention." As a bourgeois virtue, sustained voluntary attention is a concept that signifies two key qualities: the word "sustained" identifies it as focused on a single object over a given period of time, and the word "voluntary" identifies it as a function of the free will of the attending subject in the sense that the subject has the power to choose whether or not to attend a given object. In a study of the history of this bourgeois virtue, Michael Hagner claims that while sustained voluntary attention attained a particular importance in late-nineteenth-century Western society, it has its roots in Enlightenment philosophy. Hagner writes, "It is precisely this connection that is the common denominator in the growth of attention: it becomes an instrument in education and the development of the individual, and therefore a bourgeois virtue. To exaggerate and generalize, one could say that the moment reason becomes important, so does attention" (673). Hagner begins his brief cultural history of attention with an explication of these eighteenth-century roots. He states that the ability to fix one's attention became a virtue in this period (672), and continues on to illustrate the power that this virtue was thought to grant its possessors by citing an anecdote first retailed in 1794 by the English physician and naturalist Erasmus Darwin:

${ }^{21}$ For other analyses that relate nineteenth-century literature to attention as a social and cultural phenomenon, see Arata, Dames, Laufer, and Stougaard-Nielsen. 
Darwin reported on a sudden occurrence of collective sea-sickness somewhere in Scotland: “... a sudden change in the wind shook the undistended sail, and stopt our own boat; from this unusual movement the passengers all vomited except myself. I observed that the undulation of the ship, and the instability of all visual objects, inclined me strongly to be sick; and this continued or increased, when I closed my eyes, but as often as I bent my attention with energy on the management and mechanism of the ropes and sails, the sickness ceased; and renewed again as often as I relaxed this attention." (678)

Here, Darwin represents his own faculty of sustained voluntary attention as a Herculean quality, using it to distinguish himself from the otherwise indistinguishable mass of humanity aboard the ship. Writing almost one hundred years later, William James makes a similar association between the power of sustained voluntary attention and personal virtuosity, in this example linking the outward manifestations of such attention to the inward quality of genius: "an intellect unfurnished with materials, stagnant, unoriginal, will hardly be likely to consider any subject long. A glance exhausts its possibilities of interest. Geniuses are commonly believed to excel other men in their power of sustained attention" (423, emphasis in the original). Thus, by inscribing in The Ambassadors his own powers of sustained voluntary attention, and then pointing to this textual inscription with the preface to The Golden Bowl and the Sutherland letter, Henry James is espousing a long-established bourgeois virtue, associating that virtue with his public image as a literary agent, and thereby betraying his Bourdieuian heteronomy.

But the question that this conclusion immediately prompts is the following one: Why is Genette's concept of narrative voice - a concept that represents a stripped-down 
version of the narrating subject whose only subjective qualities are those determined through his or her relationship to the narrative - the best one with which to represent the glory-seeking author who stands on stage, après-théâtre, in subjective prominence, with chin held high and chest inflated? That is, why is the authorial trace left in the text in the form of a proto-narratological soft voice, and not the booming and self-referencing intonations of an embodied, omniscient Victorian narrator? One obvious reason for the attenuated textual existence of the narrato-authorial subject is that it was the only way for the author to achieve, like Flaubert, consecration in the autonomous sub-field; but another (indeed corresponding) reason is that by the late-nineteenth century, sustained voluntary attention - while still very much a bourgeois virtue - was thought impossible to maintain by the physiological (that is, the physio-sensorial) subject. ${ }^{22}$ Hagner writes, "Precisely at this point attention became a problem. Until then, voluntary attention was supposed to make us the masters of ourselves. Now, however, the type of attention apparently controlled by the will ceased to offer any guarantees, since changes occurred even when one wanted to concentrate on an impression" (680). Put most simply, sustained voluntary attention - a concept that connotes self-mastery and linearity - was being considered impossible given that physiological research into attention was discovering strong correlations between the faculty of attention and the body's circulo-respiratory functions that connote both automation and the bi-linearity of advance and retreat. Writing in 1901, J. W. Slaughter elicits this idea:

The general results of our experiment would show, then, that the fluctuations of the attention are in close connection with at least three physiological rhythms.

\footnotetext{
${ }^{22}$ For a history of the use and evolution of attention metaphors in psychological writing, see Fernandez-Duque.
} 
That in most subjects they run parallel to the Traube-Hering waves of blood pressure, as Exner has suggested might be possible. That in some subjects the breathing undoubtedly plays the predominant role, and that in one subject it is probable that there is still another longer wave that assumes the more important place. (330)

Writing in the same year, Gustav Spiller evokes a similar notion in the following: "we may say that as the blood is propagated, not in a steady stream but in waves, so in attention, or neural functioning, advance proceeds by pulsations" (511). ${ }^{23}$ And although William James identifies a heightened faculty of sustained attention as a signal of genius, he undermines this mythology by identifying the intellectual object upon which so-called sustained attention is focused not as a coherent, singular object, but rather as a plural one made up of a series of distinct objects: "note that it is not an identical object in the psychological sense, but a succession of mutually related objects forming an identical topic only, upon which the attention is fixed. No one can possibly attend continuously to an object that does not change" (420-21, emphasis in the original). ${ }^{24}$ Thus, while the ideal image of sustained voluntary attention takes the shape of time's arrow, and implies masterly focus on a single object, the scientific reality of this type of attention that was

\footnotetext{
${ }^{23}$ See also Shand.

${ }^{24}$ This idea is expressed in another connection in Théodule Ribot's Psychology of Attention. Ribot writes, "There are two well-defined forms of attention: the one spontaneous, natural; the other voluntary, artificial. The former - neglected by most psychologists - is the true, primitive, and fundamental form of attention. The second the only one studied by most psychologists - is but an imitation, a result of education, of training, and of impulsion. Precarious and vacillating in nature, it derives its whole being from spontaneous attention, and finds only in the latter a point of support. It is merely an apparatus formed by cultivation, and a product of civilization" $(2$, emphasis added). Ribot thus expresses the new problem of attention by writing that voluntary attention (which once connoted continuity and the power of the will) is "[p]recarious and vacillating in nature."
} 
constructed through late-nineteenth century psychological experimentation and discourse reflected the pastiche of bricolage and the syncopated rhythm of the systole and diastole. And whereas in 1794 Erasmus Darwin was able to explain his self-control as a function of his ability to attend continuously to something other than the undulating motion of the sea, he would have had to amend his explanation in the context of late-nineteenth century psychology, given that the rhythms of embodied attention were being figured by this time as a reduplication of the bi-directional nautical rhythms. In order to exhibit the bourgeois quality of sustained voluntary attention, and thereby express his heteronomous disposition, Henry James thus had to address the new physiological facts of attentional experience. $^{25}$

Indeed, it will be shown in the following chapters that the way in which James achieved this bourgeois virtue on the narrative level is analogous to the way in which experimental psychologists did so in the lab: by setting up a dualistic inter-subjective dynamic in which desultory, physiological attention is displaced onto the subject of investigation, and disembodied, unilinear, sustained voluntary attention is reserved for the investigator..$^{26}$ Of the experimental method and its ability to preserve the quality of sustained voluntary attention, Hagner writes, "It would be an underestimation of the

\footnotetext{
${ }^{25}$ As Ryan notes, James was very much aware of, and influenced by, William James's 1890 compendium of late-nineteenth-century psychological work, The Principles of Psychology (76). By figuring William James as a node that channeled and facilitated the various psychological insights that were being developed in both the United States and Europe at the end of the nineteenth century, Ryan suggests that a concomitant of Henry's familiarity with the text is that he was well exposed to the psychological discourse of the time in general (8).

${ }^{26}$ This accords with conclusions drawn by Richard Hocks, who argues that the relationship between late-nineteenth-century psychological discourse and the fiction of Henry James is a modal one - meaning that this discourse is, in a sense, enacted or performed at the formal level rather than expressed at the propositional level (4).
} 
sensory physiologists and psychologists to assume that they would conclude from this experiment [one that used physiological evidence to undermine conventional notions of attention] that involuntary and uncontrollable types of attention dominated the conscious sort. On the contrary, their roots in the bourgeois virtue of self-discipline extend to the realm of experimental practice" (680). He then continues on to describe the way in which experimenters preserved this virtue: "Sensory attention thus became a hybrid: on the one hand, its limitations and instability are subjects of experiments, on the other hand its practices and control are the basis of experiments. It is this latter ambivalence that appears to be one important reason for the countless experiments on attention in the last decade of the nineteenth century" (681-82). To explain this in reference to the aforementioned thread image: while advances in physiological science and the introspective method were constructing a human subject whose attention wavered in a motion that accorded to the rhythms of the circulo-respiratory system, the experimental psychologist - one of the subjective features of whom was the possession of an unrelenting clinical gaze - was allowed to maintain a unilinear spatio-temporal subjectivity that was based on the linear $\mathrm{x}$-axis of the record on which this individual was recording his or her clinical observations. That is, whereas the conclusions of the experimental method served to abolish the myth of the bourgeois virtue of sustained voluntary attention, the clinical mode of investigation that was set up by scientists to perform such demystification was a bastion in which this virtue could be preserved and monopolized by a clinician of limited physiological subjectivity. (Indeed, what becomes of experimental science if the scientist's ability to focus on, and document, his or her object of study is brought into question?) It is my contention that this type of clinical 
situation is what Henry James constructed when he composed The Ambassadors. Accordingly, the focalizing subject, Lambert Strether, is analogous to the subject under clinical study, while the narrating subject - the author's surrogate - is analogous to the clinician who is capable of preserving, in his or her privileged position, the bourgeois virtue of sustained voluntary attention. Furthermore, this narrating subject is constructed on the basis of a mitigated subjectivity (in the sense that it is not a physiological subject), because physiological metaphors were at the time used to signal - and were thus associated with - wavering attention. The notion of viva voce reflects this idea, as it identifies the authorial subject on display in the text not as a subjective whole, but as the vocal component of the authorial subject only. (That is, none of the author's heart, lungs, or "Traube-Hering waves" is traceable at the textual level; there is here merely an authorial voice that is able to reflect sustained voluntary attention, existing as it does in independence of these physiological counterparts). The plea to the Duchess of Sutherland is thus a plea to perceive this mitigated authorial subject by following the vocal thread of sustained voluntary attention as it weaves its way through the text. Ultimately, James is attempting to satisfy both his autonomous and heteronomous dispositions by inhabiting a subject position that makes a heteronomous virtue of the autonomous requirement of the author's attenuated textual presence. But that James has not been recognized as composing on the basis of both principles is due to the modesty and subtlety of the self-referencing textual trace he has left; however, this is not surprising, given that both the autonomous principle and the heteronomous principle that glorifies this particular bourgeois virtue demanded the attenuated textual presence of the literary agent. 
The next chapter will employ the bipartite methodological approach that has been set up thus far, which incorporates Genette's narratological paradigm and Bourdieu's sociological one, in order to identify the pseudo-bi-subjective-clinical-dynamic on display in The Ambassadors, and thus highlight the subtle textual inscription of the heteronomous principle. In itself, Genette's paradigm is particularly apt for this project, because - like the concept of sustained voluntary attention - it is structured on a spatiotemporal basis; because it is able to signify a narratorial subject of mitigated presence; and because it is able to represent, with its mood-voice distinction, the narrating instance as a relationship between two subjects. But as it has already been stated, because Genette's paradigm takes an agnostic or indeterminate stance toward the extra-textual (authorial) level, it will be necessary to refer to Bourdieu's concept of the literary field and the parameters of authorial subjectivity that it is able to construct - in order to fill in this extra-textual blank. Thus, the next chapter will begin by using Genette's paradigm to analyze the authorial subject that is inscribed in the narrative text; but when it reaches the extra-narrative point of indeterminacy that is indicative of Genette's paradigm, it will draw on the Bourdieuian component of the methodology to describe the narrato-authorial subject as a product of an extra-textual context. To reiterate a metaphor from the introduction, the next chapter will situate the text within the duck-rabbit warren that has been developed in the first two chapters in order to promote the cohabitation of the text's oppositional components: mood and voice, heteronomy and autonomy, and the textual narrator and the contextual author. 


\section{Chapter 3: Viva Voce, In Situ}

It was determined in the previous chapter that The Ambassadors is structured on the basis of two subjectivities which are best represented by the narratological concepts of mood and voice, and which are textual inscriptions of Bourdieu's autonomous and heteronomous principles, respectively. Importantly, it was also determined that these two subjectivities interact in the sense that the heteronomous vocal subject is constructed by way of his relationship to the autonomous focalizing subject, with this relationship eliciting the inter-subjective, late-nineteenth-century clinical dynamic. The current chapter will describe this relationship as it is inscribed in The Ambassadors by utilizing the relational and spatio-temporal characteristics of Genette's narratological paradigm. In short, it will expound on the nature of the text's two structuring principles by analyzing the relationship between the text's narrative and what Genette refers to as its narrating instance. It will also figure the narrato-authorial subject as attaining a unilinear spatio-temporal subjectivity as a result of this relationship. But while Genettean narratological analysis on its own inclines the analyst to figure the Jamesian text's narratorial subject as an attenuated, almost non-subjective, presence who merely serves the narrative and highlights the latter's relative importance, ${ }^{27}$ the Bourdieuian conclusions drawn at the end of the previous chapter will be brought to bear on this reading in order to identify the narrating subject as having substantive and contextually significant

\footnotetext{
${ }^{27}$ That Genette's narrator verges on being non-subjective is evinced by Mieke Bal's refinement - or logical extension - of this concept: "Bal - despite her keen interest in the ideological functions of narrative - opposed the current anthropomorphization of the narrator figure, marking the merely functional quality of the narrational instance with the impersonal pronoun 'it"' (Fludernik 42).
} 
subjective qualities. ${ }^{28}$ It will also be demonstrated in what follows that this relational and contextualized version of the text is best represented by an image that Strether uses to make sense of his own experiences: the figure in the clock at Berne. Accordingly, the circular path on which the figure moves reflects the circularity of the story; the truncated linearity of the exposed portion of this circle represents the linear, geo-temporal path that charts the course of the focalizing character's body; and this linear path represents the rigid spatio-temporal linearity of the narrator's discourse - what has been labeled viva voce. By moving through an analysis of the two narratological relationships, and into the extra-textual level of the literary field, the current chapter will move toward the identification of the spatio-temporal thread running through the text, which will be identified as the system of deixis that characterizes the narrating instance. This will pave the way for the description, in the fourth and final chapter, of the thread itself - which represents the narrato-authorial subject's possession of the heteronomous bourgeois virtue of sustained voluntary attention.

As it has already been suggested, Genette's paradigm is a tripartite one. Genette describes the three levels of his paradigm in the following:

Story and narrating thus exist for me only by means of the intermediary of the narrative. But reciprocally the narrative (the narrated discourse) can only be such to the extent that it tells a story, without which it would not be narrative (like, let

\footnotetext{
${ }^{28}$ This type of analysis roughly accords with Mark Seltzer's idea of the novel: "the novel does not simply refer to an 'extra-literary' history or politics that lies beyond it; nor is history merely a ground or background of the literary text. The movements of power do not lie in some hidden depths, but are visible on the surfaces of the literary discourse; and the historicity of the text is to be sought not in the grand designs and teleology of an absent History but in the microhistories and micropolitics of the body and the social body, in the minute and everyday practices and techniques that the novel registers and secures" (24).
} 
us say, Spinoza's Ethics), and to the extent that it is uttered by someone, without which (like, for example, a collection of archaeological documents) it would not in itself be a discourse. As narrative, it lives by its relationship to the story that it recounts; as discourse, it lives by its relationship to the narrating that utters it.

(Narrative 29)

Thus, narrative discourse is in one sense autonomous, ${ }^{29}$ with the textual vessel of the codex signifying this autonomy; but it is also dependent on outside sources, given that it cannot exist without referring to things on an extra-narrative level, such as a series of represented events and an enunciating subject. However, looking at things from the opposite angle, Grenette writes: "Story and narrative [...] exist for me only by means of the intermediary of the narrative" (29). That is, while both story and narrating are traceable in every narrative, they only exist to the extent that they are traceable. As an extradiegetic-heterodiegetic narrator, Henry James exists at the authorial level: he is the enunciator of a primary, framing narrative (extradiegetic) and he is not a character in the story that he narrates (heterodiegetic). ${ }^{30}$ This is another way of signifying the modesty of

\footnotetext{
${ }^{29}$ This word is being used in the non-Bourdieuian sense here. However, it is meant to suggest or connote the Bourdieuian definition.

${ }^{30}$ Regarding diegetic levels, Genette writes: "We will define this difference in level by saying that any event a narrative recounts is at a diegetic level immediately higher than the level at which the narrating act producing this narrative is placed. M. de Renencourt's writing of his fictive Mémoires is a (literary) act carried out at a first level, which we will call extradiegetic; the events told in those Mémoires (including Des Grieux's narrating act) are inside the first narrative, so we will describe them as diegetic, or intradiegetic" (Narrative 228, emphasis in the original). Regarding the distinction between hetero- and homodiegetic narrators, Genette writes, "The real question is whether or not the narrator can use the first person to designate one of his characters. We will therefore distinguish here two types of narrative: one with the narrator absent from the story he tells [...], the other with the narrator present as a character in the story he tells [...]. I call the first type, for obvious reasons, heterodiegetic, and the second type homodiegetic" (244-5, emphasis in the original).
} 
the narratorial trace in The Ambassadors (or the heightened presence of information and the limited presence of an informer). Because the narrator is not an intradiegetic one, the narrative does not include a framing narrator who could expound on this subject's characteristics; and because the narrator is not a character in the story, there is no way to elucidate this subject's characteristics through reference to his story-world counterpart. But as Gérard Genette admits, no narrative exists that does not provide at least some degree of information about its enunciator. And although the amount of such information might be slight in the case of The Ambassadors (Lubbock's idea that "Strether's thought tell[s] its own story" [156] is an indication of this), by acknowledging the conclusions drawn in the previous chapters, it will be demonstrated that, in the context of the latenineteenth-century literary field and psychological discourse, this small amount of information is able to speak volumes. The forgoing analysis of these two relationships will be conducted in order to demonstrate why, in the context in which the text has been situated thus far in this thesis, the mitigated presence of the narrato-authorial subject is not meant to signify this subject's absence, but instead a form of mitigated presence. In short, the little of James that is on display in the text - that, according to Genette, perforce must be on display - is not meant to signify this subject's absence from the text but instead a form of presence that thrives in mitigation. ${ }^{31}$ But before examining the

${ }^{31}$ In his essay, Dan Shen counters Genette's idea that such a thing as an extra-textual narrating instance can be gleaned from textual indicators of narration: "If we are to concern ourselves with the real process of narrating, we would have to go beyond the narrative into the real world" (124). He also writes, "in the case of written narration, the real process of narrating (i.e. writing) lies beyond the narrative, thus beyond the scope of any narrative classification, but it could fruitfully become a part of narratological study through combining intrinsic criticism with extrinsic criticism" (123). This thesis has set out to conduct such an intrinsic/extrinsic analysis by bringing together Genette and Bourdieu. 
narrato-authorial subject by way of its relationship to the narrative, this narrative will be elucidated by way of its relationship to the story.

Beginning with the story of The Ambassadors: Lewis Lambert Strether - a widower and "a man of five-and-fifty" from Woollett, Massachusetts (24) - is sent by his fiancée Mrs. Newsome to Paris to repatriate the latter's profligate son Chad Newsome, who has taken up residence amongst a coterie of expatriate artists. The ultimate goal of this repatriating mission is to put Chad at the head of the family's American manufactory. While Strether's objective is, on the surface, simply one of locating and escorting Chad back to Woollett, the matter is complicated - or calls for a certain amount of delicacy on Strether's part - because Chad is thought to have been "got hold of" by a wicked and debauched Parisian woman, Madame de Vionnet (59). Further complicating the matter and propelling much of the action is the fact that Strether is, as James describes him in the preface to the novel, "a man of imagination" (4). By promoting interpretative ambiguities, Strether's imagination causes him to be irresolute on matters of decision. His traveling companion Waymarsh summarizes the contradiction between the relative simplicity of his mission and the complicating nature of his imagination with the expression, "People don't take a fine-tooth comb to groom a horse" (98). In particular, Strether's imaginative faculty affects his mission by allowing him to conceive of Madame de Vionnet as both good and bad, as both the paradigm of Parisian aesthetics and civility and also as lethal to the Newsome's familial and business interests. In short, Strether's active imagination serves to protract the act of judgment that would settle the situation because it allows him to vacillate freely between two conceptions of Madame de Vionnet, who is, like Strether's notion of Paris, "all surface one moment" and "all depth 
the next" (83). Indeed, Madame de Vionnet "spoke $[\ldots]$ as if her art were all an innocence, and then again as if her innocence were all an art" (312).

The case finally resolves itself in the famous Lambinet scene (Book XI, Chapters III and IV) when, by sheer coincidence, Strether happens upon Chad and Madame de Vionnet in the country, in which circumstance the latter two display unambiguous signs that their relationship is one of sexual intimacy. One of the effects of this chance meeting is that Strether is forced to recognize that their relationship is not wholly virtuous, and as a result has to confront the fact that he has misconceived the most basic fact of his case: the purity of Madame de Vionnet and Chad's relationship. But while Strether is hereby forced to recognize the carnal nature of this relationship, he does not, on the basis of this new information, resolve to send Chad home. Rather, the coincidental meeting prompts him to reevaluate his own modes of judgment, at which point he decides to return to Woollett on his own while holding the belief that Chad should remain in Paris. The full irony of this ending is revealed when Strether, whose mission it was to bring Chad back to Woollett, says to Chad in the penultimate chapter, "It's not a question of advising you not to go [home...] but of absolutely preventing you, if possible, from so much as thinking of it" (459). At the end of the novel, no progress has been made toward resolving the problem that Strether was originally meant to address: Chad's absence. Instead, Strether's appreciation of the situation is the thing that gets resolved, giving support to the idea that the subject of the novel is neither Chad's situation nor Strether's mission, but rather Strether's perception of these things.

This story has a circular shape. It begins with Strether embarking on the mission to repatriate Chad and moves in a direction towards this telos of repatriation. But just as 
Strether approaches this end point - that is, when he is given an opportunity to execute his objective - he wavers and temporizes. The idea of an opportunity just barely missed is dramatized in the middle chapters of the novel: in Book VI, Strether makes clear to Maria Gostrey that he has just recently decided not to take Chad back even if the latter expresses a willingness to go (228), while the following book has Chad approach Strether to finally express this willingness (248). The remaining chapters of the book (that is, up until the denouement of the Lambinet scene of Book XI) portray Strether's aforementioned vacillation, a concomitant of which is Strether's not returning home himself. Indeed, Strether not only stays on in Paris, but also toys with the idea of forming a sort of social threesome made up of himself, Chad Newsome, and Madame de Vionnet (402). At this point he is intentionally as far as possible from completing his mission; geographically, however, he is still in a position to do so. But when he happens upon Madame de Vionnet and Chad in the country, he comes to a full realization of the extent to which the pair is a strict couple, which extinguishes any possibility of the hoped-for threesome. At this point, Strether is relieved of any inclination to stay on in France, and the circular telos of a story that starts with a single objective, approaches the realization of that objective, and then settles again at the full distance from this realization is reflected in the geographical trajectory of the novel: Woollett - Liverpool - Chester London - Paris - Liverpool - Woollett. The story's circular shape is reinforced with the image that Strether uses near the end of the novel to make sense of his own experiences: "He found on the spot the image of his recent history; he was like one of the figures of the old clock at Berne. They came out, on one side, at their hour, jigged along their little course in the public eye, and went in on the other side. He too had jigged his little course 
- him too a modest retreat awaited" (467)..$^{32}$ In terms of its story, then, The Ambassadors is - like the carousel of the clock at Berne and the geographical movement of the novel's protagonist - decidedly circular.

But while the image of the figure in the clock is circular, implicit in it is the incomplete nature of the connecting segment: the dim and unmentionable "home" that the figure makes of the clock's interior. This image, which imposes a semi-circular linearity on a circular object, and which represents a trajectory that shrouds origins and destinations in mystery, can be said to represent the relationship between the novel's story and its narrative, between its fabula and its sjuzhet ${ }^{33}$ Emma Kafalenos expresses a similar idea when she argues that The Ambassadors is a novel that represents "less than one complete narrative sequence" (118). And although Kafalenos makes her argument by employing a complex set of narrative functions derived not from French or AngloAmerican narrative theory, but from the work of the Russian Formalist Vladimir Propp, given that Genette's story-narrative duality is based on the Russian Formalists' fabulasjuzhet distinction, her conclusions can be made useful for elucidating the current thesis. In her essay, Kafalenos argues that the sjuzhet of The Ambassadors is "cut off at both ends" (124). By this she means that there are narrative functions - or elementary story

${ }^{32}$ The Penguin Classics edition of The Ambassadors gives the following note about the Berne clock: "The clock on the Zeitglockenturm in the centre of Berne, Switzerland, famous for the mechanical bears that parade across its front every hour or so" (495). The clock tower is also noteworthy for indicating both time and space, given that it has served as a reference point for determining spatial relations within the canton of Berne: "The clock was not only the official time by which other clocks were set, but also the point from which distances for cantonal mileposts were measured" (Lambert 93).

${ }^{33}$ In the glossary to Phelan and Rabinowitz, the editors define these two terms in the following way. "Fabula: the sequence of a narrative's events in chronological order; more generally, the what of narrative before it is rendered in discourse" (545). "Sjuzhet: the fabula rendered in a specific narrative discourse; the synthesis of story and discourse" (550). The terms are credited to the Russian Formalists (Prince 28, 89). 
components - that occur before and after the narrative sequence represented by the text that either remain wholly absent from (that is, not represented in) the narrative, or are revealed only parsimoniously throughout the course of the narrative. An example of a narrative function that is absent at the beginning of the text, and which gets revealed only eventually, in a sort of untimely manner, is the initial impetus for Strether's trip to Europe. According to Kafalenos, every story begins in equilibrium, and the story progresses when this equilibrium is upset. Because the upsetting of the novel's equilibrium occurs in America, when Mrs. Newsome and her associates discover that Chad is under the sway of a lover - and, more importantly, before time- 0 of the represented events of the narrative - the text is severed from its own beginning. A more extreme example of this phenomenon is the complete absence of concluding elements in James's story or fabula. Indeed, “After the conversation at the novel's end between Strether and Maria Gostrey, there are no further events in the represented world, just as there are no further events in the representation. James's fabula has no concluding segment; neither events nor functions are given" (Kafalenos 133). In short, James's narrative does not tell the whole of its story, but rather a version of it that has both the beginning and ending lopped off. But while Kafalenos argues that no story elements exist beyond the concluding scene of the narrative, it is arguable that Strether's inevitable return to America is one such element. Thus geographically, the circular story that begins and ends in America gets truncated by way of the abbreviated narrative, which only represents a linear path from Chester to Paris via London. If the representation of the initiating and concluding story elements - along with the associated point of geographical origin and conclusion (that is, Woollett) - would give the narrative a 
conclusive circularity, the absence of these things at the narrative level rather gives it a linearity that stresses the distinction between beginnings and endings, origins and destinations. It is thus important that the home for the figure in the clock - the place that is both an origin and a destination - is a place of darkness and mystery.

But what of the story elements that occur before the narrative's first scene in Chester? Surely they get represented at the level of narrative, thus illuminating this originary darkness? Indeed, in the preface to the novel, James himself expounds on the means by which these aspects of the story come to surface in the narrative. James writes, "[Maria Gostrey's] function speaks at once for itself, and by the time she has dined with Strether in London and gone to a play with him her intervention as a ficelle is, I hold, expertly justified. Thanks to it we have treated scenically, and scenically alone, the whole lumpish question of Strether's 'past', which has seen us more happily on the way than anything else could have done" (15). Because Strether does not narrate his own story - and is therefore not able to back-fill information by recounting it to a narratee the originary story elements to which only he is privy have to be conveyed at the level of narrative through other means. One such means is the dialogue between Strether and the novel's ficelle, Maria Gostrey. ${ }^{34}$ In the scene that James refers to in the above passage from the preface - which takes place in Book II, Chapter I - Strether discloses for the first time, through such dialogue, the nature of his mission to Paris (59), the size of

\footnotetext{
${ }^{34}$ In A Glossary of Literary Terms, the term "ficelle" is defined as a type of confidant: "In prose fiction a famed confidant is Dr. Watson in Arthur Conan Doyle's stories about Sherlock Holmes [...]. The device is particularly useful to those modern writers who, like Henry James, have largely renounced the novelist's earlier privileges of having access to a character's state of mind and of intruding into the narrative in order to communicate such information to the reader. [...] James applied to the confidant the term ficelle, French for the string by which the puppeteer manages his puppets" (46).
} 
Chad's immediate family and this family's history (60-71), and details about his own American employment (67). So while Strether does not have an implied auditor to whom he can convey these story elements, he does have an explicit auditor in Maria Gostrey; and in scenes such as the one set in the London theatre, Strether can be said to illuminate the interior of the home from which he has begun to "jig," thus shedding light on the obfuscated segment of the story's circle.

But this is a sort of disingenuous exposition. Rather than being expository, the scene at the theatre sheds only partial light on details that remain by and large mysterious. That is, while Strether is able to converse with Maria Gostrey on all sorts of topics as if she were an old confidant, he also withholds from her much important information about his past life as if he were being interrogated by "the very deuce" (68). In such instances, Gostrey attempts to get "everything out" while Strether "puts everything in" (71). There are two particular pieces of information that he withholds from her, the dissimulation of this information exhibiting the rationale by which (and the extent to which) the originary story elements remain concealed from the level of narrative. The first piece of information is the identity of the famous product of the Newsome's manufactory. When in conversation about this manufactory, Strether refuses to name its product, dismissing this thing as a "small, trivial, rather ridiculous object of the commonest domestic use" that is wanting in "dignity" (63)..$^{35}$ One reason for his silence on the topic is his feeling that the thing is out of keeping with the beauty and civility of the place in which they are conversing, the London theatre: "Right here therefore, with everything about us so grand

\footnotetext{
${ }^{35}$ In the introduction to the Penguin Classics edition of the novel, Adrian Poole writes, "James teases his readers by never naming it, though this has not stopped their speculating about alarm-clocks, button-hooks and chamber pots" (xvii). In the text, Maria Gostrey's suppositions include clothespins, saleratus, and shoe-polish (63).
} 
- [...]. It's vulgar" (63). Strether and Maria's discourse is thus muted by Strether's sense of civility. And while the unidentified product is figured here as trivial, later on in the novel - that is, in the final chapter - it is rather figured by Strether as bearing a great power to signify: "He offered now, should she really like to know, to name the great product of Woollett. It would be a great commentary on everything" (467). But the product remains unnamed, as Maria declines his offer, possibly from a sense of propriety. Whether or not the object would have had the power to illuminate much of the antecedent elements of the story, the sustained non-articulation of its identity exhibits the extent to which Maria Gostrey, as a ficelle, fails to illuminate what Emma Kafalenos refers to as the story's preliminary details.

The second piece of information that is integral to the illumination of the originary story elements, and which Maria fails to bring out at the level of narrative, is the nature of Strether's relationship to Mrs. Newsome. The degree to which this detail threatens to surface, along with the mystery in which it remains shrouded throughout the narrative, is dramatized in the scenic chapter at the London theatre. Throughout this chapter, Maria repeatedly poses to Strether questions that are intended to illuminate the nature of this relationship, while Strether responds to Maria's questions by repeatedly dissimulating this information. When Maria asks Strether whether Mrs. Newsome is attractive - a question that is posed in order to make Strether betray his valuation of his fiancée - he is taken aback, and then responds in a qualified way, being careful not to be too affirmative or too negative: "Mrs. Newsome, I think, is handsome, though she's not of course, with a son of twenty-eight and a daughter of thirty, in her very first youth" (60). Likewise, after Maria follows this question with one that is meant to make Strether 
express an unambiguous opinion, Strether rather maintains his ambivalence: "“And is she wonderful,' Miss Gostrey asked, 'for her age?' / Strether seemed to feel with a certain disquiet the pressure of it. 'I don't say she's wonderful. Or rather,' he went on the next moment, "I do say it"' (60). This game of cat and mouse continues until the end of the scene, at which point Maria is entering the carriage that will take her home, and puts to Strether, point blank, the question, "What - by failure [of his mission to procure Chad] do you stand to lose?" (73). According to the trajectory of the previous dialogue, she means by this, "What would you lose if you were to lose Mrs. Newsome?" or, "How much does she mean to you?". Strether responds to this query with a precipitous "Nothing!"' (73). However, when Maria repeats the same question within a few moments, Strether reverses his opinion by promptly saying, "Everything" (73). Thus a scene that was supposed to clear up the whole question of the ambiguous past ends on a note of ambiguity with respect to one of the most pertinent aspects of Strether's life at home: his relationship to the woman on whose behalf he is acting as ambassador. This ambiguity continues to hover over the narrative right up until its concluding chapters. James's remark in the preface that Maria Gostrey extracts from Strether, and brings out on display at the level of narrative, "the whole 'Iumpish' question of Strether's past," is iterated with an ironic accent in Book XI. When Strether tries to convey to Maria, in overly ambiguous and abstract terms, that a concomitant of Sarah Pocock's recent presence in Europe has been the virtual presence, too, of Mrs. Newsome - or, as Strether calls her, a "whole moral and intellectual being or block" (405) - Maria responds with the comment, "Fancy having to take at the point of the bayonet a whole moral and intellectual being or block!" (405). This passage dramatizes James's own irony when he 
refers to the anterior facts of the narrative that get disclosed on the level of narrative as the "lumpish" past. Accordingly, the anterior story elements are made present at the level of narrative in a muted form: in the form of an abstract (and yet immanent) absence.

Tzvetan Todorov identifies the concept of immanent absence as the most common element in all of James's fiction, or "the figure in the carpet" of James's oeuvre. Todorov writes, "Thus the secret of Jamesian narrative is precisely the existence of an existential secret, of something not named, of an absent and superpowerful force which sets the whole present machinery of the narrative in motion" (145). He goes on to write, "The absence of the cause or of the truth is present in the text - indeed it is the text's logical origin or reason for being. The cause is what, by its absence, brings the text into being. The essential is absent, the absent is essential" (145). In The Ambassadors, this essential (or immanent) absence is Mrs. Newsome - or, more specifically, the nature of Strether's relationship to this character. And the failure of Maria Gostrey - whom James identifies ironically as an effective ficelle - to extract this secret from Strether reflects its power to remain unstated. Gostrey expresses the sustained ambiguity of this detail when she says to Strether in one of the concluding chapters of the novel, "I never quite knew where you were. There were moments $[\ldots]$ when you were grandly cynical; there were others when you were grandly vague" (451). Chad makes a similar statement in the episode that follows this one: "I don't know what you've really thought all along; I never did know for anything, with you, seemed possible" (458). The immanent absence of this detail is also represented figuratively at the level of narrative with the muted presence of Strether's epistolary correspondence with Mrs. Newsome, which represents, moreover, Strether's connection to a time and place antecedent to the narrative. While these letters 
are repeatedly referred to at the level of narrative ${ }^{36}$ their contents are never disclosed.

The story's past is thus perpetually present, and thereby functions as an integral narrative element. However, as a qualification of its persistent presence, this story content retains a degree of secrecy, a threshold level of absence.

The importance of the immanent absence lies not only in its stubborn persistence as a negation, but also in its ability to set the "machinery of the narrative in motion" (Todorov 145). In The Ambassadors, it is not the existence of an antecedent function that propels the narrative forward, but rather the immanent absence of this function. Accordingly, a gaping, omni-present hole in Strether's past produces a vacuum in his future into which the narrative is drawn. On the one hand, if it were made clear that Strether values his relationship to Mrs. Newsome and would thus not wish to jeopardize it by failing in his mission, the concluding function of the story would doubtless be the successful or unsuccessful completion of his mission - that is, on Mrs. Newsome's behalf, as her ambassador. ${ }^{37}$ But this inevitable conclusion would threaten to trump the importance of the intervening narrative sequence, as it would loom too large throughout the narrative as an eventuality. On the other hand, if it were made known at the level of narrative that Strether does not value his relationship to Mrs. Newsome, the drama associated with the uncertain completion of his mission would be small, as nothing - that is, granting that Strether does not value any form of monetary recompense - would hinge on its successful completion. In this case, the narrative would lack a foreseeable end, and would thus progress in an unstructured fashion. But the sustained ambiguity of Strether's

\footnotetext{
${ }^{36}$ See James, The Ambassadors 75, 136, 246, 261-62, 332.

${ }^{37}$ By not presaging a conclusion, James can be said to preempt the inclination on the part of the reader to polish off the text as if he or she were swallowing a "pudding" (James, "Art" 855).
} 
feelings for Mrs. Newsome means that the narrative is able to progress freely towards a concluding function that is by no means foregone. Ultimately, not knowing how Strether feels about Mrs. Newsome implies not being able to anticipate how Strether will act: past ambiguities promote subsequent ambiguities, and all that is left is the in-between. Thus, the persistence of the immanent absence maintains a distinction between the bracketing story elements that are marked by absence and the intervening narrative that is, in contradistinction, identified with the characteristic of presence. It also propels the narrative forward, giving it a unilinear momentum. Accordingly, the interior of the clock tower - which represents the connecting segment of the story circle - is a distinct reality, but one that is never fully elucidated in order to protect the relative importance and linearity of the figure's exterior course.

To summarize the relationship between story and narrative in The Ambassadors: The story elements that are anterior and posterior to the frame of the narrative get represented at the level of narrative, although in a mediated way that maintains the distinctness of the two levels and emphasizes the spatio-temporal (or geo-temporal) linearity of the narrative sequence - as opposed to the circularity of the story sequence. The narrative is generally identified with the quality of presence, represented by the presence, throughout the narrative, of Strether, who is the lone focalizing character of the fixed-focalized narrative. On the other hand, the story is marked by absence and lifelessness, which is exemplified by the character of Mrs. Newsome, whose presence on the level of narrative is a form of absence, maintaining as she does an abstract and lifeless lumpishness from beginning to end. In short, the relationship between the narrative and story is manipulated in a way that emphasizes the linearity of the former, thereby paving 
a unilinear geo-temporal (or spatio-temporal) path on which the protagonist may travelone that is akin to the carousel on which the figure in the Berne clock travels. Turning to the relationship between narrative and the narrating instance, is it not, then, also the function of the text's narrator to maintain an attenuated presence so that the narrative may exist in the fullest sense possible? In other words, is the relationship between narrative and story not analogous to the one between narrative and narrating instance? For example, an omniscient narrator would be inclined to explicate, or back-fill, the anterior story elements and thereby disclose the Jamesian secret. Is the narrator's renunciation of this office not evidence that his primary function is to subordinate himself to the narrative - in this sense denying himself a prominent place in the text so that he does not detract attention from the narrative per se? This is certainly the phenomenon that Percy Lubbock refers to when he writes that the author of The Ambassadors "withdraw[s]" from the text to "let Strether's thought tell its own story" (156)? And even though Genette corrects Lubbock, arguing that there is no such thing as a narrator-less narrative, as we have already seen, Genette's description of the deixis of heterodiegetic narration promotes an image of a Jamesian narrator that possesses scant subjective characteristics. For example, Genette writes, "The chief temporal determination of the narrating instance is obviously its position relative to the story" (216). But as it has been previously shown, the use of subsequent heterodiegetic narration - regardless of the fact that it indicates the narrator's temporal relation to the story - can be said to imply subjective absence as compared to the technique of subsequent homodiegetic narration, which identifies the subjective features of the narrator not only through their temporal relation to the story, but also by cross-referencing the characteristics of the narrator with those of the narrator's 
representative in the story. Subjectively, the heterodiegetic narrator is able to take the form of the disinterested artist whose role is to take on a reduced role: to be identified as existing subsequent to the narrative, yes, but existing in an abstract form, as the subsequent equivalent of the lumpishly anterior Mrs. Newsome. According to this analysis, the narrator is an abstract entity whose presence is an immanent absence meant to emphasize the heightened presence of the narrative text.

However, by acknowledging the conclusions that were drawn in the course of positioning James within Bourdieu's literary field, an alternative way of figuring the relationship between the narrative and the narrating instance of The Ambassadors presents itself. This alternative involves conceiving of narrative voice as an attenuated textual presence, and not as an immanent absence..$^{38}$ In his essay "Hearing Voices in Narrative Texts," Richard Aczel attempts to describe the narratological economy of The Ambassadors in such a way:

My discussion of [examples from The Ambassadors] attempts to activate the qualitative concept of voice to which this paper appeals, identifying in James an overt and distinctly audible narratorial agency on the basis of rhetorical strategy and stylistic expressivity, rather than solely according to the more widely adduced narratological principles of explicit (grammatical) self-reference, direct reader address, comment, and interpretation. (468)

In short, Aczel forgoes the use of Genette's spatio-temporal paradigm when describing narrative voice, arguing that in the absence of textual evidence evoking narratorial

${ }^{38}$ This is a subtle distinction, but it is meant to represent the difference between an author who composes in strict accordance with the autonomous principle (immanent absence) and an author who attempts to satisfy both principles when composing (attenuated presence). 
omniscience, there are not only indicators of spatio-temporal relation between narrator and narrative, but, more importantly, stylistic markers that illuminate this narrator's subjectivity. Aczel summarizes his own contribution to theories of voice by writing, "for Genette, the question of 'who' incorporates the further questions 'when' and 'from where.' [...But] the question of who can often be (although in principle doesn't have to be) predicated on the question of how" (468). He goes on to state, "a concept of voice that is inherently deaf to qualitative factors such as tone and idiom will be doing little to justify its name" (468). In reference to James's The Ambassadors, Aczel argues that James's narrator is not "covert" or relatively absent, but often "roars with lionish pride at its own dexterity" (471). According to Aczel, if the intention of James's narrator is to refuse the privilege of overt self-reference and thereby serve as a handmaiden to the narrative, the points in the text at which the narrator cannot help but express explicit pride in - and thereby draw attention to - his own linguistic facility undermine this intention. In this respect, Aczel's conception of the text's narrating voice corresponds with the one that is being elucidated in the current thesis: both conceptions figure voice in terms of presence, and both figure it as not strictly subordinated to the narrative.

But whereas Aczel's depiction of the text's narrating instance corresponds with some of the conclusions drawn thus far in this thesis - that is, that the vocal component is a textual presence and not a relative absence - it also conflicts with observations made in the two previous chapters. It was recognized in the first chapter that the Sutherland letter implores the reader to pay attention to a sustained presence - one that takes the image of the thread stretched from text's beginning to end. It was then determined in the second chapter that this thread represents the vocal trace running through the text - one that 
signals James's ability to sustain his attention over a long duration. Conversely, Aczel's image of narrative voice is one of inconsistent breaks and disjuncture; for Aczel, the narrator makes himself present in the text with occasional "lionish roars" (471) or, in other words, with ruptures in the text's temporal integrity. In order to expand on the conclusions already reached in the current thesis, narratorial prominence must rather be figured, henceforth, in terms of temporal consistency. It was also recognized in the first chapter that Genette rearticulates the conclusions of the Anglo-American Jamesians when he represents James's contribution to the theory of narrative as merely toward the concept of narrative mood. It is curious that in an attempt to amend Genette's concept of narrative voice, Aczel inadvertently emulates Genette by perpetuating this same misapprehension. Aczel writes, "Not only [...] does stylistic expressivity - style anchored in subjectivity - have an important role to play in the identification of narratorial audibility, but it must play the central role in the characterization of a narrator's voice" (472, emphasis in the original). In arguing that stylistic indicators must be the primary determiners of narrative voice, Aczel disconnects the narrator from the narrative, figuring this subject's primary identifying features as stylistic rather than narratological. Conceding to Genette's implicit idea that the Jamesian text is only exemplary - in narrato-theoretical terms - of the concept of narrative mood, Aczel prefers to adopt a stylistic paradigm in order to represent the text's narrating instance. On the other hand, the current thesis is committed to elucidating narrative voice by applying Genette's narratological theory to the fullest extent possible, only amending its blind spots through recourse to Bourdieu's sociology. That is, whereas Aczel argues that an analysis of the text's voice must forego asking the standard Genettean questions of 
"when" and "from where" to focus on the "how" of the narrating instance (468), the current thesis is committed to elucidating the narrating instance using Genette's spatiotemporal terms primarily, but also choosing and explicating these terms in a way that describes a text situated within the context suggested by the late-nineteenth-century British literary field and scientific discourses on attention. Toward this end, the spatiotemporal implications of the relationship between the narrative and the narrating instance will now be analyzed.

Just as the relationship between the story and the narrative is mediated in a way that distinguishes the geo-temporal linearity of the former from the circularity of the latter, so, too, is the relationship between the focalizing character and the narrator structured in a way that allows the latter to maintain a spatio-temporal existence that is more strictly linear than that of its textual counterpart. And while the former relationship is constructed in accordance with the literary field's autonomous principle (given that it creates an authorless organic whole), the latter relationship accords with the heteronomous principle, given that it creates a narrato-authorial subject who attains a bourgeois virtue. Regarding the latter relationship, the textual dynamic between the focalizer and narrator functions as a way of representing analepsis - narrative sequences that threaten the unilinearity of the narrative by requiring a backward, or regressive, 
movement ${ }^{39}$ - in a forward-going manner. In order to illustrate this dynamic, two scenes that include analeptic sequences will be analyzed: the scene in the London theatre (Book II, Chapter I) and the scene in the Luxembourg Gardens (Book II, Chapter II). Beginning with the scene in the theatre - in which Strether and Maria Gostrey converse about Strether's life at home - it is important to note the particular technique by which analeptic passages are prefaced in order to ensure that they are subordinated to "first narrative, ${ }^{40}$ and thus figured as progressive. This technique is best exemplified in the following quotation:

[Strether] felt as if the play itself penetrated him with the naked elbow of his neighbour, a great stripped handsome red-haired lady who conversed with a gentleman on her other side in stray disyllables which had for his ear, in the oddest way in the world, so much sound that he wondered they hadn't more sense, and he recognized by the same law, beyond the footlights, what he was pleased to take for the very flush of English life. (58)

While the scene continues on to deal with analeptic narrative content - thus taking a temporal move back in time - the above passage situates the mode by which this

${ }^{39}$ In the following, Genette defines the concept of narrative anachrony (that is, analepsis and prolepsis): "to avoid the psychological connotations of such terms as 'anticipation' or 'retrospection,' which automatically evoke subjective phenomena, we will eliminate these terms most of the time in favor of two others that are more neutral, designating as prolepsis any narrative maneuver that consists of narrating or evoking in advance of an event that will take place later, designating analepsis any evocation after the fact of an event that took place earlier than the point in the story where we are at any given moment, and reserving the general term anachrony to designate all forms of discordance between the two temporal orders of story and narrative" (Narrative 40).

${ }^{40}$ Genette defines "first narrative" in the following: "Every anachrony constitutes, with respect to the narrative into which it is inserted - onto which it is grafted - a narrative that is temporally second [...]. We will henceforth call the temporal level of narrative with respect to which anachrony is defined as such, 'first narrative"' (Narrative 48). 
sequence of analepsis is conveyed (simply, Strether) in a specific time and place, and thereby prevents backward movement by anchoring the scene in this specific place-time. In other words, the passage situates Strether's body in the scenic present: he feels very sharply the penetration of his neighbour's elbow, he sees very vividly the bright colour of her hair, and he hears quite audibly the words of his conversing neighbours. That he does not understand these words is evidence that they are not meant to signify as linguistic signs, but are rather unintelligible sounds that identify Strether's as a sensorial body situated in a particular situation. And that the two things - the play and the neighbour's elbow - blend to produce a single sensorial effect is further evidence that they are meant to represent not discrete impressions, but the whirr of sensorial data bombarding Strether's sensing body. At a later point in the scene, the technique that situates the protagonist's body in a distinct place and time in order to avoid the retrogressive movement of analepsis is reduplicated in the mode by which the aforementioned analeptic content gets represented. Because the analeptic sequence is conveyed in the form of a forward-moving conversation - that is, because it gets revealed at the level of narrative by way of a conversation between two characters - Strether's backward thoughts attain a forward character as they take the form of a progressive, embodied, interlocutionary discourse. Indeed, the things that Strether and Maria speak about follow a meandering course of spatio-temporal reference through various past places and times; but the mode by which the two interlocutors express these things follows the unilinear course of bodies in talk (that is, so many words per second along a unilinear axis). And by definitely situating Strether's sensorial body within the scene, the author ensures that these two characters are appreciated as such. Thus, if the narrative is 
unilinear, it is because Strether's body is distinctly situated along the numerous points of the geo-temporal path in order that the narrative does not take a backwards step. And to maintain the linear flow of the enunciated narrative, the narrator simply has to follow (or provide the play-by-play of) this subject as he makes his way along his unilinear geotemporal path.

But while James writes that this scene completely deals with, and thereby disposes of, the question of Strether's past, it is significant that the chapter that follows it returns to the subject of the past, disclosing details about Strether's deceased wife and child without the aid of a ficelle. In this scene, Strether is settled in the Luxembourg Gardens, where he has come to read his recently received letters from Woollett. As it was previously mentioned, the content of these letters is never explicitly represented at the level of narrative; in this instance, it is suggested that the letters inspire in Strether an act of reverie - a roving and rambling remembrance of things past. Ironically, by representing the woman on whose behalf Strether has come to Paris to conduct "business" - thereby inciting in Strether a drive to make progress in the direction of this business - the letters remind Strether of all the ways in which he has not made progress (in the sense of making efficient use of one's time toward a singular goal) in the past: "Everything he wanted was comprised moreover in a single boon - the common unattainable art of taking things as they came. He appeared to himself to have given his best years to an active appreciation of the way they didn't come; but perhaps - as they would seemingly here be things quite other - this long ache might at last drop to rest" (79). As a result of the connection drawn between his well-intentioned future and his profligate past, Strether's thoughts move to this past, and jump from a reflection on the 
death of his wife (79), to the subsequent death of his son (79), to the still more recent evening at the London theatre with Maria Gostrey (80), back to the time of his first trip to Paris with his wife (80-81), and then ahead to reflections on Chad's initial tour through Europe and settlement in Paris (82-83). These reflections thus take the shape of the image described in the same chapter: "It had not been, so much achievement missed, a light yoke nor a short road. It was at present as if the backward picture had hung there, the long crooked course, grey in the shadow of his solitude" (79). By acknowledging that reverie is a condition in which the individual "rambl[es] in thought, following everything in turn, but nothing long" (Spiller 501), Strether's thoughts in this scene can be said to accord with the crooked road - the very picture - of reverie. Like the content of Strether and Maria's conversation, it meanders through various past place-times; in short, it signifies the antithesis of unilinear sustained voluntary attention.

But before the onset of, and in preparation for, this sequence of meandering and backsliding analeptic narrative - that is, to buttress the narrative against this type of movement by firmly situating Strether's body in the narrative present - this body is described in relation to the vividly sensorial objects of its surroundings:

In the garden of the Tuileries he had lingered, in two or three spots, to look; it was as if the wonderful Paris spring had stayed him as he roamed. The prompt Paris morning struck its cheerful notes - in a soft breeze and a sprinkled smell, in a light flit, over the garden-floor, of bareheaded girls with the buckled strap of oblong boxes, in the type of ancient thrifty persons basking betimes where terrace walls were warm, in the blue-frocked brass-labelled officialism of humble rakers and scrapers, in the deep references of a straight-pacing priest or the sharp ones of 
a white-gaitered red-legged soldier. He watched little brisk figures, figures whose movement was as the tick of the great Paris clock [...]. (76) ${ }^{41}$

Here, once again, as in the scene in the theatre, Strether's body is geo-temporally placed in preparation for a bout of analepsis. The colours of the Parisians' frocks, pants and gaiters are - like the words of Strether's neighbours at the theatre - non-descript, being merely blue, white and red. Thus these aspects of the garden can be said to exist at the level of narrative not as a form of realistic detail, but as a means of representing Strether as a sensorial presence. The Parisian clock that ticks to the movement of these figures represents the linearity of narrative space and time, and signals that the narrative clock is still moving forward at its regular pace throughout the ensuing analepsis. Furthermore, the chapter as a whole replicates the geo-temporal linearity of the narrative, as Strether is said to move from his banker's (which is referred to as the European "abutment of some transatlantic bridge" (75)), to the garden of the Tuileries (76), then to the Luxembourg Gardens (77) and on to Chad's residence in the Boulevard Malesherbes (88). Thus, by narrating this sequence of analepsis not as the enunciated thoughts of Strether but as the various cognitive and neurological movements of a body in thought - a sensorial body moving in time and space according to a linear spatio-temporal trajectory - the narrator is able to narrate along this same trajectory, thus maintaining the spatio-temporal linearity

\footnotetext{
${ }^{41}$ It will be noted by the attentive reader of James that preparation for the analeptic passage actually occurs in a setting distinct from the one in which the analeptic reverie takes place, that the former occurs in the Tuileries garden, while the latter occurs in the Luxembourg Gardens - which is on the other side of the Seine and some two kilometres from the Tuileries. Nonetheless, the fact that James almost completely elides Strether's walk from one to the other, only representing it by a single sentence (76-7), serves as evidence that the two settings are supposed to be conflated to a certain degree, and that the situating of Strether's physio-sensorial body in the Tuileries garden is meant to prepare Strether for his reveries in the Luxembourg Gardens.
} 
of his discourse. Strether is thus like the figure in the clock at Berne, which moves along a linear spatio-temporal track; and the clock that continuously ticks in the background of this particular scene is analogous to the relentless ticking of the immemorial Swiss clock.

This scene represents one of the most sustained analepses of the narrative; it is also the most sizeable one (in terms of narrative duration) not conveyed through the interlocutionary medium of Maria Gostrey. As such, it represents one of the most significant deviations in the general mode that maintains the linearity of the narrative through the absence, or strict control, of antecedent details. Furthermore, because these analepses are a product of Strether's meandering attention, this passage marks a point at which the protagonist's thoughts move in a direction opposed to that of the advancing narrative. However, as Strether's thinking body - which exists according to a sort of linear biological time - mediates the narrator's relationship to the narrative, this scene does not constitute a deviation in the narrator's forward progress. Rather, the narrator takes a position in relation to Strether similar to the one between the clinical scientist and the embodied subject of clinical experimentation. This dynamic is implied in the following by Gustav Spiller: "Viewing the subject of attention from a still higher position (which embraces the physiological aspect), we say that in the normal waking state something is always immediately given and that that something is a constant quality which constantly changes at a constant rate" (523, emphasis in the original). Here, Spiller can be said to describe the relationship between the narrator and protagonist during the scene in the Luxembourg Gardens. Because the narrator narrates in this instance not Strether's subjective thoughts, but rather describes, in a clinical manner, the constantly advancing movements of a body in thought, the narrator is spared the counter- 
linear implications of tracing a sequence of reverie, which mimics the "waves, which form the [turbulent] ocean of thought" and represents "the several subjects which constitute the field of attention in time" (Spiller 511). In relation to the narrator, Strether is a scientific subject of clinical inquiry; and thus the narrator is afforded the luxury which is not afforded the focalizing subject - of attending to an object that maintains a strict spatio-temporal linearity. The narrating instance, which is a relationship between the narrator and focalizer that is patterned on the relationship between clinician and clinical subject, is thus manipulated in a way that constructs a virtuous act of sustained voluntary attention.

In conclusion, Strether's perceiving and cogitating body exists as the narrator's subject of narration. As a result, the narrator is allowed to perform the narrating act according to the geo-temporal linearity represented by this body's instantiation on the level of narrative, moving as it does from Chester to Paris via London. This linear movement is also represented by the semi-circular linearity in the figure of the clock at Berne. And while analepses do get represented at the level of narrative, they are strategically controlled in order to maintain the unilinearity of the narrating subject. For example, in the scene at the London theatre, analepses are represented in the form of dialogue, and the forward movement of embodied interlocution - that is, of bodies discoursing through time - provides the unilinear structure for a passage that deals with the temporal vagaries of retrospection. But when Strether conducts an act of retrospection on his own (that is, without the aid of the ficelle), with his own thoughts moving backward in time, pains are taken to frame this subject as a perceiving and cogitating body within the narrative present, after which the narrator is able to narrate not 
Strether's retrospective thoughts, but rather the movements of a body in thought, the latter more strictly abiding by the unilinearity of time's arrow. In this sense, the narrating instance has a greater temporal consistency than does the focalized narrative that portrays Strether's consciousness as if it were on a stage. Rather than serving the narrative, the narrating instance is served by it, as it identifies the peak or purest aspect of the text's spatio-temporal unilinearity. And the Bourdieuian principles of composition can be said to interact, since the autonomous textual element helps produce a narrato-authorial discourse that signals the bourgeois virtue of sustained voluntary attention, and thus marks the text's compliance with a heteronomous principle of construction. The fourth and final chapter will identify the linguistic traces left by this attending author. In narratological terms, this chapter will analyze, more directly, the textual instantiation of the vocal half of the mood-voice duality. In Bourdieuian terms, it will primarily focus on the heteronomous aspect of Jamesian narrative. And according to the psychological paradigm, it will delineate the textual manifestation of the attending clinician. 
Chapter 4: Saving the Present; or, Voice Per Se

Not till, on the purple divan before the perfunctory bock, he had brought out the words themselves, was he sure, for that matter, that the present would be saved. (James, The Ambassadors 122)

The previous chapter used Genette's narratological paradigm to characterize the narrator of The Ambassadors as a textual subjectivity that gets constructed by way of its relationship to the narrative, after which it drew on Bourdieu's concept of the heteronomous principle in order to stress the narrator's heightened importance within this textual economy. This was done in an attempt to correct the general narratological bias exhibited even by supposed revisionists such as Gérard Genette - toward analyses of narrative mood in James while ignoring voice in the same. It was also done to reflect James's existence as a literary agent situated within the British literary field of the earlytwentieth century: one who expressed dueling heteronomous and autonomous dispositions by setting up an inter-subjective textual dynamic that is a homologue of the relational, bi-subjective experimental dynamic on exhibit in late-nineteenth-century psychological discourse. Building upon the analyses of the first three chapters, the current chapter will proceed to analyze the text's narrative voice per se by looking at the linguistic indices of a narratorial subjectivity that stands in for James's heteronomous self-ascription of the bourgeois virtue of sustained voluntary attention. And while this chapter will move beyond the relational analysis conducted in the previous chapter in order to look at narrative voice more exclusively, it will nonetheless be conducted in 
explicitly relational terms. That is, the narrating instance will be read in relation to its non-existent other: the periods in the narrative of ellipsis, or "non-narration," such as chapter breaks. It should be clear by now that the narrato-authorial subject inscribed in The Ambassadors follows a unilinear spatio-temporal course through the text. This idea will be reinforced in the current chapter through an identification of the linguistic indicators of this sequence. The unambiguous nature of these indices will be demonstrated by linking them firmly to instances in The Ambassadors of the pluperfect verb tense. Finally, this chapter will close by addressing a topic not yet discussed, but one that poses a particular challenge to the validity of the current thesis: narrative prolepsis. It will do so by focusing on the oft-analyzed Lambinet scene, figuring this scene as one detached from the first narrative, and thus as an exception to the rule of the thread's continuity - or as the lone flaw in James's Persian carpet. It will conclude by arguing that the proleptic mode gets employed in the Lambinet scene in order to reconnect a detached sequence of ekphrastic narrative to the verisimilar, unilinear narrative; in other words, it will be claimed that this mode is employed in order to repair the narrato-authorial subject's damaged virtue. But before analyzing prolepsis, the stylistic features of the text that repeatedly locate the narrating subject along the geo-temporal (and thus the spatio-temporal) narrative arc will be elucidated.

A large portion of the previous chapter was dedicated to figuring the relationship between narrative and story as the mode by which external analepses get represented in a way that preserves the narrative present. To analyze narrative voice per se, the current chapter will look at the relationships between narration and non-narration - that is, between explicit and elided narrative - to demonstrate how this relationship is mediated 
through the narration of internal analepses. ${ }^{42}$ Toward this end, it will pay to examine James's comments on the serialization of The Ambassadors, specifically those comments that refer to the narratival effects of the novel's serial publication. In the following passage from the New York Edition preface to The Ambassadors, James credits the serial format for encouraging an episodic mode of representation:

"The Ambassadors" had been, all conveniently, "arranged for"; its first appearance was from month to month, in the North American Review during 1903, and I had been open from far back to any pleasant provocation for ingenuity that might reside in one's actively adopting - so as to make it, in its way, a small compositional law - recurrent breaks and resumptions. I had made up my mind here regularly to exploit and enjoy these often rather rude jolts - having found, as I believed, an admirable way to it $[\ldots]$. (10, emphasis added)

By promoting a month-to-month structure, the periodical format encouraged James to divide the text into segments; it is therefore no coincidence that the novel is made up of twelve uniformly sized books. ${ }^{43}$ And not only did this format promote the uniformity of book size; it is also conceivable that it regulated the form taken by each of the book's chapters, given that chapter composition becomes, in the writing of a serial text, a matter of dividing up a whole rather than making additions of unmitigated extent. But as the

\footnotetext{
${ }^{42}$ Genette distinguishes between internal and external analepses in the following: "We can thus describe as external [an] analepsis whose entire extent remains external to the extent of the first narrative. [...] Inversely, we will describe as internal analepsis the sixth chapter of Madame Bovary, dealing with Emma's years in the convent, which are obviously later than Charles's entrance at school, which is the novel's starting point" (Narrative 49).

${ }^{43}$ Matthiessen writes, "James had always been uneasy - as well he might have been! with his age's demand for serialized fiction. But here for once he felt a great stimulus to his ingenuity, and he laid out his novel organically in twelve books, each of which could serve for a month's installment" (19).
} 
above quotation represents the scope of James's remarks in this preface on the narrative effects of the serial format, the specific nature of these effects is left open to conjecture. For example, the suggestive brevity of these comments prompts the following question: What was the author's "admirable way" to "exploiting and enjoying these often rather rude jolts"? One plausible answer follows from the conclusions of the previous chapter. It may be hypothesized that because the serial format encouraged a segmented narrative, it encouraged, at the same time, a narrative structure made up of a series of scenic segments. As such, it encouraged narrative unilinearity by promoting a mode that was able to represent the unilinear passage of time through the representation of bodies discoursing along a linear spatio-temporal axis. Thus, when James writes that he "had made up his mind" to "exploit" the "recurrent breaks and resumptions" of serial publication, he conceivably means here that he used the natural borders that frame serials and chapters as a way of framing his scenes. And as the scenic mode promotes spatiotemporal unilinearity, by encouraging the scenic mode, the serial format promoted such linearity as a concomitant. Thus it may be suggested that James used the divisions imposed by serialization to bracket his scenic episodes at the level of book and chapter, with this structure promoting a narrative form that has a predominantly forward thrust.

But how do these abrupt episodic endings aid the author in constructing scenes, apart from simply providing a convenient frame for them? A possible answer to this question is that the serial format, which provides a structure that offers natural breaks between episodes, also divides and delineates the text's production labour. While the scenic mode permits the representation of analepses as forward motion, it also brings the temporal flow of narrative to a violent halt with its "rude jolts," or the periodic and 
unrealistic lowering of its curtain. The break also marks a gap in the overall spatiotemporal linearity of the narrative, as the scene that follows the break usually resumes at a spatio-temporal distance from the previous one. It is thus a fortuitous feature of the serial text that these anti-linear features of the narrative can be attributed to an extraauthorial agent: the anonymous individual responsible for the conventions of serial publication. Such a distribution of labour reflects Genette's distinction between the official and the officious ("Paratext" 267)..$^{44}$ The official aspects of the text are the ones for which the author takes credit; conversely, the officious features are those ascribed to an agent other than the author. In the case of James's serialized novel, one of its official (or heteronomous) features is the temporal-linearity that the episodic structure encourages, while the concomitant officious aspect is the break and gap in the time sequence that come with the end of each serial and chapter. Thus if James had written an unserialized novel, he would have been responsible for both the temporally linear and atemporal aspects of its structure; but because the breaks are attributable to the nonauthorial entity who is responsible for the conventions of the serial format, James is able to take credit for the temporal gains of the scenic structure, all the while displacing onto this entity the temporal losses.

But while the scenic structure encourages a type of temporal linearity that is attributable to the text's author, it has an obverse that poses a threat to such linearity: narrative summary. Genette describes the relationship between these two contrasting, but closely related, features of narrative discourse in his chapter on duration: "The real

\footnotetext{
${ }^{44}$ While Genette claims that paratextual material may be interstitial, or within the pages of the text - examples of which are chapter titles and foot-notes ("Paratext" 263) - what we are dealing with here, in the case of chapter breaks, is a sort of negative interstitial paratext, or interstitial paratext not as a supplementary feature but as the absence of text.
} 
rhythm of the novelistic canon [...] is thus the alternation of nondramatic summaries, functioning as waiting room and liaison, with dramatic scenes whose role in the action is decisive" (Narrative 109-10). If the relation of narrative to story can be imagined as a series of scenic snapshots stretched out across - but only partially representing - the story sequence, narrative summary is one of the techniques that most efficiently fills in the interstitial spaces, and thereby provides spatio-temporal linkages between scenes. And as chapters in The Ambassadors often end in concurrence with the end of a scene, the chapter breaks serve to stand in for this elided story content or interstitial space, meaning that summaries usually occur at chapter openings. At the opening of such chapters, then, the narrator must jump back in both space and time to bring to the level of narrative the elided story content, thereby disrupting the spatio-temporal linearity of the narrative. In a sense, this system of repetitive alternation operates on the basis of an exchange economy: for any linear-temporal gains made through the representation of a scene, payment has to be made in the form of summary. The narrative is thus made to jump back and forth without gaining consistent forward momentum. And while James refers to the episodic demands of the periodical form as features that allow him to collect the economic windfall of the scenic structure - that is, as a convention that he is able to "exploit" (The Ambassadors 10) by officially accruing its temporal credits while officiously displacing its debits - he is not absolved of making the payments demanded by summary. This is especially true in the context of the current thesis, given that this work has consistently identified the text's author with the narrating voice - the subjectivity primarily responsible for narrative summary. Thus, an official representative is made to pay at the opening of the novel's chapters, with an amount of his heteronomous stockpile, for any 
temporal gains made by way of a scenic episode (notwithstanding the officiousness of the imposed chapter breaks).

This effect is reflected in the results of a quantitative analysis of the text. ${ }^{45}$ Of the thirty-six chapters that make up The Ambassadors, twenty-eight (or 78\%) begin with an instance of diegesis - a passage of narrative strictly conveyed in the narrator's voice, and one often indicating narrative summary. The remaining $22 \%$ begin with a passage of scenic narrative predominantly composed of character dialogue. Conversely, twentyseven (or $75 \%$ ) of the thirty-six chapters end in a scenic manner, while only $25 \%$ end with diegetic narrative. Of the thirty-five chapter breaks, twenty-two (or 63\%) mark a point of alternation from one mode of narration to the other, while twenty of the twentytwo alternating breaks (or 91\%) involve a shift from the scenic to the diegetic mode. Overall, then: the majority of chapters begin in the diegetic mode, while a similarly predominant number end in the scenic one; and the novel's chapter breaks mark a point of alternation between the scenic and diegetic mode, with the vast majority of these shifts moving from the scenic to the diegetic. What these figures represent is the general movement of each chapter from a beginning which is diegetic to an ending which is scenic, with the diegetic opening to the chapter often coming on the heels of a scenic

\footnotetext{
${ }^{45}$ The following percentages reflect the results of a rudimentary analysis that was conducted by examining the first and last paragraphs of each chapter for signs of either mimesis or diegesis. In the analysis of chapter openings, mimetic paragraphs were determined to be those that either begin with mimetic quotation marks - such as the paragraph that opens Book IX, Chapter I, and begins with, "“The difficulty is,' Strether said to Madame de Vionnet [...]" (309) - or paragraphs that open with a brief diegetic passage (of less than one paragraph's length) that serves to set up a mimetic passage. On the other hand, diegetic paragraphs were determined to be those that fail to meet either of these criteria. In the analysis of chapter endings, paragraphs were analyzed on "mirrorimage" criteria; that is, mimetic paragraphs were determined to be those that either end with quotation marks, or a short summary of a previous mimetic passage, etc.
} 
ending in order to bring the narrative up to speed with respect to the details that have been elided during the chapter break.

Indeed, the novel itself is structured according to the same logic as its chapters. It begins with diegetic narrative: "Strether's first question, when he reached the hotel, was about his friend; yet on learning that Waymarsh was apparently not to arrive till evening he was not wholly disconcerted" (21). At the beginning there is no Waymarsh, hence no interlocutor, and hence no scene. The novel's closing chapter, however, ends on a different note: “[Maria Gostrey] sighed it at last all comically, all tragically, away. 'I can't indeed resist you.' / 'Then there we are!' said Strether" (470). This ending is decidedly scenic, especially given that the concluding scene occupies the last five pages of the novel. Thus, because the novel displays a consistent alternation between scene and summary, it can be said to represent a balanced ledger, with the gains in temporal unilinearity accrued by way of scenic representation being offset by the anachronistic synopses of a summarizing narrator. The final sentence - the mimetic "Then there we are!" - is reprised throughout the novel and can be thought of as connoting the novel's overall exchange economy, as it marks the various points at which the gains of the forward-moving scenic narrative catch up with the debits of a backward-moving narrative summary. It is thus conceivable that because the novel ends with this exclamation, it also ends with a balanced ledger.

But looking once again at James's comments on the narrative effects of the serial format, it is clear that the author does not view this format as promoting an exchange economy that exacts equitable payment for narrative boons. Rather, he regards its effects as entirely positive, figuring them as textual features that he can "exploit and enjoy" 
(James, "Preface to The Ambassadors" 10, emphasis added). The way in which the author exploits the serial format has already been discussed, and can be summarized by saying that he uses it to identify himself with aspects of the scenic structure that are able to represent analepses in spatio-temporal harmony with the forward thrust of the narrative text. It is logical, then, that his enjoyment of these effects would have to do with the alternate, diegetic mode that the scenic structure almost inevitably prompts: that of narrative summary. Thus in order to identify narrative voice in The Ambassadors as spatio-temporally unilinear, it is important to analyze the way in which the narrator counteracts, in his own enjoyable way, the anachronic effects of summary. In this sense, the enjoyment that the vocalizing narrator takes from his role as summarizer would be tantamount to the enjoyment that the heteronomous, glory-seeking James takes at being brought up on stage after a successful performance, all the while bowing to exclamations of "author, author, AUTHOR" (qtd. in Anesko 21). And it is thus significant that the enjoyable vocalization of summary often follows directly upon the close of a dramatic scene, just as the glory of authorial recognition follows the dramatic performance. In order to characterize this summarizing narrator in spatio-temporal terms it will be imperative to identify and analyze one of the indelible features of its vocalizations: the prevalence of the pluperfect verb tense.

The pluperfect (also known as the past perfect) is a verb tense that "designat[es] a time or action completed prior to some past point of time specified or implied" ("Pluperfect," def. A1). This tense is often employed by James, and is easily - although not exclusively - indicated by the presence of two consecutive "hads." A notable example of this propensity is on display in the following: "Waymarsh, who had had 
letters yesterday, had had them again to-day" (75). Perhaps a more useful example is the following: "[Strether] remembered the two absurdities that, if his presence of mind had failed, were the things that had had most to do with it" (119, emphasis in the original). In this latter example, the consecutive hads are used to refer to an event prior to a more recent past event, while the more recent event (albeit a conditional one in this example) is referred to with the single had. But while this tense may be viewed as an unmentionable feature of narration - that is, as the most natural way to refer to an event that has occurred prior to another antecedent event - critics have recognized it as being particularly prevalent in Jamesian narration: a phenomenon that begs explanation. ${ }^{46}$ For example, in an analysis of the pluperfect in James, Hisayoshi Watanabe aims to "show the unusual importance of the past perfect tense and retrospection in the late novels of Henry James" (165), stating that "The Ambassadors derives its unity from Strether's sustained consciousness" and that "it is when [this] consciousness becomes more sustained than usual that James employs the unusual technique" of the pluperfect (169). But how does the pluperfect tense work to represent a consciousness that is "more sustained than usual"? Watanabe explains this in the following: "What, then, concerned James was not the objective description of the actions but the impressions made on Strether's otherwise preoccupied mind by the external occurrences. Such a method may be said to produce a double image of what is going on outside Strether's mind and what is going on inside it" (169). For Watanabe, the past perfect tense indicates a past (or "outside") event that

\footnotetext{
${ }^{46} \mathrm{My}$ own investigation into the relationship between the pluperfect and the temporal coherence of The Ambassadors has been triggered by Adrian Poole's suggestive observations on the subject in the introduction to the Penguin Classics edition of the text (xxvii-xxviii). Importantly, though, Poole, like Watanabe, concludes that the pluperfect is used to bridge Strether's past and present thoughts, and not to maintain a centre of narrational deixis.
} 
Strether's consciousness is not primarily occupied with at the present moment of the narrative, but one that nonetheless has implications for his thoughts of the moment. In short, his argument is that these secondary, past, or outside events are represented in the past perfect tense in order to identify them as subject to Strether's cerebrations (that is, as opposed to being objective information supplied by an omniscient narrator to the ignorance of Strether), but also subordinate to Strether's immediate thoughts, which are represented using the simple past tense.

Watanabe also claims that while this verb tense often makes distinctions between present thoughts and other pertinent antecedent actions, it ultimately functions to blur distinctions between the two, representing past and present as subject to the leveling effects of an atemporal state of consciousness. He explains: "No small part of the focus on Strether's consciousness derives technically from the use of the past perfect tense so consistently that by the close of the novel we are scarcely aware whether a single passage of the pluperfect is anterior action or present action barely perceived by Strether" (Watanabe 170). Thus, whereas Darlene Harbour Unrue states that James used verb tenses consistently in an attempt to accurately "indicate shifts in time" (199), Watanabe claims that James often used the pluperfect to blur distinctions between past and present, thereby inciting ambiguity. Likewise, in his essay "Grammars of Time in Late James," Peter Rawlings writes: "at the logical, grammatical, and narrative levels, James was increasingly intrigued by the possibilities of complicating the present to include a

\footnotetext{
${ }^{47}$ While Unrue makes this claim, she determines the consistency of verb tense to be indicative of a system of spatio-temporal reference that is structured in relation to the protagonist's (specifically Isabelle Archer's) "point of view," and not according to the narrato-authorial subject's narrating act (199-200).
} 
tangible past and a conjecturable future" (274). ${ }^{48}$ In order to describe how James is able to achieve this effect through the use of verb tense, Rawlings echoes Watanabe; writing about the rhetoric of verb tense in James's late phase works, Rawlings states the following: "In what could serve as a plot summary of both "The Jolly Corner" and The Sense of the Past, [Otto] Jespersen contended that the 'double-sided character of the perfect' makes it difficult to keep up the sharp distinction between the idea of the present result of past events and the past events themselves" (281). Thus, for Rawlings, the pluperfect verb tense does important work in James, as it represents a conscious state in which past and present are conflated. In short, both Watanabe and Rawlings argue that the pluperfect tense serves to structure a system of deictic reference - one that is governed by the context of (what they refer to as) Strether's consciousness. They also argue that the verb tense serves to mimic the temporal ambiguity of consciousness by blurring distinctions between past events per se and past events as they relate to the present.

Implicit in these arguments is the idea that the Jamesian text is mono-subjective, the lone subject of the text being represented by the central consciousness or reflector character (in the case of The Ambassadors, the consciousness/character of Lambert Strether). Watanabe makes this evident when he writes, "The impression left by The Ambassadors is that of the hero's intense consciousness pervading the whole" $(170)$. And while Rawlings is not as explicit as Watanabe in identifying his critical object as a mono-subjective narrative text, that he treats it as such is evidenced by his inclination to

\footnotetext{
${ }^{48}$ For more on the relationship between James's use of verb tense and the temporal structure of his narratives, see Dimock.
} 
analyze the structure of each of his object texts solely in relation to its protagonist. ${ }^{49}$ In contrast, the current thesis deals with The Ambassadors as a text that is spatio-temporally structured in relation to two subjectivities: that of the protagonist Lambert Strether and that of the text's narrator. As such, it proposes a time scheme that operates in reference to two distinct, and yet related, temporal registers. Analyzing the text using this double structure may be thought of as promoting, rather than resolving, the text's ambiguity, given that it multiplies the potential referents for temporal indices. This is not the case, however. In the context of the bipartite schema developed in the current thesis, there is no ambiguity associated with what Watanabe and Rawlings refer to as the pluperfect verb tense's double reference to past and present. Rather than being a means of confusing past and present in a single expression, the pluperfect verb tense refers to antecedent events in a way that locates the narrator in distinct spatio-temporal reference to them. In this sense, the pluperfect disambiguates rather than conflates the narrative past and present. This effect is especially apparent when the pluperfect is used to narrate the summaries that open many of the novel's chapters. Because the norm of novelistic narration is the simple past tense, the past tense becomes the equivalent of the narrating subject's present tense. The Jamesian narrator thus uses the simple past tense to refer to narrative content that is, for lack of a better phrase, presently in front of him. But when the narrator is forced to narrate an event that has taken place at an antecedent point on this arc - that is, when he is obliged to bring the narrative up to speed by filling in the details elided by an

\footnotetext{
${ }^{49}$ For example, Rawlings structures his analysis of temporality in "The Jolly Corner" around the protagonist Spencer Brydon, while his analysis of The Sense of the Past is structured around its protagonist Ralph Pendrell. That is, if the consistent use of the pluperfect is meant to denote a structured system of deixis, Rawlings figures the Jamesian system as being structured in reference to the text's protagonist alone.
} 
elliptic chapter break - the narrator must use the pluperfect. The pluperfect tense identifies the elided events as antecedent and (as an attendant effect) locates the narrator relationally in the narrative present, thereby maintaining this subject's position along the unilinear narrative arc.

Leaving aside the topic of the pluperfect verb tense for the moment, it will help to analyze the opening sentences of a number of the novel's chapters in order to demonstrate the importance that the act of self-positioning has for the narrating subject. Immediately following the interval that divides the second and third books - that is, in the first sentence of Book III, Chapter I - the narrator states, "Strether told Waymarsh all about it that very evening, on their dining together at the hotel' (93, emphasis added). In this example, "it" is anaphoric, as it refers to the conversation that Strether was about to have with little Bilham at the end of the previous chapter - a conversation that was elided by the intervening chapter break. By referring to a conversation that was anticipated at the end of the last chapter as "it," and not as, for example, "his conversation with the man on the balcony," the new chapter makes a linguistic connection to the old chapter by way of anaphora, and the narrative thus maintains a linguistic flow from one chapter to the next. The first sentence also demonstrates the primacy of establishing a firm spatiotemporal point of reference in relation to the last chapter, as exhibited by the fact that the first sentence of the new chapter establishes the reference point with "that very evening" and "at the hotel." To give another example, the final sentence of Book IV, Chapter II ends in the midst of a scene, with Strether at this point in conversation with Maria Grostrey (155). After the close of the scene, the first sentence of the following chapter has the narrator state the following: "The Sunday of the next week was a wonderful day" 
(159). Once again, establishing the deictic reference point of the narrating instance is made a priority, as it is the narrator's first act following the chapter break. As a further example, at the end of Book V, Chapter III, while in conversation with Chad, Strether makes plans to meet Chad the next day, "at a quarter to five," at which point both men will make their way to Madame de Vionnet's (191). The chapter that follows the intervening chapter break then begins in this way: "It was quite by half-past five - after the two men had been together in Madame de Vionnet's drawing room not more than a dozen minutes - that Chad, with a look at his watch and then another at his hostess, said genially [...]" (195). In this example, not only does the narrator precisely identify the place and time of the narrative present - the latter to the very minute - but also Chad, "with a look at his watch," confirms the accuracy of the narrator's act of positioning as if to emphasize its importance. Additionally, after Book VI, Chapter I ends in the midst of a conversation between Strether and Madame de Vionnet, Chapter II begins with "In Chad's lovely home, however, one evening ten days later" (205). And after Book IX, Chapter III ends with a conversation between Strether and Mamie Pocock, the following chapter begins, "Strether occupied beside little Bilham, three evenings after his interview with Mamie Pocock, the same deep divan they had enjoyed together on the first occasion of our friend's meeting Madame de Vionnet [...]" (346). Such examples are endless, and generally operate according to the formula: " $\mathrm{X}$ days/hours after scene $\mathrm{Y}$ at $\mathrm{Z}$ place." And because these instances of spatio-temporal placement often occur in the first sentence of a chapter, they demonstrate the priority, for the narrator, of establishing a definite spatiotemporal point of deictic reference after ellipses of indeterminate length (such as those that occur during chapter breaks). 
But it is arguable that these spatio-temporal indices are meant to locate the protagonist - and not so much the narrator - at various points along a linear trajectory. And it is true, no doubt, that this is the case, given that there is strong correspondence between Strether's position along the geo-temporal narrative arc and the narrator's position along the spatio-temporal trajectory of narrative. But the predominance of the pluperfect verb tense indicates the degree to which these positionings are linguistic which identifies them as a means of pinpointing the position of a vocalizing subject, and not just the novel's protagonist. There is a notable passage in which the pluperfect tense is used to narrate internal analepses: the first paragraph of Book II, Chapter II. According to the narrator's overall tendency to establish the time and place of the narrative, the first sentence of the chapter explicitly identifies the narrative present: "Strether called, his second morning in Paris, on the bankers of the Rue Scribe to whom his letter of credit was addressed, and he made this visit attended by Waymarsh, in whose company he had crossed from London two days before" (74). As the end of the previous chapter was set in London, the elided story content represented by the chapter break includes, at the very least, Strether and Waymarsh's trip from London to Paris as well as the events of their first day in Paris. And while the chapter begins in the narrative present, it proceeds to narrate the events that were elided with the chapter break, particularly Strether and Waymarsh's first day in the French capital. Importantly, though, it conducts this task using the pluperfect tense, thereby preserving the narratorial present, which has as its point of reference the second day in Paris. While the narrator relates all the events of the second day in the simple past tense - for example, "Strether called, his second morning in Paris, on the bankers of the Rue Scribe" (emphasis added) 
- he narrates the events of the first day in the pluperfect: "[Strether and Waymarsh] had hastened to the Rue Scribe on the morrow of their arrival, but Strether had not then found the letters the hope of which prompted his errand" (74, emphasis added). Later on in this same paragraph, the narrator relates the events of the evening of the first day, again doing so in the pluperfect: "Waymarsh had accompanied him this time to the play, and the two men had walked together, as a first stage, from the Gymnase to the Café Riche, into the crowded 'terrace' of which establishment - the night, or rather the morning, for midnight had struck, being bland and populous - they had wedged themselves for refreshment" (75). Indeed all of the events of the first day are narrated using the pluperfect. But once again, in the second paragraph, when the subject of narration reverts to the events of the second day, the verb tense coincidentally reverts to the simple past tense: "This morning there were letters $[\ldots]$; so that, after a controlled impulse to go into them at the bank [...] he slipped them into the pocket of his loose grey overcoat with a sense of the felicity of carrying them off" (75, emphasis added to "slipped"). The opening paragraph of Book II, Chapter II is thus exemplary of the consistency with which the narrator uses the simple past and past perfect verb tenses to summarize the elided details of chapter breaks, using the former to indicate the narrative present and the latter to narrate internal analepses - or the narrative past.

Indeed, it is the consistency with which the narrator uses verb tense that not only positions Strether along the unilinear narrative arc, but also establishes and maintains the narrator's own position. By firmly establishing the present moment of narrational 
deixis $^{50}$ at the beginning of each chapter, and referring to any event that precedes this point using the pluperfect verb tense, the narrator is absolved of having to move back in time in order to summarize the pertinent story content which was elided with the chapter break. The narrator is thus absolved of having to pay for the temporal benefits of the scenic structure with a backward movement. The pluperfect tense allows him to refer to past events with one of the pluperfect's "hads" while maintaining a strong foothold in the narrative present with the other. In this sense, the occurrence of the narratorial pluperfect in The Ambassadors takes place predominantly after the close of the scenic curtain and draws attention to the narrato-authorial subject, just as the close of the curtain and the calls of the crowd conjure the presence of the playwright. The pluperfect thus signals the enjoyment component of James's exploitation and enjoyment of the serial format. It also charts the narrator's unilinear spatio-temporal course, and serves as evidence of this narrator's possession of the bourgeois virtue of sustained attention. But as this verb tense is the "past" perfect it is not able to resolve another of the problems posed to the narrator who wishes to travel the narrative arc: the demands of prolepsis. Like narrative summary, prolepsis forces the narrator to deviate from the spatio-temporal present in order to narrate a future event; rather than forcing a jump back in time, prolepsis demands a jump forward. And because the narrator of The Ambassadors has been figured

${ }^{50}$ Phelan and Rabinowitz define the concept of narrational deixis in the following: "the function of certain words (demonstrative pronouns, definite articles, temporal adverbs) to locate referents in place and time relative to the speaker's location. In a narrative utterance such as 'I realized that this apple was now better than that orange,' 'this' and 'that' have the deictic function of indicating that the apple is closer to the ' $I$ ' than the orange, while 'now' has the deictic function of indicating both some change over time and the speaker's current realization" (543). The system of deixis described in this chapter is only different from the one described here in that it is a means of consistently locating the speaker in spatio-temporal relation to a geo-temporally-situated referent, and not vice versa. 
throughout the thesis as tracing Strether's plodding geo-temporal course, instances of narrative prolepsis in The Ambassadors serve to complicate these conclusions, as such instances indicate discordance between the narrative present (as indicated by the location of Strether's body) and the narratorial point of deictic reference. And while prolepsis is not, in a strictly linguistic sense, different from analepsis, ${ }^{51}$ from the standpoint of subjective verisimilitude, prolepsis and analepsis differ in the sense that a narrating subject can be imagined to have the power to narrate a past event from memory, but he or she cannot be imagined to have perceptual access to future events.

Although the novel does not altogether forgo the use of proleptic passages, it does employ such passages sparingly; in fact, there are only two such passages in the book. Significantly, the primary such passage is embedded in a scene that is set in a theatre, and narrates Strether's initial reactions after originally meeting Chad in a box at the ThéâtreFrancais: "He was to know afterwards, in the watches of the night, that nothing would have been more open to him than after a minute or two to propose to Chad to seek with him the refuge of the lobby" (119). The prolepsis is triggered with the "afterwards" of the above: the narrator relates Strether's thoughts after he has left the theatre while the first narrative is still situated in the theatrical setting. The narrator even particularizes the proleptic setting, identifying it as nocturnal with "in the watches of the night." Importantly, though, the proleptic setting is not particularized to the extent of bearing a strict relation to the setting of the first narrative: the Théâtre-Francais. Lying within the first arrondissement, or in the very heart of Paris, the location of the Théâtre-Francais is distinct; but where is this posterior scene of meditation? While it is presumable that the

\footnotetext{
${ }^{51}$ Hypothetically, the proleptic counterpart of the analeptic past-perfect verb tense would be the future perfect tense.
} 
"night" referred to here is the one immediately following the performance, the fuzzy descriptors do not make this fact obvious, nor do they identify the location of the proleptic setting. Thus, unlike the deictic chapter beginnings, which explicitly emphasize the narrator's spatio-temporal location with the formula " $\mathrm{X}$ days/hours after scene $\mathrm{Y}$ at $\mathrm{Z}$ place," this instance of prolepsis refers only to an ambiguous and indeterminate setting. This lack of particularity allows the immediate setting of the theatre to trump the proleptic nocturnal setting, and allows the narrative to be proleptic without really being proleptic - that is, without really moving to a distinct future place-time. This passage can thus be seen as a minor hiccup, and not one that poses a significant challenge to the narrative's, or the narrator's, spatio-temporal unilinearity.

The second instance of narrative prolepsis occurs in the famous Lambinet scene, specifically in the second chapter of a scene that spans Chapters III and IV of Book XI. ${ }^{52}$ This scene has been extensively analyzed, and is noteworthy for being set in a French country village that is described as bearing an uncanny resemblance to an unidentified painting by Lambinet:

The oblong gilt frame disposed its enclosing lines; the poplars and willows, the reeds and river - a river of which [Strether] didn't know, and didn't want to know, the name - fell into a composition, full of felicity, within them; the sky was silver and turquoise and varnish; the village on the left was white and the church on the right was grey; it was all there, in short - it was what he wanted: it was Tremont Street, it was France, it was Lambinet. Moreover, he was freely walking about in it. (411)

\footnotetext{
${ }^{52}$ For other analyses of the Lambinet scene, see Beidler, Cuddy-Keane, and Wilson.
} 
This scene is also notable because its setting is not disclosed - it is set in an anonymous French village "not nearer Paris than an hour's run" on the train (411) - and is described as being set in the painting itself. Furthermore, the exact painting is never identified, but is rather described as a "small Lambinet that had charmed [Strether], long years before at a Boston dealer's and that he had quite absurdly never forgotten" (411). This retrospective quality is just one of the features that serve to dislocate the scene from the rest of the narrative. Another is the fact that the scene is not identified in strict spatial relation to Paris. A third is elicited in the opening sentence of the chapter: "He had taken a train a few days after this from a station - as well as to a station - selected almost at random" (410, emphasis in the original). While the other chapter openings are explicit in maintaining the spatio-temporal link across chapter breaks, this one deliberately obscures its relationship to the previous chapter, as it ambiguously refers to the temporal space dividing the two as "a few days" and refers to the spatial distance between them in wholly negative and indeterminate terms - that is, as an undisclosed distance from Paris. With respect to the narrating instance, the scene is also ekphrastic, given that the narration of it is akin to the narration of a work of art such as that of Aeneas's shield in The Aeneid..$^{33}$ In this sense, the scene is a satellite or appendage that bears an indistinct relation to the primary narrative arc; it is a space that exists independently of the primary narrative, as it is framed as a pseudo-anonymous artwork existing in an indefinite place and time.

The proleptic passage that is embedded within this scene occurs in Book XI, Chapter IV, after Strether happens upon Chad and Madame de Vionnet at the Cheval

\footnotetext{
${ }^{53}$ See Book VIII of The Aeneid.
} 
Blanc. Because the chance meeting comes as such a shock to Strether, upsetting as it does so many of the premises upon which he has executed, up to this point, his mission in Paris, it gives him plenty to reconsider - too much, in fact, to consider within the span of his dining with Chad and Madame de Vionnet after their meeting. The occasion thus demands another midnight vigil, which is described in the following:

What it all came to had been that fiction and fable were, inevitably, in the air, and not as a simple term of comparison, but as a result of things said; also that they were blinking it, all round, and that they yet needn't, so much as that, have blinked it - though indeed if they hadn't Strether didn't quite see what else they could have done. Strether didn't quite see that even at an hour or two past midnight, even when he had, at his hotel, for a long time, without light and without undressing, sat back on his bedroom sofa and stared straight before him. (423, emphasis in the original)

As opposed to the other, earlier instance of proleptic narrative, this one explicitly identifies the place and time of the prolepsis: it is not an undisclosed hour, but rather "an hour or two past midnight" of the same day; and it is not an undisclosed place, but is his room in his hotel in Paris. While this difference would appear to mark this second instance of embedded prolepsis as an uncharacteristic leap from one point on the narrative arc to another (and then back again), it is interesting that it does not, in fact, alter the unilinearity of the narrative. This is because the present instance of the narrative - the point from which the narrative moves - is not linked in an exact way to the first narrative. It is rather free-floating, much like the balloon of romance from the preface to The American: 
The balloon of experience is in fact of course tied to the earth, and under that necessity we swing, thanks to a rope of remarkable length, in the more or less commodious car of the imagination; but it is by the rope we know where we are, and from the moment the cable is cut we are at large and unrelated: we only swing apart from the globe - though remaining as exhilarated, naturally, as we like, especially when all goes well. The art of the romancer is, "for the fun of it," insidiously to cut the cable, to cut it without our detecting him. (The Art 34)

The Lambinet scene is thus such an instance of the romantic - or perhaps, more aptly put, it is an instance of the fantastic. The ambiguity of place and time with which the scene opens is a signal that the cable connecting it to the spatio-temporal sequence structuring the first narrative has been cut. And the chance meeting between Strether and his counterparts does nothing to ameliorate the fantastic and unreal qualities of the scene, given that the meeting is described as being "as queer as fiction, as farce" (419). Nor does their subsequent conversation during dinner, as this conversation is said to only add to the level of unreality: "What it all came to had been that fiction and fable were, inevitably, in the air, and not as a simple term of comparison, but as the result of things said" (423). But with the proleptic passage, the cable is re-tied, connecting the satellite or the "fable" that is "in the air" - to the unilinear narrative arc by way of the distinct identification of the place and time of Strether's later midnight reveries. The scene is thus a piece of ekphrasis tethered to the first narrative at this single point of proleptic contact. Therefore, in this instance, prolepsis does not disrupt the unilinearity of the narrative arc but instead serves as a connection between this scene and the primary 
narrative: a rope that connects the fantastic scene to reality - or the more verisimilar system of spatio-temporal organization.

But while this instance of prolepsis serves to re-tether an errant sequence of narrative to the first narrative, it may be wondered why the author chose to cut the rope in the first place. That is, why did the narrato-authorial subject - an individual who takes pride at being able to stretch a thread of continuous duration through the text - choose to efface himself at this point? A thorough analysis of this deviation is beyond the scope of this thesis; but it seems that the thread is cut in order to show that Strether is acting for the first time, in the Lambinet scene, of his own volition. If his initial reason for leaving America was to serve as Mrs. Newsome's ambassador, and if he was subsequently - and almost seamlessly - passed off to Madame de Vionnet and Chad's camp in order to act as their ambassador, then the entire narrative represents Strether's actions as those performed on behalf of others. ${ }^{54}$ Accordingly, Strether's time in Chester, London, and his first days in Paris become strongly associated with Mrs. Newsome's will, while the latter days in Paris get associated with the determining agents of Chad and Madame de Vionnet. And because these places become so strongly associated with the purposes of others, the geo-linear sequence that they form gets identified as a chain of determinism. Thus, in order to act on his own behalf, and thereby bring to an end this chain of

\footnotetext{
${ }^{54}$ Julie Rivkin also sees a connection between Strether's role as a delegate for the novel's European and American contingents and his role as the novelist's delegate: "Employing Strether as ambassador for Mrs. Newsome, James invites us to see Strether's role as a substitute or delegate for another absent authority, James himself; further, by having Strether invoke a 'logic' of delegation that governs his own actions and permits him no distinct profits from his mission James implies the existence of a similar textual logic that regulates the novel's representational system, central to which is Strether's role as authorial stand-in or delegate" (819).
} 
determinism, Strether must find a different place - a place of his own - in which to act. ${ }^{55}$ And in order to give Strether a place in which to do so, James must cut his own narrative thread, which has as a basis Strether's geo-temporal path. That the Lambinet scene represents such a temporary cessation of the linear narrative sequence is argued by Sarah Wilson, who refers to the scene as indicating a "non-narrative moment:" "The nonnarrative moment serves as a momentary disruption in the comfortable and familiar progression of the narrative. The jolt serves to question the reader's established patterns of proceeding through the text" (514). About the non-narrative moment in the Lambinet scene specifically, Wilson writes that the break in the narrative sequence that occurs at this point serves as a formal indication that Strether is here not acting - as he has been in the passages conveyed using linear narrative - on the behalf of others: "In the nonnarrative moment at the Cheval Blanc, Strether perceives that he, as an ambassador, is lost, along with his national errand" (517). It is thus because the spatio-temporal sequence has become so metonymically associated with the chain of determinism that the narrato-authorial agent has to cut the cable, thereby forgoing, at the beginning of the Lambinet scene, the use of the formula " $\mathrm{X}$ days/hours after scene $\mathrm{Y}$ at $\mathrm{Z}$ place." But while this indicates a break in the thread, the narrato-authorial subject expresses his impatience at reconnecting it, as he does not wait until the beginning of a new scene to do so; the formula that signifies the narrator's position of deictic reference is rather used in advance of the onset of a new chapter. The proleptic passage thus re-tethers the floating

\footnotetext{
${ }^{55}$ If Strether has suffered under the burden of having to apply his overactive imagination toward a relatively simple objective, and if the singular interests of both his American and Parisian associates have come to be imbued in their respective places of residence, the setting of the Lambinet scene - with its numerous disinterested suggestions for the imagination - is Strether's place, in that it is a place in which his imagination and his surroundings may exist in a sort of symbiotic harmony.
} 
narrative sequence to the first narrative; it also denotes that the thread has perforce been cut, and that the narrato-authorial agent cannot wait to retie it. Thus, if the narratoauthorial subject is forced to sever the thread at the beginning of the Lambinet scene, he is quick to reconnect it in order to reassure us that he is still attending.

\section{Conclusions}

While one of the specific objectives of this thesis has been to develop and execute a methodology that is able to overcome the inertia that has served to preempt narratological analyses of Jamesian voice, a more general purpose has been the evocation of the bi-subjective nature of the Jamesian text. The failure on the part of past critics to recognize the text's bi-subjective nature is signaled by the too-easy conflation of the subjects of Strether and James. One critic who reads the Jamesian text in this way is Martha Nussbaum. In her work, Nussbaum analyzes the subject of attention in James from the perspective of the moral philosopher. She describes the type of attention on display in James as "moral attention," defining this term as a "fine development of our human capabilities to see and feel and judge, an ability to miss less, to be responsible to more" (164). But Nussbaum ascribes this moral quality to James by first identifying Strether as its possessor, after which conflating, with a sort of sleight of hand, the novel's protagonist and author. Nussbaum displays this inclination toward subjective conflation in the following:

By showing us the novel's world (more or less) through Strether's eyes, indeed by making it next to impossible to distinguish those eyes from the author's eyes [...] James makes a case for the moral significance of the novelist's (and the reader's) 
"sense of life," for the vigilant and responsive imagination that cares for everyone in the situation and refuses the injunction of Woollett to "simplify" for the sake of purity and safety. The very sentences are Strether's, straining toward perceptual rightness in the midst of wonderful puzzling mysteries. (184-5, emphasis in the original)

Here, Nussbaum identifies Strether and James as interchangeable subjects. In a subsequent passage, she praises these interchangeable subjects for displaying the ascendant moral position indicated by "a posture of agency that is porous and susceptible of influence" (180). In other words, Nussbaum sees represented in the text two synonymous subjects who are willing to sacrifice (to a radical degree) their own interests for the greater moral good. But in doing so, Nussbaum links the subjects of James and Strether in a way that precludes the idea that, for example, James manipulated the latter's characteristics in order to further his own interests as a literary producer. Based on the conclusions of this thesis - and contra Nussbaum - James does not reflect or echo Strether's disinterest and willingness to sacrifice everything to an ethics of alterity; rather, the text identifies James as a literary agent who is situated in a highly interested struggle within the literary field, and who manipulates the text's protagonist - along with the conventions of the novelistic genre - according to his position-taking strategy.

However, these conclusions are not meant to suggest that the text is devoid of material for the moral philosopher; they rather imply that acknowledgment of the bisubjective textual dynamic has the potential to open up new ways of understanding the moral quality of the Jamesian text. It has been argued in this thesis that the focalizing subject of The Ambassadors regulates the spatial relationship between the narrative and 
the story, while a narrating subject exploits this relationship in order to stress his own discursive unilinearity and construct for himself the heteronomous virtue of sustained voluntary attention. But this is not to say that the virtue of sustained voluntary attention has to be regarded as a fetishized virtue only; because attentiveness has been recognized by Nussbaum and other scholars to have a moral value, ${ }^{56}$ future analysis that recognizes the bi-subjective nature of the text may be conducted in order to elucidate the morality of James's unilinear narratorial discourse. For example, such further work might distinguish between the protagonist and the narrato-authorial subject in order to draw connections between the text's narrator, narratee and reader - possibly using a cognitivist paradigm to do so - in order to determine how this value is encoded in, and disseminated by, the text. ${ }^{57}$ But this type of analysis would not have to forfeit the image of James as a literary agent in exchange for a thoroughly moral image of the author. Indeed, such a study could figure the novelist's morality as inextricably entwined in the highly competitive production culture in which James was situated. It is thus hoped that this thesis has laid some of the groundwork for such a contextualized analysis of a moral quality of The Ambassadors.

Further on the topic of general intentions, this thesis has attempted to develop a nuanced means of contextualizing James. It has expressed the idea that the process of contextualization does not involve addressing an either-or question, with James having to

\footnotetext{
${ }^{56}$ See also Nicholas Davey's essay “On the Polity of Experience: Toward a Hermeneutics of Attentiveness."

${ }^{57}$ Such a paradigm might be structured on "a pragmatic and cognitive framework that takes into consideration the world-model, values and norms, and conceptual information previously existing in the mind of reader or critic, and the interplay between textual and extratextual information" (Nünning, "Reconceptualizing" 97-98). See also Li for a cognitivist analysis of narrative deixis.
} 
be either a socially ambivalent aesthete or an acutely perceptive and astute social commentator. Such a binary conception of James is evoked in the preface to the recently published critical anthology Henry James in Context:

Long misread as a novelist conspicuously lacking in historical consciousness, James has often been viewed - sometimes attacked - as detached from, and uninterested in, the social, political and material realities of his time. But as recent criticism has increasingly discerned, and as I hope this volume will help to demonstrate, James is an essential modern novelist precisely insofar as he was acutely, if anxiously, responsive not only to his era's changing attitudes toward gender, sexuality, class and ethnicity, but also to changing conditions of literary production and reception, to the rise of consumerism and mass culture, and to the emergence of new technologies and media, of new apprehensions of time and space - responsive, that is, in the fullest sense to the material and historical conditions that in his own time determined new, specifically modern forms of experience and subjectivity. (McWhirter xix)

While there is an inclination to represent James as an author acting with a singular either aesthetic or social - objective, this thesis has attempted to represent an author who was writing with a great degree of linguistic and structural control, but writing in response to a number of impulses, the plurality of which is indicated, in part, by the Bourdieuian concepts of heteronomy and autonomy. Accordingly, questions of Jamesian aesthetics and social consciousness are not incommensurable. Indeed, it is what McWhirter refers to as James's response to "changing conditions of literary production and reception" that not only effects his identity as a disengaged and socially ambivalent 
writer, but also his "new apprehensions of time and space" and "specifically modern forms of experience and subjectivity." It is hoped that the thesis has demonstrated that the socially aloof and socially responsive James are not mutually exclusive subjects, but are rather related and textually identifiable, as indicated by the expression and interaction in his texts of both the autonomous and heteronomous principles.

Finally, it must be noted that this thesis has not had the scope to address an important topic: the implications of the preceding analysis for narratology as a theoretical field. While Ansgar Nünning coins a term that classifies the type of analysis conducted in this thesis - a term that evokes some of its theoretical implications by putting the thesis in relation to other approaches to narratology - it is clear that his term is not entirely sufficient in this regard. Nünning uses the term "applied cultural narratology" to designate the class of narratological studies that puts "the analytical toolkit developed by narratology in the service of context-sensitive interpretations of novels" (353). And while this thesis has applied the narratological concepts (or "tools") developed by Genette in order to conduct a context-sensitive reading of The Ambassadors, the term "applied cultural narratology" is somewhat imprecise in describing the thesis as a whole. This is because it does not suggest the uncanny relationship that arises when narratological theory is "applied" to James's The Ambassadors - a proto-narratological text that has served as the source of much narratological theory. Rather than reflect the discrete division between theory and text that is implied by the term "applied cultural narratology," the narratological analysis of a contextualized Jamesian text impels the analyst to reevaluate his or her narratological concepts as new conclusions are drawn about the source-text under investigation. This puts the analyst in a reciprocal position in 
which the narratological terms that are applied to the text have to be continually qualified as the analysis proceeds. And while the introduction to the thesis briefly touched on the dizzying dynamics of such a process with a description of the homologies between the nineteenth-century literary field and the twentieth-century field of academic research, the thesis as a whole has not sufficiently addressed this topic, but has rather set the stage for further research into the reciprocal dynamic engendered by a context-sensitive narratological analysis of a proto-narratological text. That said, the thesis has suggested ways of conducting such further, more properly theoretical, research. By arguing in the first chapter that the personal and political interests of twentieth-century narrative theorists affected the development of theoretical concepts, the thesis attempted to compare and contrast narratological concepts with their literary sources, thereby confronting the complicated relationship between narratological and proto-narratological texts. Certainly, an approach that attempts to further contextualize both the literary source-text of these narratological concepts, along with the mode by which such concepts were developed and refined by subsequent theorists, would exist as an exemplary means of addressing this uncanny relationship. It was also mentioned in the introduction, as well as demonstrated throughout the course of the thesis, that another way of addressing this uncanny relationship is to maintain a fluid and contingent notion of one's chosen narratological terms and categories. As Genette himself writes in the conclusion to his introduction to Narrative Discourse, "We will be careful, however, not to hypostatize these terms, not to convert into substance what is each time merely a matter of relationships" (32). Maintaining the contingency of these terms is conducive to an approach to narratological research that treats narratology as a relationship between texts 
and contexts rather than as a refinement or consecration of narratological terms on the basis of specious, unspecified, and vaguely Platonic assumptions. In summary, while the thesis has positioned itself more as a "reading" of James's The Ambassadors and less as a theoretical treatise, it has suggested ways of conducting the latter type of work in the future. 


\section{Works Cited}

Abrams, M. H., and Geoffrey Galt Harpham. A Glossary of Literary Terms. Toronto, ON: Thomson Wadsworth, 2005.

Aczel, Richard. "Hearing Voices in Narrative Texts." New Literary History. 29.3 (1998): 467-500.

Agnew, Jean-Christophe. "The Consuming Vision of Henry James." The Culture of Consumption: Critical Essays in American History, 1880-1980. New York, NY: Pantheon Books, 1983. 65-100.

Amoros, J.A.A. "Henry James, Percy Lubbock, and Beyond: A Critique of the AngloAmerican Conception of Narrative Point of View." Studio Neophilica. 66.1 (1994): 47-57.

Anesko, Michael. 'Friction with the Market': Henry James and the Profession of Authorship. New York, NY: Oxford UP, 1986.

Arata, Stephen. “On Not Paying Attention.” Victorian Studies. 46.2 (2004): 193-205.

Bal, Mieke. Narratology: An Introduction to the Theory of Narrative. $2^{\text {nd }}$ ed. Toronto, ON: U of Toronto P, 1997.

Basic, Sonja. "From James's Figures to Genette's Figures: Point of View and Narratology.” Revue Francaise d'Etudes Americaines. 8.17 (1983): 201-15.

Beidler, Paul G. "The Ambassadors: The Oblong Gilt Frame." Frames in James.

Victoria, BC: English Literary Studies (U of Victoria), 1993. 74-92.

Besant, Sir Walter. "The Art of Fiction." The Art of Fiction: Sir Walter Besant and Henry James. Boston, MA: Cupples, Upham \& Co., 1885. 1-48.

Booth, Wayne C. The Rhetoric of Fiction. $2^{\text {nd }}$ Ed. Chicago: U of Chicago P, 1983. 
Bosanquet, Theodora. Henry James at Work. London: The Hogarth Press, 1924.

Bourdieu, Pierre. The Field of Cultural Production: Essays on Art and Literature. Ed.

Randall Johnson. New York, NY: Columbia UP, 1993.

Chatman, Seymour. The Later Style of Henry James. Oxford: Basil Blackwell, 1972.

Cuddy-Keane, Melba. "Narration, Navigation, and Non-Conscious Thought:

Neuroscientific and Literary Approaches to the Thinking Body." University of Toronto Quarterly. 79.2 (2010): 680-701.

Culler, Jonathan. "Foreword to Narrative Discourse." Genette 7-13.

Dames, Nicholas. "Reverie, Sensation, Effect: Novelistic Attention and Stendhal's De l'amour." Narrative. 10.1 (2002): 47-68.

Davey, Nicholas. "On the Polity of Experience: Towards a Hermeneutics of Attentiveness." Renascence: Essays on Values in Literature. 56.4 (2004): 217-34.

Deane, Bradley. The Making of the Victorian Novelist: Anxieties of Authorship in the Mass Market. New York, NY: Routledge, 2003.

Dimock, Wai Chee. "Subjunctive Time: Henry James's Possible Wars." Narrative. 17.3 (2009): 242-54.

Dubois, Jacques. "Pierre Bourdieu and Literature." Trans. Meaghan Emery and Pamela Sing. SubStance. 29.3 (2000): 84-102.

Edel, Leon. The Life of Henry James. 5 vols. New York, NY: Avon Books, 1978. Fernandez-Duque, Diego, and Mark L. Johnson. "Attention Metaphors: How Metaphors Guide the Cognitive Psychology of Attention." Cognitive Science. 23.1 (1999): 83-116. 
Fludernik, Monika. "Histories of Narrative Theory (II): From Structuralism to Present." Phelan and Rabinowitz 36-59.

Friedman, Norman. "Point of View in Fiction: The Development of a Critical Concept." Publication of the Modern Language Association. 20.5 (1955): 1160-84.

Genette, Gérard. "Introduction to the Paratext." Trans. Marie Maclean. New Literary History. 22.2 (1991): 261-72.

---. Narrative Discourse: An Essay in Method. Trans. Jane E. Lewin. Ithaca, NY: Cornell UP, 1980.

Griffin, Susan M. The Historical Eye: The Texture of the Visual in Late James. Boston, MA: Northeastern UP, 1991.

Guirand, Félix, ed. New Larousse Encyclopedia of Mythology. Toronto, ON: The Hamlyn Publishing Group Ltd., 1959.

Hagner, Michael. "Toward a History of Attention in Culture and Science." Modern Language Notes. 118.3 (2003): 670-87.

Hale, Dorothy J. "Wayne Booth, Gerard Genette, and Roland Barthes." Social Formalism: The Novel in Theory from Henry James to the Present. Stanford, CA: Stanford UP, 1998. 64-112.

Herman, David. "Histories of Narrative Theory (I): A Genealogy of Early Developments." Phelan and Rabinowitz 19-35.

Hocks, Richard A. "Perspective, Method, and Aesthetic Assumptions." Henry James and Pragmatistic Thought: A Study in the Relationship Between William James and the Literary Art of Henry James. Chapel Hill, NC: The U of North Carolina P, 1974. 3-14. 
Hutchison, Hazel. “James's Spectacles: Distorted Vision in The Ambassadors.” The Henry James Review. 26.1 (2005): 39-51.

Izzo, Donatella. "More Lessons from the Master: Henry James and the Literary Field." Izzo and Martinez 67-88.

---, and Carlo Martinez, ed. Revisionary Interventions into Henry James. Naples, IT:

Università degli Studi di Napoli l'Orientale, 2008.

Jahn, Manfred. "Frames, Preferences, and the Reading of Third-Person Narratives:

Towards a Cognitive Narratology." Poetics Today. 18.4 (1997): 441-68.

James, Henry. The Ambassadors. Toronto, ON: Penguin Books, 2008.

---. "The Art of Fiction." The Norton Anthology of Theory and Criticism. Ed. Vincent B.

Leitch, et al. New York: W.W. Norton and Co., 2001. 855-69.

---. The Art of the Novel. Ed. Richard Blackmur. New York: C. Scribner's Sons, 1962.

---. "The Figure in the Carpet." Embarrassments. Freeport, NY: Books for Libraries, 1970. 3-82.

---. Henry James: Letters. Vol. IV. Ed. Leon Edel. Cambridge, MA: The Belknap Press, 1984.

---. What Maisie Knew. Markham, ON: Penguin Books, 1966.

James, William. "Attention.” The Principles of Psychology. Vol. I. New York, NY: Dover Publications, Inc., 1890. 402-58.

Kafalenos, Emma. "Lingering along the Narrative Path: Extended Functions in Kafka and Henry James." Narrative. 3.2 (1995): 117-38.

Kreilkamp, Ivan. "The Best Man of All': Mythologies of the Storyteller.” Voice and the Victorian Storyteller. New York, NY: Cambridge UP, 2005. 1-34. 
Kurnick, David. "What Does Jamesian Style Want?" The Henry James Review. 28.3 (2007): 213-22.

Lambert, Anthony. Switzerland Without a Car. Guilford, CT: The Globe Pequot Press, 2009.

Laufer, Matt. "'You Can't Run and Read It': Melville's Search for the Right Reader." Leviathan: A Journal of Melville Studies. 6.2 (2004): 17-38.

Li, Naicong, and David A. Zobin. "Discourse Continuity and Perspective Taking." Deixis in Narrative: A Cognitive Science Perspective. Ed. Judith F. Duchan, et al. Hillsdale, NJ: Lawrence Erlbaum Associates, 1995. 287-307.

Lubbock, Percy. The Craft of Fiction. New York, NY: Viking Press, 1957.

McWhirter, David, ed. Henry James in Context. New York, NY: Cambridge UP, 2010.

---, ed. Henry James's New York Edition: The Construction of Authorship. Stanford, CA:

Stanford UP, 1995.

Meissner, Colin. "Talking About Money: Art and Commerce in America." Rawlings, Palgrave Advances 263-82.

Miller, J. Hillis. "Henry James and 'Focalization,' or Why James Loves Gyp." Phelan and Rabinowitz 124-35.

Moi, Toril. "The Challenge of the Particular Case: Bourdieu's Sociology of Culture and Literary Criticism." Modern Language Quarterly. 58.4 (1997): 497-508.

Nieragden, Göran. "Focalization and Narration: Theoretical and Terminological Refinements." Poetics Today. 23.4 (2002): 685-97.

Nünning, Ansgar F. "Reconceptualizing Unreliable Narration: Synthesizing Cognitive and Rhetorical Approaches." Phelan and Rabinowitz 89-107. 
---. "Where Historiographic Metafiction and Narratology Meet: Towards an Applied Cultural Narratology." Style. 38.3 (2004): 352-75.

Nussbaum, Martha C. "Perceptive Equilibrium: Literary Theory and Ethical Theory." Love's Knowledge: Essays on Philosophy and Literature. New York, NY: Oxford UP, 1990. 168-94.

Pearson, John H. The Prefaces of Henry James: Framing the Modern Reader. University Park, PA: Pennsylvania State UP, 1997.

Phelan, James, and Peter J. Rabinowitz, ed. A Companion to Narrative Theory. Malden, MA: Blackwell Publishing, 2008.

"Pluperfect." The Shorter Oxford English Dictionary. $5^{\text {th }}$ ed. New York, NY: Oxford UP, 2002.

Poole, Adrian. Introduction. The Ambassadors. By Henry James. Toronto, ON: Penguin Books, 2008. xv-xxxv.

Poovey, Mary. "Forgotten Writers, Neglected Histories: Charles Reade and the Nineteenth-Century Transformation of the British Literary Field." English Language History. 71.2 (2004): 433-53.

Prince, Gerald. A Dictionary of Narratology. Revised ed. Lincoln, NE: U of Nebraska P, 2003.

Rawlings, Peter. "Grammars of Time in Late James." The Modern Language Review. 98.2 (2003): 273-84.

---. "Narratives of Theory and Theories of Narrative: Point of View and Centres of Consciousness.” Rawlings, Palgrave Advances 35-58. 
---, ed. Palgrave Advances in Henry James Studies. New York, NY: Palgrave Macmillan, 2007.

Ribot, T.A. The Psychology of Attention. New York, NY: The Open Court Publishing Co., 1890.

Rimmon[-Kennan], Shlomith. The Concept of Ambiguity - the Example of James. Chicago, IL: Chicago UP, 1977.

Ringuette, Dana. “'This Matter of Attention and Discrimination': Henry James's Essays on Speech, Manners, and American Women." The Henry James Review. 31.2 (2010): 125-41.

Rivkin, Julie. "The Logic of Delegation in The Ambassadors." PMLA. 101.5 (1986): 81931.

Rose, Jonathan. "Was Capitalism Good for Victorian Literature?" Victorian Studies. 46.3 (2004): 489-501.

Ryan, Judith. "Henry James." The Vanishing Subject: Early Psychology and Literary Modernism. Chicago, IL: The University of Chicago Press, 1991.75-88.

Seligson, Judith. "Visual Intertextuality: Drawing Comparisons in The Wings of the Dove." The Henry James Review. 31.1 (2010): 68-84.

Seltzer, Mark. Henry James and the Art of Power. Ithaca: Cornell UP, 1984.

Shand, Alexander F. "Attention and Will: A Study in Involuntary Action." Mind.4.16 (1895): 450-71.

Shen, Dan. "Narrative, Reality, and Narrator as Construct: Reflections on Genette's 'Narrating." Narrative. 9.2 (2001): 123-9. 
Simon, Linda. The Critical Reception of Henry James: Creating a Master. Rochester, NY: Camden House, 2007.

Slaughter, J. W. "The Fluctuations of Attention in Some of Their Psychological Relations." The American Journal of Psychology. 12.3 (1901): 313-34.

Smit, David W. The Language of a Master: Theories of Style in the Late Writing of Henry James. Carbondale, IL: Southern Illinois UP, 1988.

Spiller, Gustav. "The Dynamics of Attention." Mind. 10.40 (1901): 498-524.

Sternberg, Meir. "Spatio-Temporal Art and the Other Henry James: The Case of The Tragic Muse." Poetics Today. 5.4 (1984): 775-830.

Stougaard-Nielsen, Jakob. "Attention! Henry James and the Distracted Reader." The Henry James Review. 31.1 (2010): 14-20.

Tintner, Adeline R. Henry James and the Lust of the Eyes: Thirteen Artists in his Work. Baton Rouge, LA: Louisiana State UP, 1993.

Todorov, Tzvetan. The Poetics of Prose. Trans. Richard Howard. Ithaca, NY: Cornell U. P., 1977.

Unrue, Darlene Harbour. "The Occult Metaphor as Technique in The Portrait of a Lady." The Henry James Review. 2.3 (1981): 199-203.

Vastolo, Manuela. "In the Cage of Class." Izzo and Martinez 43-65.

Walton, Priscilla L. "Victorian England (1870-1890)." McWhirter, Henry James in Context 26-36.

Watanabe, Hisayoshi. "Past Perfect Retrospection in the Style of Henry James." American Literature. 34.2 (1962): 165-81. 
Wilson, Sarah. “Americanness Becomes Modernism in James's The Ambassadors.” Studies in the Novel. 36.4 (2004): 509-32. 